\title{
MISSING THE FOREST FOR THE TROLLS
}

\author{
Mark A. Lemley* $\mathcal{E}$ A. Douglas Melamed**
}

Patent trolls are increasingly blamed for the growing costs of patent litigation and seemingly excessive damages awards and patent royalties. There is much to support these allegations. Trolls now account for a majority of all patent assertions, win both larger judgments and larger settlements than do firms that practice patents, and do so despite complaints and some evidence that they assert weak patents. Nonetheless, we think the focus on trolls obscures more complex and fundamental problems with the patent system. There are at least three different troll business models that have varying effects on the patent system. Based on our review of the economics of patent assertions, we find that patent assertions by practicing entities can create problems that, while sometimes different from, are at least as costly as those created by trolls. Many of the problems associated with trolls are in fact problems that stem from the disaggregation of complementary patents into multiple hands. Our review takes us beyond labels and the search for "bad actors" and leads us to focus instead on aspects of the patent system that give rise to the problems, and on changes in patent law that will ameliorate them. These changes include updating standards for issuing patents and patent remedies, implementing measures to reduce abusive patent litigation, and heightened legal scrutiny of disaggregation of patent portfolios. We conclude that trolls are a symptom of larger flaws in the patent system and that those who have focused on trolls have, in effect, been missing the forest for the trolls.

INTRODUCTION

I. TROLLS AND THE ANTI-TROLL BACKLASH .......................................2121

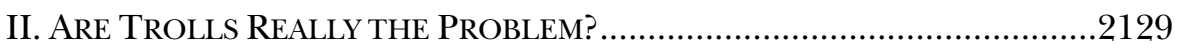

A. Payments, Cross-Licenses, and Opportunity Costs ...................2129

1. Opportunity Costs .........................................................2130

a. There Is No Free Lunch .............................................2130

* William H. Neukom Professor of Law at Stanford Law School and Partner at Durie Tangri LLP.

** Senior Vice President and General Counsel of Intel Corporation. Our views are our own and not those of our employers or clients. The authors thank Bill Baer, Joe Bankman, Michael Burstein, Colleen Chien, Marcus Cole, Peter Detkin, Craig Fratrik, Lee Greenfield, Rose Hagan, Louis Kaplow, Dan Klarman, Christopher Leslie, Rob Merges, Fiona Scott Morton, Mark Popofsky, Michael Risch, Ben Roin, Steve Rodgers, Bruce Sewell, Carl Shapiro, Steve Shavell, Ted Sichelman, Tim Simcoe, Henry Smith, Kelce Wilson, and participants at the IP Scholars Conference and workshops at Stanford Law School and Harvard Law School for very helpful comments on an earlier draft, and Steve Salop for inspiring in earlier conversations some of the ideas in this paper. (C 2013 Mark A. Lemley \& A. Douglas Melamed. 
b. The Money Illusion .2134

2. Why Assertions by Practicing Entities Can Be More Costly .2139

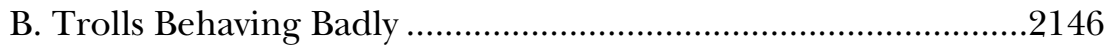

1. Royalty Stacking 2146

2. Patent Aggregation 2153

a. Do Trolls Aggregate Patents More than Practicing Entities? .2154

b. Is Patent Aggregation Bad? ......................................2155

3. Litigation Costs .2161

4. Improper or Aggressive Patent Assertion Tactics ...............2163

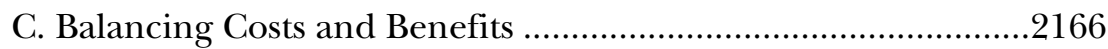

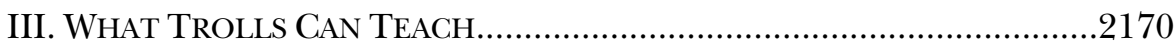

CONCLUSION 2180

\section{INTRODUCTION}

Patent trolls-patent owners whose primary business is collecting money from others that allegedly infringe their patents-are on everyone's mind. Complaints that trolls are perverting the patent system or interfering with innovation are legion. NPR has run feature stories on the problems with trolls. ${ }^{1}$ The New York Times and the Wall Street Journal have run front-page articles about them. ${ }^{2}$ The Federal Trade Commission has issued reports recommending action against trolls. ${ }^{3}$ Congress passed patent reform legislation that was designed in part to deal with the problem of trolls ${ }^{4}$ and is currently considering new legislation that is intended to apply specifically to patent trolls. ${ }^{5}$ Companies, engineers, lawyers, and scholars have spent enormous amounts of time complaining about

1. E.g., This American Life: When Patents Attack!, NPR (July 22, 2011), available at http://www.thisamericanlife.org/radio-archives/episode/441/when-patents-attack (transcript on file with the Columbia Law Review).

2. E.g., Charles Duhigg \& Steve Lohr, The Patent, Used as a Sword, N.Y. Times (Oct. 7, 2012), http://www.nytimes.com/2012/10/08/technology/patent-wars-among-techgiants-can-stifle-competition.html (on file with the Columbia Law Review); Ashby Jones, Patent 'Troll' Tactics Spread, Wall St. J. (July 8, 2012, 8:46 PM), http://online.wsj.com/ article/SB10001424052702303292204577514782932390996.html (on file with the Columbia Law Review).

3. FTC, The Evolving IP Marketplace: Aligning Patent Notice and Remedies with Competition (2011), available at http://www.ftc.gov/os/2011/03/110307patentreport.pdf (on file with the Columbia Law Review).

4. Leahy-Smith America Invents Act (AIA), Pub. L. No. 112-29, 125 Stat. 284 (2011) (codified in scattered sections of 35 U.S.C.).

5. Saving High-Tech Innovators from Egregious Legal Disputes Act of 2013 (SHIELD Act), H.R. 845, 113th Cong. (2013). 
trolls. ${ }^{6}$ There are publicly traded companies devoted to fighting patent trolls, ${ }^{7}$ and there are even companies devoted to figuring out what patents particular trolls own. ${ }^{8}$ Concern about patent trolls has percolated up to the very highest levels, and in February 2013 President Obama went out of his way to condemn them in a public address. ${ }^{9}$ A recent academic study calculates that trolls cost society approximately $\$ 30$ billion per year ${ }^{10}$ and have cost a total of $\$ 500$ billion over the past twenty years. ${ }^{11}$ The harshest criticism is reserved for companies like Intellectual Ventures, sometimes called a "super-troll" or "troll aggregator," for gathering and asserting or licensing tens of thousands of patents. ${ }^{12}$

Trolls are a significant feature of the patent system. They account for a large and growing number of suits, now a majority of all patent assertions in the country and an even higher percentage in the information technology (IT) industry. ${ }^{13}$ They win both larger judgments and larger

6. To take just one example, DITTO.com is raising money to combat patent troll lawsuits against it and offering an "I Beat Trolls" T-shirt to those who help it. Kate Endress, Save Startup, DITTO.com, from Patent Trolls, Indiegogo, http://www.indiegogo.com/ projects/save-startup-ditto-com-from-patent-trolls (on file with the Columbia Law Review) (last visited Oct. 10, 2013).

7. They include RPX Corp. and Allied Security Trust. See, e.g., Andrei Hagiu \& David B. Yoffie, The New Patent Intermediaries: Platforms, Defensive Aggregators, and Super-Aggregators, J. Econ. Persp., Winter 2013, at 45, 56-58 (describing RPX and Allied Security Trust as "defensive aggregators").

8. See, e.g., Jack Ellis, Intellectual Ventures Investigation to Go Ahead Without Indiegogo Funds, Intell. Asset Mgmt. (IAM) Mag. Blog (Dec. 4, 2012), http://www.iammagazine.com/blog/Detail.aspx?g=62b7ad3d-e360-41db-aa59-4c7b6f3bfefe (on file with the Columbia Law Review) (identifying IP Checkups as company devoted to unearthing subsidiaries owned by patent troll Intellectual Ventures).

9. Obama Says Patent Reform Needs to Go Farther, Reuters (Feb. 14, 2013, 8:52 PM), http:/ / www.reuters.com/article/2013/02/15/us-obama-patent-idUSBRE91E03320130215 (on file with the Columbia Law Review).

10. James Bessen \& Michael J. Meurer, The Direct Costs from NPE Disputes, 99 Cornell L. Rev. (forthcoming 2014) (manuscript at 3) [hereinafter Bessen \& Meurer, Direct Costs], available at http://www.bu.edu/law/faculty/scholarship/workingpapers/ documents/BessenJ-MeurerM062512revised7-2013.pdf (on file with the Columbia Law Review). For criticism of this study and its methodology, see David L. Schwartz \& Jay P. Kesan, Analyzing the Role of Non-Practicing Entities in the Patent System, 99 Cornell L. Rev. (forthcoming 2014), available at http://papers.ssrn.com/abstract=2117421 (on file with the Columbia Law Review).

11. James Bessen et al., The Private and Social Costs of Patent Trolls 17 (Bos. Univ. Sch. of Law Working Paper No. 11-45, 2011), available at http://ssrn.com/ abstract=1930272 (on file with the Columbia Law Review).

12. E.g., Jeff John Roberts, How Chicago Is Beating Silicon Valley at the Patent Game, paidContent (Mar. 25, 2012, 9:05 PM), http://paidcontent.org/2012/03/25/419how-chicago-is-beating-silicon-valley-at-the-patent-game/ (on file with the Columbia Law Review) (referring to Intellectual Ventures as "super-troll"). For academic discussion of Intellectual Ventures, see, for example, Tom Ewing \& Robin Feldman, The Giants Among Us, Stan. Tech. L. Rev., Jan. 9, 2012, at 1, 3-15, http://stlr.stanford.edu/pdf/feldmangiants-among-us.pdf (on file with the Columbia Law Review).

13. Because trolls tended to sue multiple defendants in a single suit, at least until that became much more difficult with the passage of the AIA in 2011, it is important to focus 
settlements than do "practicing entities"-those that practice patents and are not principally in the business of collecting money from others that practice them. ${ }^{14}$ And trolls do so despite complaints that they often assert weak patents, ${ }^{15}$ and despite some evidence that troll-owned patents are more likely than other patents to lose in court. ${ }^{16}$

Nonetheless, we think the focus on patent trolls obscures a more complex set of challenges confronting the patent system. In this Article, we make three points about the problems commonly associated with trolls. First, patent trolls are not a unitary phenomenon. We see at least three different troll business models developing, and those models have different effects on the patent system. Second, patent assertions by practicing entities can create just as many problems as assertions by patent trolls. The nature of many industries obscures some of the costs of those assertions, but that does not mean they are cost-free. In addition, practicing entities are increasingly engaging in "patent privateering," in which product-producing companies take on many of the attributes of

on the number of assertions (that is, the number of defendants sued), not just the number of suits. RPX data reported by Chien show that trolls accounted for $62 \%$ of suits and $59 \%$ of assertions in 2012. Colleen Chien, Patent Trolls by the Numbers (Santa Clara Univ. Sch. of Law, Legal Studies Research Paper No. 08-13, 2013), available at http://papers. ssrn.com/abstract=2233041 (on file with the Columbia Law Review). Similarly, Feldman, Ewing, and Jeruss find that "patent monetization entities filed $58.7 \%$ of the patent lawsuits in 2012. This is a sharp rise from 2007, when patent monetization entities filed only $24.6 \%$ of patent infringement litigations." Robin Feldman, Tom Ewing \& Sara Jeruss, The AIA 500 Expanded: The Effects of Patent Monetization Entities, 18 UCLA J.L. \& Tech. (forthcoming 2013) (manuscript at 7), available at http://ssrn.com/abstract=2247195 (on file with the Columbia Law Review).

14. The 2012 PricewaterhouseCoopers study of patent litigation found that patent trolls won damages awards almost twice as high on average as those won by practicing entities. PwC, 2012 Patent Litigation Study 5 (2012), available at http://www.pwc.com/ en_US/us/forensic-services/publications/assets/2012-patent-litigation-study.pdf (on file with the Columbia Law Review).

15. See Robert P. Merges, The Trouble with Trolls: Innovation, Rent-Seeking, and Patent Law Reform, 24 Berkeley Tech. L.J. 1583, 1603-04 (2009) (discussing allegations that trolls file suits on weaker patents). But see Shawn P. Miller, Patent "Trolls": RentSeeking Parasites or Innovation-Facilitating Middlemen? 12 (Apr. 26, 2010) (unpublished manuscript), available at http://papers.ssrn.com/abstract=1885538 (on file with the Columbia Law Review) (finding trolls generally litigate higher-quality patents than practicing entities).

16. See John R. Allison et al., Patent Quality and Settlement Among Repeat Patent Litigants, 99 Geo. L.J. 677, 694 (2011) [hereinafter Allison et al., Patent Quality] (finding troll suits were much less likely than nontroll suits to result in ruling for patentee). See also Shawn P. Miller, Where's the Innovation: An Analysis of the Quantity and Qualities of Anticipated and Obvious Patents, 18 Va. J.L. \& Tech. 1, 29-31, 49-50 (2013) (finding troll patents are more likely to be invalidated on prior art grounds). But see Shawn P. Miller, What's the Connection Between Repeat Litigation and Patent Quality? A (Partial) Defense of the Most Litigated Patents, 16 Stan. Tech. L. Rev. 313, 334, 336 (2013) [hereinafter Miller, Most Litigated Patents], http://stlr.stanford.edu/pdf/mostlitigatedpatents.pdf (on file with the Columbia Law Review) (using different measurement than Allison et al. and finding troll-owned most-litigated patents are more successful than other patents). 
trolls. Put differently, while trolls exploit problems with the patent system, they are not the only ones that do so. Third, many of the problems associated with trolls are in fact problems that stem from the disaggregation of complementary patents (patents that cover technologies used together in the same products) into too many different hands. That in turn suggests that aggregators might be reducing, not worsening, these problems (though, as we will see, the overall effects are ambiguous) and that "patent privateers" that spin off patents in order for others to assert them might make things worse. For this reason, patent reformers and antitrust authorities should worry less about aggregation of patent rights and more about disaggregation of those rights, sometimes accomplished by spinning them out to others.

Understanding the economics of patent assertions by both trolls and practicing entities allows us to move beyond labels and the search for "bad actors" and to focus instead on aspects of the patent system itself that give rise to the problems and on specific, objectionable conduct in which both trolls and practicing entities sometimes engage. Patent trolls alone are not the problem; they are a symptom of larger problems with the patent system. Treating the symptom will not solve the problems. In a very real sense, critics have been missing the forest for the trolls. Exposing the larger problems allows us to contemplate changes in patent law that will actually tackle the underlying pathologies of the patent system and the abusive conduct they enable.

In Part I, we discuss the rise of patent trolls and the anti-troll backlash. We identify different sorts of patent troll business models and how they overlap with the business models of practicing entities. In Part II, we consider the economics of patent assertion by both trolls and practicing entities and explore whether, and, if so, under what circumstances, trolls impose greater costs on technology users than do practicing entities that hold patents. In Part III, we argue that we should pay more attention to the underlying features of the patent system that unduly burden technology users and make patent trolls profitable, and focus less on identifying and weeding out particular companies that take advantage of those underlying features.

\section{TROLLS AND THE ANTI-TROLL BACKLASH}

The patent system is designed to encourage innovation by giving inventors the exclusive right to their technologies for a limited period of time. In the classical model of the patent system, patent litigation is brought by a company that invented something and sells it in the marketplace against competitors that copy the new technology. ${ }^{17}$ But patent law does not require proof that the defendant copied from the

17. For discussion of the classic story and its theoretical justification, see, for example, Mark A. Lemley, The Economics of Improvement in Intellectual Property Law, 75 Tex. L. Rev. 989, 991-95 (1997). 
plaintiff ${ }^{18}$ or even that the plaintiff has made a product at all, ${ }^{19}$ and indeed the vast majority of patent lawsuits today are filed against parties that independently developed the allegedly infringing technology. ${ }^{20}$ Nor does patent law require that only the inventor enforce the patent. Patents can be bought and sold, ${ }^{21}$ and they can be enforced by whichever party owns them at the time. The inventor is thus often not the entity filing suit. Patent trolls typically, but not always, acquire their patents from others. $^{22}$

Not too many years ago, Colleen Chien classified patent suits into general categories, including "sport of kings" cases, in which large companies battle it out for supremacy; "David v. Goliath" cases, in which an individual, usually an inventor, sues a large company accused of profiting from his invention; "limited stakes" cases, in which small/medium companies fight each other; "predation" cases, in which patents are used to squelch a small upstart competitor; and "NPE" cases, in which patent trolls sue the (generally large) companies that make products. ${ }^{23}$ In that paper, she estimated that $19 \%$ of patent lawsuits were filed by patent trolls. ${ }^{24}$ That number understated the role of trolls because it focused on the number of suits, not the number of defendants, and trolls tend to sue many more defendants per suit than do practicing entities. ${ }^{25}$ It also

18. See, e.g., Samson Vermont, Independent Invention as a Defense to Patent Infringement, 105 Mich. L. Rev. 475, 478-80 (2006) (explaining patent holder may hold independent inventors liable for infringement and arguing for "independent invention" defense).

19. See, e.g., Christopher A. Cotropia, The Folly of Early Filing in Patent Law, 61 Hastings L.J. 65, 72-75 (2009) (describing ease of meeting "reduction to practice" requirement).

20. Christopher A. Cotropia \& Mark A. Lemley, Copying in Patent Law, 87 N.C. L. Rev. 1421, 1451 (2009) (noting copying is established in only approximately $2 \%$ of patent infringement cases in study, and even less often in IT industry).

21. 35 U.S.C. $\$ 261$ (2006).

22. See, e.g., John R. Allison et al., Extreme Value or Trolls on Top? The Characteristics of the Most-Litigated Patents, 158 U. Pa. L. Rev. 1, 20-25 (2009) [hereinafter Allison et al., Trolls on Top] (finding many patents are assigned before any lawsuits are filed, and "trolls hold a significant share of the most important patents"); Kimberly A. Moore, Populism and Patents, 82 N.Y.U. L. Rev. 69, 108 n.99 (2007) (finding many litigated patents are purchased by plaintiff before suit).

23. Colleen V. Chien, Of Trolls, Davids, Goliaths, and Kings: Narratives and Evidence in the Litigation of High-Tech Patents, 87 N.C. L. Rev. 1571, 1577-90 (2009) [hereinafter Chien, Of Trolls].

24. Id. at 1603.

25. See Allison et al., Patent Quality, supra note 16, at 700-04 (finding troll suits name more defendants than do nontroll suits). Patent suits in the Eastern District of Texas are overwhelmingly brought by trolls, see Colleen Chien, PowerPoint: NPEs in the Northern District of California (2012) [hereinafter Chien, NPEs] (on file with the Columbia Law Review), and suits in this district name many more defendants per case than suits elsewhere. James C. Pistorino \& Susan J. Crane, Perkins Coie, 2011 Trends in Patent Case Filings: Eastern District of Texas Continues to Lead Until America Invents Act Is 
underestimated the role of trolls by excluding "David v. Goliath" cases even where the "David" was not practicing the patent. Counting defendants and excluding David v. Goliath cases, Chien found that 28\% of all assertions were made by patent trolls as recently as five years ago. ${ }^{26}$ But the number of troll suits has grown rapidly in recent years. Today, patent trolls account for more than half of all patent suits. ${ }^{27}$

Patent trolls are particularly common in the software industry. ${ }^{28}$ Software and internet patents are nearly ten times as likely to be asserted as other types of patents, ${ }^{29}$ in part because there are so many software patents and in part for other reasons discussed in Part II. Empirical evidence suggests that the most-litigated patents, which are responsible for more than $10 \%$ of all patent assertions ${ }^{30}$ are overwhelmingly software patents and that cases involving the most-litigated patents are (1) overwhelmingly filed by patent trolls and (2) overwhelmingly unsuccessful when litigated to judgment. ${ }^{31}$

Signed 2-3 (2012), available at http://www.perkinscoie.com/files/upload/PL_12_ 03PistorinoArticle.pdf (on file with the Columbia Law Review).

26. Chien, Of Trolls, supra note 23, at 1604.

27. See supra note 13 (discussing data on number of troll suits); see also Chien, NPEs, supra note 25 (noting dramatic increase in number of patent troll suits in 2012, to $55 \%$ of all cases and $91 \%$ of cases in Eastern District of Texas); cf. John R. Allison et al., Patent Litigation and the Internet, Stan. Tech. L. Rev., Feb. 14, 2012, at 1, 6 [hereinafter Allison et al., Internet], http://stlr.stanford.edu/pdf/allison-patent-litigation.pdf (on file with the Columbia Law Review) (finding small entities, which includes most patent trolls, were much more likely than large entities to enforce internet patents). Enactment of the AIA in late 2011 made it harder for a troll to sue multiple defendants in the same case and thus encouraged trolls thereafter to file more separate cases in order to target the same number of defendants. See Feldman, Ewing \& Jeruss, supra note 13 (manuscript at 7, 56) (suggesting reduction in defendants sued by patent trolls may be due to AIA's changes in joinder rules, which require trolls to file more suits).

Trolls are also behind claims against more than $50 \%$ of the defendants in the International Trade Commission (ITC), even though the ITC nominally requires that there be a domestic industry protected by the asserted patent. Colleen V. Chien \& Mark A. Lemley, Patent Holdup, the ITC, and the Public Interest, 98 Cornell L. Rev. 1, 14-15, 17 (2012).

28. Portions of this paragraph are adapted from Mark A. Lemley, Software Patents and the Return of Functional Claiming, 2013 Wis. L. Rev. (forthcoming) [hereinafter Lemley, Return of Functional Claiming], available at http://papers.ssrn.com/ abstract $=2117302$ (on file with the Columbia Law Review).

29. See, e.g., Allison et al., Internet, supra note 27, at 4 ("Internet patents and their two subtypes were litigated at a far higher rate than [noninternet patents]-they were between 7.5 and 9.5 times more likely to end up in infringement litigation ....").

30. Allison et al., Trolls on Top, supra note 22, at 24 (finding 106 most-litigated patents accounted for $14 \%$ of all patent assertions during period studied).

31. Allison et al., Patent Quality, supra note 16, at 687 \& tbl.3, 688, 692 \& fig.2, 69596; see also Allison et al., Internet, supra note 27 , at $27 \&$ tbl.9 (finding win rate of owners of internet patents was extremely low, roughly $3 \%$ ). Using a more limited definition of outcomes and combining multiple suits into a single outcome, Miller finds that the mostlitigated patents generally are more likely to win on validity than once-litigated patents, 
Despite evidence of failure in court, the troll business model seems to be not only surviving, but thriving. ${ }^{32}$ As the troll phenomenon has grown, it has also evolved. In Chien's more recent work, she found that trolls were increasingly targeting startups, not just large companies. ${ }^{33}$

Criticism of patent trolls is widespread. ${ }^{34}$ There is widespread belief that trolls impose greater costs on technology users and society as a whole than do practicing entities, and that they provide little social benefit to offset those costs. ${ }^{35}$ According to one estimate noted above, trolls cost the economy $\$ 500$ billion over the last twenty years, mostly in the IT industry. ${ }^{36}$ Other reports suggest that patent trolls inhibit innovation at the firms they sue. ${ }^{37}$

The excess costs imposed directly by trolls could come in a variety of forms: (1) damages/royalties for patents that, while valid, would otherwise not be enforced; (2) damages/royalties for infringing invalid patents; (3) damages/royalties in excess of the value of the patented technology, even assuming the patent is valid and infringed; and (4) litigation and related costs in excess of those that would otherwise be incurred. The first of these might not be objectionable as a matter of policy because, as we discuss below, monetization of patents that would otherwise not be enforced might increase the rewards to inventors who

but that repeatedly asserted software patents are not. Miller, Most Litigated Patents, supra note 16 , at $344-45$.

32. See Erik Hovenkamp, Predatory Patent Litigation 3 (Aug. 5, 2013) [hereinafter Hovenkamp, Predatory Patent Litigation] (unpublished manuscript), available at http://papers.ssrn.com/abstract=2308115 (on file with the Columbia Law Review) (arguing trolls may aggressively pursue even litigation likely to be unsuccessful as part of strategy for monetizing weak patents).

33. See Colleen V. Chien, Startups and Patent Trolls, 17 Stan. Tech. L. Rev. (forthcoming 2014) (manuscript at 1-2) [hereinafter Chien, Startups], available at http://papers.ssrn.com/abstract=2146251 (on file with the Columbia Law Review) ("Although large companies tend to dominate patent headlines, most unique defendants to troll suits are small.").

34. For a more detailed discussion of a number of common complaints against patent trolls, see infra Part II.

35. Trolls, like practicing entities that enforce patents, assert patents against businesses and individuals that they allege infringe the asserted patents by using technologies claimed by the patents. These companies and individuals, referred to here as "technology users," might use the allegedly patented technologies in research and development, manufacturing processes, and the sale or use of services or products that embody those technologies.

36. Bessen et al., supra note 11, at 17 . While a patent market that includes substantial technology transfer is probably a desirable thing, there is no reason to believe patent trolls generally engage in much legitimate technology transfer. See generally Merges, supra note 15 (arguing patent troll participation in secondary market for patents does not serve technological innovation).

37. See, e.g., Catherine Tucker, Patent Trolls and Technology Diffusion 28-29 (Mar. 26, 2013) (unpublished manuscript), available at http://ssrn.com/abstract $=1976593$ (on file with the Columbia Law Review) (concluding decrease of innovation in healthcare IT could be attributed to fear of patent litigation). 
are themselves unable to monetize their patents or commercialize their inventions..$^{38}$ The others seem plainly undesirable because they impose on technology users either increased transaction costs or costs in excess of the value of the patentable inventions claimed by the asserted patents.

Such excess costs would impose public harm beyond the harm to technology users. By increasing the costs of using technology, they would both transfer wealth from technology users to patent holders and create deadweight, welfare-reducing loss by decreasing the use of patented technologies and the manufacture and sale of products using patented technologies. In addition, by increasing the costs of using patented technologies, they would reduce the use of those technologies in research and development $(\mathrm{R} \& \mathrm{D})$ and in follow-on inventions and thereby reduce innovation.

In theory, these harms could be offset by increased rewards to inventors of patented technologies and thus increased incentives for invention in furtherance of the purpose of the patent laws. As we suggest below, however, there is little evidence that trolls significantly increase rewards to inventors. ${ }^{39}$ Moreover, desirable incentives for invention in furtherance of the purpose of the patent laws are not increased by payments for invalid patents or in excess of the value of the patented technology, or by increased litigation costs. ${ }^{40}$

Assessing whether, and, if so, how, trolls impose excess costs on technology users requires a clear understanding of both the trolls' business models and those of practicing entities. The common, shorthand reference to "trolls" and "practicing entities" obscures the ambiguities in those terms and the fact that both terms encompass a variety of entities that differ in the scope of their activities and in the ways they use patents.

Allison et al. have identified several different sorts of trolls or, as they are sometimes called, nonpracticing entities (NPEs). ${ }^{41}$ Some, including

38. See infra notes 147-151 and accompanying text (discussing arguments for and against desirability of monetizing otherwise-overlooked patents).

39. Cf. infra note 148 (noting only small portion of money collected by trolls goes to inventors); infra note 208 and accompanying text (noting most troll suits are against independent inventors).

40. Cf. Christopher R. Leslie, Patents of Damocles, 83 Ind. L.J. 133, 133 (2008) (asserting patents are intended to foster innovation, and fraudulently obtained patents injure competition with no corresponding benefit).

41. Types of trolls include: Entity Class 1 (acquired patents), Entity Class 2 (university heritage or tie), Entity Class 3 (failed startup), Entity Class 4 (corporate heritage), Entity Class 5 (individual inventor started company), Entity Class 6 (university/ government/NGO), Entity Class 7 (startup, pre-product), Entity Class 8 (product company), Entity Class 9 (individual), Entity Class 10 (undetermined), Entity Class 11 (industry consortium), and Entity Class 12 (IP subsidiary of product company). Allison et al., Trolls on Top, supra note 22, at 10 tbl.1. Colleen Chien defines what she calls "patentassertion entities" as those companies primarily in the business of enforcing patents for licensing fees. Colleen V. Chien, From Arms Race to Marketplace: The Complex Patent 
most universities, are engaged in research and genuine efforts at technology transfer. ${ }^{42}$ But even among companies that make a business out of threatening to sue others for patent infringement, three distinct business models are developing. Individual entities might at various times employ any of these models.

The first and most traditional troll model is a company that owns a patent and hopes to strike it big in court. These trolls think they have a patent that reads on a significant area of technology, and it is very important to them that their patent be held valid and infringed. They are interested in a big jury award against one or more entrenched players in the industry. We refer to them as "lottery-ticket" trolls because they are playing an uncertain shot at a big payout. ${ }^{43}$

Second, a growing number of trolls are interested in quick, low-value settlements for a variety of patents. ${ }^{44}$ These plaintiffs do not want to go to trial and are thus not particularly interested in the quality of their patents or whether they are infringed. Rather, they rely on the high cost of patent litigation-a median of $\$ 5.5$ million for substantial cases that go to trial, by one recent estimate ${ }^{45}$ - to induce the parties they sue to settle for small amounts of money rather than pay millions to their lawyers. We call this group the "bottom-feeder" trolls. While no individual patent suit in this model makes a lot of money, the model can be lucrative because patent holders can sue lots of defendants on the same patent, forcing multiple settlements, and because there are lots of patents to be had for very little money as long as quality is unimportant. Colleen Chien has found that $90 \%$ of patent troll suits result in total defendant expenditures of less than $\$ 10$ million, including attorneys' fees, suggesting that most patent trolls fall into the bottom-feeder category. ${ }^{46}$

A final group of trolls is engaged in the business of patent aggregation. These "patent aggregators" collect many patents-sometimes tens of thousands. ${ }^{47}$ They demand royalties to license the portfolio and

Ecosystem and Its Implications for the Patent System, 62 Hastings L.J. 297, 300 (2010) [hereinafter Chien, Arms Race]. Reasonable people can disagree over which of these categories should be regarded as trolls.

42. See Mark A. Lemley, Are Universities Patent Trolls?, 18 Fordham Intell. Prop. Media \& Ent. L.J. 611 (2008) [hereinafter Lemley, Universities] (no).

43. For a (successful) example, see Microsoft Corp. v. i4i Ltd. P'ship, 131 S. Ct. 2238, 2252-53 (2011), which affirmed i4i's judgment against Microsoft.

44. Chien, Startups, supra note 33 (manuscript at 15) (“'Bottom feeder' trolls make demands of many companies at once in order to get nuisance settlements.").

45. Am. Intellectual Prop. Law Ass'n, Report of the Economic Survey 34 (2013) [hereinafter AIPLA, Report] (finding patent infringement suits with more than $\$ 25$ million at stake cost median amount of $\$ 5.5$ million per side in legal fees in 2013).

46. Colleen Chien, PowerPoint: Patent Assertion Entities (2012) [hereinafter Chien, Patent Assertion Entities], available at http://ssrn.com/abstract=2187314 (on file with the Columbia Law Review).

47. While it is difficult to identify patent holdings, particularly when these aggregators have numerous subsidiaries, Ewing and Feldman estimate that, for example, 
threaten to sue those that do not pay. ${ }^{48}$ Scale is critical to this model. Patent aggregators depend on sheer numbers rather than the quality and value of any given patent. Their scale often enables them to license without litigation because defendants are reluctant to challenge an entire portfolio of patents. ${ }^{49}$ The patent aggregation model depends on patent intensity in an industry; it works because the patent aggregator has so many patents that read on a particular target that a challenge to the validity of the patents makes little sense. Successful patent aggregators can generate a great deal of licensing revenue with little or no actual litigation, though they may have to file some suits from time to time just to show they are serious about enforcement. ${ }^{50}$

The variety of patent troll business models has a number of implications. First, the bottom feeders and patent aggregators can often fly under the radar from the perspective of the courts. Patent aggregators file very few suits relative to their impact, and bottom feeders file lots of suits but settle virtually all of them. Both significantly influence the business of patent litigation, but they do so in a way that is largely invisible to an appellate court and therefore does not influence that court's legal decisions. Thus, despite the prevalence of bottom-feeder suits, the Federal Circuit seemed surprised to learn about the bottomfeeder business model in a recent case. The court agreed with the district court's determination that the model had "indicia of extortion," and clearly thought the patentee's behavior was an outlier. ${ }^{51}$ In fact, however, the only thing unusual about that case was that the defendant was willing

Intellectual Ventures has a worldwide portfolio of patents and patent applications of 30,000-60,000 and at least 8,000 U.S. patents; Transpacific IP Ltd. holds over 3,000 U.S. patents; and Round Rock holds over 3,400 U.S. patents. Ewing \& Feldman, supra note 12, at 5, 16-17; cf. Chien, Arms Race, supra note 41, at 328-30 (comparing size of massaggregator trolls to many much smaller trolls).

48. Cf. Ewing \& Feldman, supra note 12, at 12-15 (documenting behavior of one such patent aggregator, Intellectual Ventures).

49. For early discussion of the role of patent portfolios in inhibiting litigation, see Gideon Parchomovsky \& R. Polk Wagner, Patent Portfolios, 154 U. Pa. L. Rev. 1, 34-35 (2005) (asserting portfolios decrease litigation by increasing chance portfolio holder will have infringement claim or counterclaim, and increasing stakes).

50. Lex Machina reports thirty-six lawsuits involving Intellectual Ventures as of October 1, 2013. Search Results, Lex Machina, http://www.lexmachina.com (search "Intellectual Ventures" under "Parties" tab; add all parties; limit dates to up to September 30, 2013) (on file with the Columbia Law Review) (last visited Oct. 26, 2013); see, e.g., Intellectual Ventures I LLC v. Check Point Software Techs. Ltd., No. 10-cv-1067-LPS, 2013 WL 2291947 (D. Del. Apr. 5, 2013) (dismissing case filed by Intellectual Ventures due to stipulation); see also Ewing \& Feldman, supra note 12, at 13 (noting enforcement may make licensees more compliant with demands). Some are declaratory judgment actions, and some appear to involve the same dispute.

51. Eon-Net LP v. Flagstar Bancorp, 653 F.3d 1314, 1326-27 (Fed. Cir. 2011) (finding patent suit was without merit). 
to fight it all the way to appeal. Most patent assertions are resolved without litigation or by settlement of litigation. ${ }^{52}$

Second, the three types of patent trolls differ greatly in their attitude toward the patents they assert. Lottery-ticket trolls bet their business on winning and winning big. They are interested in enforcing patents they think a court will hold valid and construe broadly, and they usually want to enforce their patents against multiple defendants. They need to be very careful in their litigation strategies because a patent that is found to be invalid in a final determination in one litigation is invalid thereafter for all purposes. ${ }^{53}$ Bottom feeders and patent aggregators, by contrast, are much less concerned with the validity and scope of any given patent-bottom feeders because they plan to settle before validity and infringement are determined, and aggregators because they always have another patent to replace one a court invalidates. As a result, lotteryticket trolls are generally more risk-averse than bottom feeders and patent aggregators. ${ }^{54}$

The apparent indifference to patent quality has itself spurred criticism of trolls, particularly the patent aggregators. The logic of the criticism is straightforward: These patent trolls do not themselves invent anything but buy patents from others, and, because they do not even care whether the patents they buy are any good, they impose substantial costs on innovative companies without contributing anything to the world. Hence, some critics say, the problem with the patent system is trolls asserting too many patents and, in particular, too many weak patents. ${ }^{55}$

Practicing entities that assert patents are also far from unitary. A typology of practicing-entity plaintiffs might include (a) patentees that hope to exclude competitors from the market in order to be the only entities practicing the patented technologies, the classic use of patents; (b) patentees that hope to disadvantage their competitors by raising rivals' costs, for instance by forcing competitors to use older or less efficient technology or imposing excessive licensing fees upon them; and (c) patentees that simply want to monetize their patents. The first two, strategic uses of patent assertions might either protect the patent holder's existing businesses or facilitate its entry into new businesses. The patent holder might or might not use money generated by the latter two to fund other lines of business.

52. See Allison et al., Patent Quality, supra note 16, at 689 (finding approximately 85-90\% of filed cases are settled before decision).

53. See Blonder-Tongue Labs., Inc. v. Univ. of Ill. Found., 402 U.S. 313, 349-50 (1971) (allowing estoppel to block suit for infringement of patent previously held invalid).

54. See Kelce S. Wilson \& Claudia Tapia Garcia, The Three Classes of Patent Usage, 46 les Nouvelles 283, 288 (2011) (noting "NPEs can be significantly more risk-tolerant in their selection of patents to litigate" because they do not need to protect product investment).

55. See, e.g., Hovenkamp, Predatory Patent Litigation, supra note 32, at 3 (explaining why trolls might assert weak patents). 
As explained below, there are also differing relationships between the patents that are practiced by practicing entities and the patents they assert against others, directly or indirectly. ${ }^{56}$ In some instances, practicing entities assert against others the same patents as those they practice. In other instances, they use patents that they are not practicing in order to obtain cross-licenses from or deter patent assertions by other practicing entities, or to impose costs on competing practicing entities, and thereby to aid their businesses that practice other patents. And in yet other instances, they assert or sell patents they are not practicing simply in order to obtain revenue from them. In these instances, they are acting like trolls.

\section{ARe Trolls Really the Problem?}

Broadly speaking, the complaints about patent trolls fall into two categories. The most common is that patent assertions by trolls cannot be resolved or deterred by the prospect of counterassertions or business dealings because, by definition, the only business of trolls is to monetize their patents and that, for this reason, patent assertions by trolls are more costly than those by practicing entities. This complaint is addressed in Part II.A. The second is that, for reasons that are not inherent in the nature of trolls but which seem related to their business models, trolls engage more frequently than practicing entities in conduct that increases the costs of technology users while providing little if any countervailing benefit. This conduct is said to include asserting patents that would otherwise be ignored; aggregating large numbers of patents; imposing greater litigation costs; and engaging in abusive tactics. This complaint is addressed in Part II.B.

\section{A. Payments, Cross-Licenses, and Opportunity Costs}

It is inherent in the nature of trolls that they want a cash payout. They have no other businesses and are interested only in monetizing their patents. ${ }^{57}$ By contrast, patent assertions by practicing entities often settle with cross-licenses of their patent portfolios or with mutual deterrence reflecting the mutual vulnerability of the practicing entities to one another's patents. ${ }^{58}$ In the former instance, the technology user

56. See infra notes 129-130 and accompanying text (noting differing reasons practicing entities obtain patents).

57. One can imagine circumstances in which a troll would permit a technology user to pay by assigning its patents to the troll rather than by cash, but that is likely to be rare and would not, as should become clear below, make patent assertions by trolls less costly to the technology user. See infra Part II.A.1.a (discussing cost of bartering patents instead of paying cash).

58. See, e.g., Parchomovsky \& Wagner, supra note 49, at 26-27 (discussing and critiquing defensive theory of patenting, which suggests patents can serve as insurance against litigation). 
licenses its patents to the practicing entity that asserted patents against it in exchange for a license to the practicing entity's patents; in the latter instance, the parties simply forbear from asserting their patents against each other because each recognizes that it is vulnerable to the other's patents. Practicing entities frequently complain that they cannot use their own patents to deter or resolve patent assertions by trolls, evidently in the belief that trolls' insistence on cash makes patent holdings and assertions by trolls, all other things equal, more costly than patent assertions by practicing entities. ${ }^{59}$

1. Opportunity Costs. - The difference between cash payouts and cross-licenses is largely illusory. The complaint is that a technology user cannot barter its own patents to deter or offset patent assertions by trolls. But barter is not costless.

a. There Is No Free Lunch. - In the first place, acquiring and maintaining patents to use in barter is costly, ${ }^{60}$ and it can be especially costly if the patents are purchased from others. Indeed, smartphone companies alone spent over $\$ 15$ billion acquiring patents in the last three years to deter or offset assertions by other practicing entities. ${ }^{61}$ Concluding that

59. See, e.g., Letter from Google Inc., BlackBerry, EarthLink, Inc. \& Red Hat, Inc. to FTC \& U.S. Dep't of Justice 11-13 (Apr. 5, 2013) [hereinafter Letter from Google et al.], available at http://www.ftc.gov/os/comments/pae/pae-0047.pdf (on file with the Columbia Law Review) (discussing harms arising from inability to deter trolls, including reduced innovation and competition). For discussion and criticism of this argument, see Ted Sichelman, The Vonage Trilogy: A Case Study in "Patent Bullying," in Perspectives on Patentable Subject Matter (Michael Abramowicz et al. eds., forthcoming 2013) [hereinafter Sichelman, Vonage Trilogy], available at http://papers.ssrn.com/abstract= 1856703 (on file with the Columbia Law Review), which argues that the focus on trolls misses abuse of the patent system by other entities.

60 . Obtaining a patent costs roughly $\$ 20,000$, and maintaining it to the end of term costs roughly another $\$ 5,000$, depending on the size of the patent holder. Mark A. Lemley, Rational Ignorance at the Patent Office, 95 Nw. U. L. Rev. 1495, 1498-99 (2001) [hereinafter Lemley, Rational Ignorance]. Thus, with roughly 250,000 patents issuing every year as of 2012, see Patent Tech. Monitoring Team, U.S. PTO, U.S. Patent Statistics Chart: Calendar Years 1963-2012, http://www.uspto.gov/web/offices/ac/ ido/oeip/taf/us_stat.htm (on file with the Columbia Law Review) (last modified June 7, 2013, 10:59 PM), patent owners spend approximately $\$ 6.25$ billion obtaining and maintaining patents every year.

61. Google bought Motorola Mobility for $\$ 12.5$ billion. Press Release, Google, Google to Acquire Motorola Mobility: Combination Will Supercharge Android, Enhance Competition, and Offer Wonderful User Experiences (Aug. 15, 2011), http://investor. google.com/releases/2011/0815.html (on file with the Columbia Law Review). A consortium of technology companies purchased Nortel's patent portfolio for $\$ 4.5$ billion. Press Release, BlackBerry, RIM Participates in Winning Bid for Nortel's Patent Portfolio (July 1, 2011), http://press.blackberry.com/press/2011/pressrelease-5098.html (on file with the Columbia Law Review). Microsoft bought some patents from AOL, and an exclusive license for other patents, in a deal worth over $\$ 1$ billion. Press Release, AOL, AOL and Microsoft Announce \$1.056 Billion Patent Deal (Apr. 9, 2012), http://corp.aol.com/ 2012/04/09/aol-and-microsoft-announce-1-056-billion-patent-deal/ (on file with the Columbia Law Review). These transactions alone total $\$ 18$ billion, and do not include a number of smaller transactions. 
patents held by practicing entities do not impose costs on other practicing entities, just because they have paid little or no cash royalties or damages to one another, is like saying that nuclear weapons used to deter attacks are costless if they succeed in deterring attacks. They may be worth the money, but they are not free.

To be sure, the cost to the patent holder of acquiring and maintaining a patent portfolio might be less than the benefits it receives from using the patents to deter patent assertions by practicing entities or to reduce the cash payments required by those assertions. In fact, a patent holder that acquired and maintained a patent portfolio for other purposes might incur no additional patent acquisition and maintenance costs when it uses the patents to deter or resolve a subsequent patent assertion by a practicing entity. That does not mean, however, that using the patents to deter or resolve patent assertions by practicing entities is costless or inexpensive. To the contrary, when patents are used that way, they impose an opportunity cost on the patent holder.

An agreement not to collect money that could be obtained by asserting one's own patents is a cost, just like a cash payment. A crosslicense among industry participants in which each agrees to license its patents to the other puts an implicit value on the patents owned by each side. That value might not be fully understood, or it might be underestimated, but it is real nevertheless. If company $A$ and company $B$ each own 1,000 patents, and they agree to cross-license those patents rather than sue each other, each is giving up something valuable-the royalties they could collect by asserting the patents against the other party-in order to get a benefit they judge to be of comparable value-insulation from suit. In substance, although the companies are using barter instead of cash to pay for the right to use technologies claimed by each other's patents, the cost is equivalent. The same can be said when patents are used to deter patent assertions without a cross-license, whether by tacit agreement or by actual or implied threat.

The point can be illustrated by a simple numerical example. Suppose company $A$ holds patents that, if asserted against company $B$, would result in a cash judgment or settlement worth an expected $\$ 100$ million. If $B$ had no patents or if $A$ were a troll, $B$ would have to pay $\$ 100$ million to $A$ for a license to $A$ 's patents. But if $A$ was a practicing entity and $B$ held patents capable of imposing a comparable cash cost on $A, B$ could use those patents to deter the assertion by $A$ or to resolve it with a cross-license. If $B$ 's patents were capable of imposing only a much smaller cash cost on $A$-say, $\$ 10$ million-they would probably not be sufficient to deter assertions by $A$, but they could be used to offset the cash owed by $B$ to $A$ or to induce a cross-license between the two; in either case, $B$ would wind up paying $\$ 90$ million to $A .^{62}$

62. In the real world, of course, the story is more complicated. For one thing, a patent holder is often reluctant to license upstream manufacturers because doing so will 
In all of these cases, the cost to $B$ of the actual or avoided assertion by $A$ is $\$ 100$ million. In one case, the cost is $\$ 100$ million in cash; in another, it is $\$ 100$ million in revenues from patent assertion foregone; and in the third case, it is a combination of cash and foregone revenues totaling $\$ 100$ million. ${ }^{63}$

The issue is somewhat more complicated and less certain if something other than money and patents is at stake. Practicing entities that assert patents might have or anticipate having a business relationship with the alleged infringer and might thus act more cautiously in asserting patents for fear of damaging an actual or potential business relationship. In other words, the practicing entity patent holder might be maximizing a portfolio of assets that includes more than just patents. But the analysis in this case is the same, even though the exchange of value among the parties includes something other than cash and patent rights.

If the infringer and the practicing entity patent holder are actual or potential trading partners, the infringer can (assuming there are no contractual restrictions) terminate, threaten to terminate, or not initiate trading. If the costs of not trading are equally shared-that is, if not trading is as costly to the infringer as to the patent holder-or if the costs to the infringer are greater than the costs to the patent holder, either the infringer will be shooting itself in the foot or its threat will not be credible. But if the costs of not trading are less for the infringer, for example, the patent asserter is an essentially fungible competitor and the infringer is not fully replaceable as a trading partner, the infringer might be able to deter the practicing entity patent holder at little apparent cost by threatening not to do business with the practicing entity if it asserts its patents. This was the government's theory against Intel in the 1990s: that

generally exhaust the patent holder's rights to assert its patents against the licensed products, see generally Quanta Computer, Inc. v. LG Elecs., Inc., 553 U.S. 617 (2008) (discussing rules of patent exhaustion when patentees seek to recover from both upstream and downstream companies), and thus prevent the patent holder from asserting the patent against the manufacturer's customers and other downstream entities from which it might be able to collect greater sums. See infra Part II.B.4 (explaining how asserting against customers often enables collection of larger sums). But this exhaustion problem applies equally to trolls and practicing entities. Its effect on the analysis in the text, if any, is to reduce the deterrent and offset value of patents and thus the apparent difference between trolls and practicing entities. The reason is that the plaintiff-company $A$ in the story in the text—can choose the level in the distribution chain against which to assert its patents, but company $B$ might be reluctant to use its patents in response if it would be more profitable for $B$ to assert its patents against companies lower in the distribution chain than against $A$.

63. Cash and barter were found to be equivalent by the district court in Microsoft Corp. v. Motorola, Inc., No. C10-1823JLR, 2013 WL 2111217, at *65 (W.D. Wash. Apr. 25, 2013) ("Motorola contends that it is entitled to a royalty rate of $2.25 \%$ of the net selling price.... Motorola... is indifferent as to whether the value is in the form of monetary payment, a grant-back license, or another form of compensation."). 
Intel exercised its monopoly power in the chip market by refusing to do business with any entity that sued it for patent infringement. ${ }^{64}$

Even for a monopolist, however, refusing to do business with a partner because it asserts its patents has costs. The business relationship will enable the monopolist to deter the patent assertion only if the business relationship creates value for the patent holder that the monopolist is not otherwise extracting. In the usual case, the monopolist can either extract all of the value from the business relationship or use some of the value in barter to buy patent peace. It cannot, however, use the same trading value to do both. ${ }^{65}$ In that case, using the business relationship to keep patent peace is not costless because it entails a sacrifice of profits that would otherwise be realized from that relationship. ${ }^{66}$ The sacrifice of profits from the business relationship, like foregoing revenues that could be obtained by asserting patents, is an opportunity cost incurred to deter or offset the patent assertion. ${ }^{67}$

A cash payment to a troll might have a greater adverse impact on economic welfare than an opportunity cost of equal dollar value incurred to obtain a cross-license with or deter a patent assertion by a practicing entity if the cash payment takes the form of a per-unit royalty on each

64. Press Release, FTC, FTC Accepts Settlement of Charges Against Intel (Mar. 17, 1999), http://www.ftc.gov/opa/1999/03/intelcom.shtm (on file with the Columbia Law Review); cf. Intergraph Corp. v. Intel Corp., 195 F.3d 1346, 1350-51 (Fed. Cir. 1999) (discussing similar assertions by private company).

65. If the value to the patent holder of trading with the infringer is equal to or greater than the amount the patent holder could obtain by asserting its patents- $\$ 100$ million in the example above-the patent assertion can be deterred or a license obtained at no cash cost to the monopolist. But if that value is materially less than $\$ 100$ million, it will reduce but not eliminate entirely the amount the monopolist will have to pay if it is infringing the patents.

66. Barter might not entail an opportunity cost to the extent that the practicing entity is otherwise unable to extract from its trading partner the full value of the trade. That might be the case if and to the extent the practicing entity is unable to engage in price discrimination and must thus charge inframarginal trading partners less than they are willing to pay. The kinds of transactions used in barter, however, are likely to be individually negotiated and thus susceptible to price discrimination (in part because there is no standard exchange rate for bartering patents, much less for trading patents and business favors), although perhaps not to an extent sufficient to enable the technology user to extract all of the value from the business relationship.

67. In its case against Intel, the government argued, among other things, that Intel's refusal to do business with firms that asserted patents against it reduced the value of those firms' patents and thus reduced their incentives to innovate. Intel Corp.; Analysis to Aid Public Comment and Commissioner Statements, 64 Fed. Reg. 20,134, 20,135 (Apr. 23, 1999). The case was criticized by some at the time for not having identified a relevant market in which Intel's conduct injured or threatened to injure competition. E.g., id. at $20,138 \&$ n.3 (publishing statement of FTC Commissioner Orson Swindle). The analysis here suggests a more fundamental problem with the government's argument. Intel's conduct did reward its trading partners for their patents and thus their innovations, but it did so by barter rather than cash. 
product unit manufactured or sold by the technology user ${ }^{68}$ A running or per-unit royalty would increase the cost of producing and selling products subject to the royalty and would thus tend to increase prices charged to buyers, reduce product sales, and result in deadweight loss. ${ }^{69}$ By contrast, lump-sum payments, whether in cash or barter, are fixed expenses that generally do not affect marginal cost. ${ }^{70}$

It is not clear that this theoretical concern is of great practical significance. Although we know of no reliable data on the issue, it appears that trolls rarely resolve patent assertions with running royalties. ${ }^{71}$ Because their interest is in generating cash and their business models often depend critically on cash flow from patent assertions, they have no incentive to prefer running royalties and, if anything, are likely to prefer lump-sum payments. ${ }^{72}$ By contrast, as explained below, practicing entities are far more likely to insist on running royalties because they might have a strategic interest in raising the marginal cost of their competitors' products. $^{73}$ If anything, then, practicing entity royalties seem more likely to affect marginal cost and therefore to raise prices.

b. The Money Illusion. - Why, then, is it so common to think of crosslicenses and other noncash arrangements as costless and troll suits as costly? One answer is short-term thinking. Troll suits involve money that comes out of the quarterly budget; cross-licenses reflect longer-term opportunity costs rather than up-front cash payments. Those opportunity costs are not easy to measure or budget for, and so it is all too easy to ignore them. And there might be an agency problem if managers are

68. See Fiona M. Scott Morton, Deputy Assistant Att'y Gen. for Econ. Analysis, Antitrust Div., U.S. Dep't of Justice, Patent Portfolio Acquisitions: An Economic Analysis 3-4 (Sept. 21, 2012), available at http://www.justice.gov/atr/public/speeches/288072.pdf (on file with the Columbia Law Review) (detailing adverse effects of troll royalty stacking on market).

69. See id. at 8 (discussing negative effects high royalties have on producers and consumers).

70. In some situations, a party might anticipate having to make a future lump-sum payment on account of the manufacture, sale, or use of a particular product and might thus impute the cost of the payment to the activity that is likely to give rise to it. In that event, the prospect of the lump-sum payment would tend to have the same kinds of adverse welfare effects as a running royalty.

71. Trolls do, however, obtain running royalties on occasion. See, e.g., Soverain Software LLC v. J.C. Penney Corp., 899 F. Supp. 2d 574, 588-90 (E.D. Tex. 2012). The plaintiff in that case is a troll. Joe Mullin, How Newegg Crushed the "Shopping Cart" Patent and Saved Online Retail, Ars Technica (Jan. 27, 2013, 4:00 PM), http:// arstechnica.com/tech-policy/2013/01/how-newegg-crushed-the-shopping-cart-patent-andsaved-online-retail/ (on file with the Columbia Law Review) ("Court records show Soverain hasn't made a sale-ever.").

72. Trolls might prefer lump-sum payments for other reasons as well. Running royalties would impose administrative burdens and might complicate the trolls' dealings with their financial investors. Also, a running royalty is more likely to provide a benchmark for royalties in subsequent assertions; because more is thus at stake with running royalties, trolls can resolve assertions more quickly and with less risk by lump-sum payments.

73. See infra notes 123-126 and accompanying text. 
more concerned about costs that show up in the quarterly budget than about long-term opportunity costs of equivalent economic magnitude for which they might not be held responsible. ${ }^{74}$ Agency and cognitive issues might contribute to the illusion in another way as well. It is probably a lot easier for management to say it lost a patent case as an asserter, i.e., for the company not to collect money today while it tries to get maximum value from its portfolio, than to say it lost a great deal of money as an alleged infringer. The latter is a more glaring failure. Indeed, as Amos Tversky and Daniel Kahneman have famously demonstrated, people systematically give more weight to a loss (for example, paying royalties to a patent holder) than to a gain (for example, collecting an equal amount of royalties from others). ${ }^{75}$ To an economist, losing $\$ 100$ million as a defendant in a patent dispute and not winning $\$ 100$ million as a plaintiff are roughly equivalent. But to a businessperson, they most definitely are not.

A second answer might be that many companies, particularly in the IT industry, do not see patents as a monetizable asset. They do not sue other companies, and they do not threaten to sue in order to generate licensing revenue. They obtain patents both to prevent copying of their key products and product features and to play the cross-licensing game with other practicing entities that hold patents. ${ }^{76}$ For a company that thinks of its patents only as chips that can be traded in cross-licenses, the patents have value only in dealings with practicing entities for which a cross-license is a feasible solution, either in lieu of or in settlement of litigation with other practicing entities. These companies do not perceive an opportunity cost from not using their patents more broadly.

These companies are undervaluing their patent portfolios, and they are probably being short-sighted as well. Indeed, many companies that profess to obtain patents only for defensive purposes when they are young and growing turn out to be willing to assert those patents against competitors when circumstances change. ${ }^{77}$ Microsoft in the 1990s disliked software patents; it started acquiring them after it got sued by a competitor, Stac, and lost a substantial verdict. ${ }^{78}$ At the time, Microsoft

74. On the problems of agency costs, see generally Frank H. Easterbrook \& Daniel R. Fischel, Close Corporations and Agency Costs, 38 Stan. L. Rev. 271 (1986) (discussing conflicts of interest as agency costs in closely held corporations).

75. Amos Tversky \& Daniel Kahneman, Loss Aversion in Riskless Choice: A Reference-Dependent Model, 106 Q.J. Econ. 1039, 1040 (1991).

76. See Stuart J.H. Graham et al., High Technology Entrepreneurs and the Patent System: Results of the 2008 Berkeley Patent Survey, 24 Berkeley Tech. L.J. 1255, 12961309 (2009) (discussing reasons technology startups acquire patents).

77. Indeed, Wilson defines asserting patents for revenue as one of the four phases of patent usage. Kelce Wilson, The Four Phases of Patent Usage, 40 Cap. U. L. Rev. 679, 689 (2012).

78. Cf. Rick Nydegger, B2B, B2C and Other "Business Methods": To Be or Not to Be Patent Eligible?, 9 U. Balt. Intell. Prop. L.J. 199, 215 n.48 (2001) (noting but discounting theory that Stac suit prompted Microsoft to begin patenting). 
had no interest in suing anyone for patent infringement. But in recent years, it has increasingly turned to patent litigation to extract royalties from its competitors, particularly in the smartphone business. ${ }^{79}$ Similarly, Yahoo long viewed its patent portfolio as a defensive one, but as its fortunes in social media declined, it began suing younger companies like Facebook..$^{80}$ Other examples abound. Texas Instruments, for instance, evolved in the 1990s from being a very successful hardware company to a company with a small manufacturing business and a very lucrative patent portfolio. ${ }^{81}$ The same is true of Alcatel,,$^{82}$ MOSAID, ${ }^{83}$ and Tessera $;{ }^{84}$ Nokia seems to have embarked on a similar path. ${ }^{85}$ Companies that say they

79. Microsoft has sued a number of smartphone makers for patent infringement. See, e.g., Horacio Gutierrez, Microsoft Sues Motorola over Android Patent Infringements, Microsoft on the Issues (Oct. 1, 2010, 11:37 AM), http://blogs.technet.com/b/Microsoft_ on_the_issues/archive/2010/10/01/Microsoft-sues-motorola-over-android-patent-infringe ments.aspx (on file with the Columbia Law Review).

80. See Barbara Ortutay, Yahoo Sues Facebook over Patents, USA Today (Mar. 12, 2012, 7:33 PM), http://usatoday30.usatoday.com/tech/news/story/2012-03-12/yahoosuing-facebook/53501860/1 (on file with the Columbia Law Review) (discussing Yahoo's three-year decline in revenue and subsequent patent infringement suit against Facebook). The parties have since settled. Michael J. de la Merced, Yahoo and Facebook Settle Patent Lawsuits, N.Y. Times: Dealbook (July 6, 2012, 1:10 PM), http://dealbook.nytimes.com/ 2012/07/06/yahoo-and-facebook-said-to-settle-patent-lawsuits (on file with the Columbia Law Review).

81. See Susan Decker, Kodak in Crisis Mines Patents for Cash Copying Texas Instruments, Bloomberg (Jan. 13, 2012, 12:00 AM), http://www.bloomberg.com/news/ 2012-01-13/kodak-mines-patents-for-cash-copying-texas-instruments.html (on file with the Columbia Law Review) ("Texas Instruments... wrote the template decades ago on techniques to exploit patent holdings when a company is struggling ....").

82. See, e.g., Joe Mullin, Newegg Nukes "Corporate Troll" Alcatel in Third Patent Appeal Win This Year, Ars Technica (May 16, 2013, 9:15 AM), http://arstechnica.com/ tech-policy/2013/05/newegg-nukes-corporate-troll-alcatel-in-third-patent-appeal-win-thisyear/ (on file with the Columbia Law Review) (describing Alcatel as "corporate troll").

83. See About, Conversant Intellectual Prop. Mgmt., http://conversantip.com/ about/ (on file with the Columbia Law Review) (last visited Oct 13, 2013) (noting MOSAID—now named Conversant-is "company of patent licensing professionals and innovators offering IP management services").

84. The Tessera board of directors recently lost a proxy battle to a hedge fund accused of wanting to turn the company into a troll, see Peter Delevett, San Jose's Tessera Technologies Loses Proxy Showdown with Hedge Fund, Agrees to Sweeping Management Changes, San Jose Mercury News (May 24, 2013, 4:46 PM), http://www.mercurynews.com/ ci_23319092/san-joses-tessera-technologies-loses-proxy-showdown-hedge (on file with the Columbia Law Review), over the dissent of Tessera's CEO, see Richard S. Hill, Don't Turn My Company into a Patent Troll!, Forbes (May 13, 2013, 11:40 AM), http:// www.forbes.com/sites/forbesleadershipforum/2013/05/13/dont-turn-my-company-into-apatent-troll/ (on file with the Columbia Law Review) (describing plea of chairman and interim CEO of Tessera for stockholders to vote against plan to "eviscerate Tessera's R\&D and rely instead on hyper-aggressive patent troll-style litigation to build revenues").

85. After the recent sale of Nokia's mobile device and services business to Microsoft, Nokia plans to focus on expanding its remaining patent licensing operation, which covers a portfolio of over 10,000 patent families. Ian Delaney, Nokia Reinvented: Our Chairman \& Interim CEO, Risto Siilasmaa, Explains Nokia's Future, Nokia Conversations (Sept. 11, 
want patents for defensive purposes often end up using them offensively later. Giving up that possibility via cross-license or mutual deterrence is a form of opportunity cost.

Even if a firm does not want to assert its patents, there is often an opportunity cost from not selling those patents to another firm that will assert them. Companies that are willing to use patents only in crosslicenses, but not to generate revenue, are often leaving money on the table. One way to pick up some of that money without filing lawsuits is to sell some of their patents to other firms that are willing to use them to generate revenue. This has not gone unnoticed, and practicing entities have increasingly monetized portions of their patent portfolios by selling patents to others, a practice we discuss below. ${ }^{86}$ Among other things, selling patents enables firms to realize value from their patents without having to sue the infringers and thereby jeopardize profitable business relationships with them. ${ }^{87}$

Usually, firms sell patents to the highest bidder. Notably, however, the amount a buyer will pay for a patent depends in part on the extent to which the patent is licensed to others. The more widely it is licensed, the less is its value to others. In this way, too, using a patent for cross-licenses to deter or resolve patent assertions imposes a cost on the patent holder.

Sometimes, firms sell patents in more strategic ways. One example is the recent rise of patent privateers-product-producing companies that spin off patents or ally with trolls to target other firms with lawsuits. ${ }^{88}$ For example, Nokia has spun off patents to MOSAID, another former practicing entity turned troll. ${ }^{89}$ Micron spun off many of its patents to Round Rock Ventures, a troll that asserted those patents against Micron's competitors. ${ }^{90}$ Ericsson spun off more than 2,000 patents to Unwired

2013), http://conversations.nokia.com/2013/09/11/nokia-reinvented/ (on file with the Columbia Law Review).

86. See infra notes 179-180 and accompanying text (explaining strategic practice of allocating rights to different entities).

87. See supra Part II.A.1.a (discussing impact of business relationship on patent assertion behavior by practicing entities).

88. See, e.g., Tom Ewing, Indirect Exploitation of Intellectual Property Rights by Corporations and Investors, Hastings Sci. \& Tech. L.J., Winter 2012, at 1, 5 (defining intellectual property (IP) privateering).

89. Press Release, MOSAID, MOSAID Acquires 1,200 Nokia Standards-Essential Wireless Patents and 800 Wireless Implementation Patents (Sept. 1, 2011) (on file with the Columbia Law Review); see also Derrick Harris, Are Microsoft and Nokia Closet Patent Trolls? Let the EC Decide., GigaOM (May 31, 2012, 4:36 PM), http://gigaom.com/2012/ $05 / 31 /$ are-microsoft-and-nokia-closet-patent-trolls-let-the-ec-decide/ (on file with the Columbia Law Review).

90. Patrick Anderson, Micron Retains Interest in Round Rock Patent Monetization Proceeds, Gametime IP (May 9, 2012), http://gametimeip.com/2012/05/09/micronretains-interest-in-round-rock-patent-monetization-proceeds/ (on file with the Columbia Law Review). 
Planet, a patent troll suing Ericsson's competitors. ${ }^{91}$ British Telecom spun patents off to IPValue while retaining an interest in the revenue it raised from privateering. ${ }^{92}$ Broadcom spun patents off to Innovatio, which is using them to sue small businesses that use wireless internet. ${ }^{93}$ And Microsoft, Apple, and others formed a joint venture, called "Rockstar Bidco," both to acquire patent rights in smartphone technology and to establish a new entity that could assert those patents against others. ${ }^{94}$ Indeed, Michael Risch finds that most troll-owned patents come not from bankrupt firms, but from practicing entities spinning out parts of their portfolios. ${ }^{95}$

If the privateer does not control the entity to which it transfers its patents, it cannot directly control how the entity uses the patents. The privateer can, however, significantly influence how the patents are used. It can do so by contract or by transferring patents that, because they are already widely licensed or cover technologies that are not widely used, can as a practical matter be asserted against only a small number of technology users. ${ }^{96}$

Unless companies are planning to liquidate, they usually sell only patents that are more valuable to others-perhaps because the others do

91. Dan Graziano, Ericsson Sold More than 2,000 Patents to a Patent Troll Suing Apple, Google and RIM, BGR (Jan. 11, 2013, 8:31 PM), http://bgr.com/2013/01/11/ ericsson-patent-sale-unwired-planet-289522/ (on file with the Columbia Law Review).

92. See Suffolk Techs. LLC v. AOL Inc., 910 F. Supp. 2d 850, 853-54 (E.D. Va. 2012) (disclosing structure of British Telecom-IPValue deal).

93. Matt Rizzolo, Catching Up on ... Innovatio IP Ventures, LLC's Litigation Activities, Essential Patent Blog (Jan. 3, 2013), http://essentialpatentblog.com/2013/01/ catching-up-on-innovation-ip-ventures-llcs-litigation-activities/ (on file with the Columbia Law Review).

94. Robert McMillan, How Apple and Microsoft Armed 4,000 Patent Warheads, Wired (May 21, 2012, 6:30 AM), http://www.wired.com/wiredenterprise/2012/05/ rockstar/ (on file with the Columbia Law Review).

95. Michael Risch, Patent Troll Myths, 42 Seton Hall L. Rev. 457, 461 (2012) [hereinafter Risch, Myths]. Businesses might be reluctant to sell their patents to trolls for moral or public relations reasons, just as they are reluctant to file suit themselves. Some companies, like Twitter, have committed both not to assert patents from employees' inventions without first obtaining the permission of the inventors and to ensure that the employee-inventors will be able to control how future purchasers use the patents on their inventions. Adam Messinger, Introducing the Innovator's Patent Agreement, Twitter Blogs (Apr. 17, 2012, 5:00 PM), https://blog.twitter.com/2012/introducing-innovators-patentagreement (on file with the Columbia Law Review). These companies are paying an opportunity cost by limiting the value of their patent portfolios; they are willing to pay that cost because they see the public relations benefits of their commitment as outweighing the cost of limiting portfolio value. But these companies are the exception, not the rule.

96. See, e.g., Ewing \& Feldman, supra note 12, at 13 (describing Intellectual Ventures's tactic of selling patent to aggressive licensing company while retaining license for its investors, so new owner may sue anyone not covered by Intellectual Ventures). For a critical discussion of contractual provisions practicing entities could use to channel the enforcement efforts of the entities to which they transferred patents, see Letter from Google et al., supra note 59, at 17-18. 
not have the same commercial or other obstacles to asserting them-or that are redundant because the patent holder has many other patents that can be asserted against the same products or revenue streams. And in our experience, companies rarely sell their "crown jewels"-patents that they need to prevent copying of technologies they consider critical to their own business-even with a license back to practice the patented technologies. Still, to the extent that a company is unwilling to sell its patents, it incurs an opportunity cost by sacrificing the consideration it could get from selling them.

In short, when technology users use patents or business relationships to deter or offset patent claims, they incur opportunity costs. And when opportunity costs, and not just cash costs, are taken into account, it is apparent that the complaint that patent assertions by trolls are more costly because they cannot be deterred or offset generally has little economic substance.

2. Why Assertions by Practicing Entities Can Be More Costly. - While patent assertions by trolls are often said to be more costly than assertions by practicing entities, ${ }^{97}$ there are actually a number of factors that have precisely the opposite effect, holding constant the likelihood that the asserted patents are valid and infringed. All of these factors reflect aspects of the patent laws that create litigation opportunities for practicing entities that are generally not available to trolls. Those opportunities affect judicial decisions and settlements as well as licenses and other extrajudicial agreements between patent holders and technology users that are negotiated in the shadow of litigation.

First, patent damages are generally determined by juries. ${ }^{98}$ An inventor, whether an individual or a company, can often tell a sympathetic story of how it toiled to make the invention and how much it thereby contributed to the world. Even a practicing entity that is not the inventor might have an attractive story if it is using the patented technology to make products or provide services. A troll has a harder time telling such a story, particularly if it bought the patent from someone else. And indeed the largest jury verdicts tend to be awarded to practicing entities, not trolls. ${ }^{99}$

97. See supra note 55 and accompanying text (discussing critique of troll costs imposed through assertion of weak patents); supra note 59 and accompanying text (discussing criticism of patent trolls as more costly because of trolls' insistence on cash payment).

98. See Mark A. Lemley et al., Rush to Judgment? Trial Length and Outcomes in Patent Cases, 41 AIPLA Q.J. 169, 173 tbl.1 (2013) (finding roughly 75\% of patent cases are tried before juries).

99. Of patent verdicts awarding over $\$ 1$ billion, one was to a truly nonpracticing entity, and that verdict was in favor of Carnegie Mellon University, which is neither a practicing entity nor a troll by most definitions. Margaret Cronin Fisk, Patent Trial Awards Soar with Some Big Ones Cut by Judges, Bloomberg (Jan. 18, 2013, 12:00 AM), http:// www.bloomberg.com/news/2013-01-18/patent-trial-awards-soar-with-some-big-ones-cut-by- 
Second, patent damages—at least as classically understood—should be higher when practicing entities assert patents than when trolls do. ${ }^{100}$ Only practicing entities are entitled to lost profits, and in theory lost profits should generally exceed the statutory floor of reasonable royalties. ${ }^{101}$

Third, injunctions are more likely to be granted to practicing entities than to trolls. An injunction, or the threat thereof, enables the patent holder to bargain for payments up to the cost of replacing the allegedly infringing technology in an existing product or, if that is not feasible, up to the rents available to the infringer from the enjoined product. The cost of replacing a technology in an existing product often requires redesigning the product or facilities used to manufacture it and changing complementary components and products; this cost is usually greater than the cost of choosing a different technology when the product is first being planned. ${ }^{102}$ The cost of switching technologies is thus often greater than the value of the patented technology itself. In

judges.html (on file with the Columbia Law Review). A second verdict was in favor of Alcatel-Lucent, see Ina Fried, Microsoft Hit with \$1.5 Billion Patent Verdict, CNET News (Feb. 22, 2007, 2:48 PM), http://news.cnet.com/Microsoft-hit-with-1.5-billion-patentverdict/2100-1030_3-6161480.html (on file with the Columbia Law Review), a practicing entity but one whose business is increasingly patent assertion. See supra note 82 (calling Alcatel patent troll). Other large verdicts have gone to practicing entities-Centocor Ortho Biotech, Monsanto, and Apple-in suits against actual or potential competitors. See Apple-Samsung Verdict Third Largest Ever in U.S. Patent Litigation: Lex Machina Data Confirms Historic Nature of Verdict, Lex Machina (Aug. 24, 2012), https://lexmachina. com/2012/08/24/apple-samsung-verdict-third-largest-ever-in-u-s-patent-litigation/ (on file with the Columbia Law Review) (describing largest verdicts in patent litigation); see also Fisk, supra (highlighting awards to Monsanto and Apple).

100. As a general matter, patentees are entitled to recover their lost profits if they are practicing entities, and in no event less than a reasonable royalty for the defendant's use if they are trolls. 35 U.S.C. $\$ 284$ (2006). The statute contemplates that the reasonable royalty measure will be a floor on the amount of damages that the patent holder may elect to recover if it is unable to prove lost profits. For a discussion distinguishing lost profits from reasonable royalties and noting the division among court interpretations, see Mark A. Lemley, Distinguishing Lost Profits from Reasonable Royalties, 51 Wm. \& Mary L. Rev. 655 (2009) [hereinafter Lemley, Distinguishing Lost Profits].

101. There is, however, some evidence that this is not true in practice. Because courts have failed to effectively apportion reasonable royalty damages, see Mark A. Lemley \& Carl Shapiro, Patent Holdup and Royalty Stacking, 85 Tex. L. Rev. 1991, 2021-24 (2007) [hereinafter Lemley \& Shapiro, Patent Holdup] (finding courts award excessive royalties in component cases), plaintiffs sometimes prefer reasonable royalties to their actual lost profits. Lemley, Distinguishing Lost Profits, supra note 100, at 667; Brian J. Love, The Misuse of Reasonable Royalty Damages as a Patent Infringement Deterrent, 74 Mo. L. Rev. 909, 922-23 (2009) [hereinafter Love, Misuse]; cf. Brian J. Love, Note, Patentee Overcompensation and the Entire Market Value Rule, 60 Stan. L. Rev. 263, 278-83 (2007) [hereinafter Love, Patentee Overcompensation] (discussing additional adverse consequences of overcompensating patentees). One study found that patent troll, or nonpracticing entity, damages actually exceed practicing entity damages on average. $\mathrm{PwC}$, supra note 14 , at 5,7 .

102. Lemley \& Shapiro, Patent Holdup, supra note 101, at 1995-2010. 
addition, in industries such as the IT industry, in which products commonly use literally thousands of patented technologies and other components, the value of the finished product is typically far greater than the value of the individual patented technologies asserted in any one suit. Furthermore, the threat of an injunction can deter a defendant's customers, who fear they will lose a reliable source of supply depending on the uncertain outcome of the patent suit, and in that way, too, can increase the alleged infringer's costs. For all of these reasons, the prospect of an injunction often leads to settlements in which the alleged infringer pays far more than the value of the patented technology and more than a court would award in damages. ${ }^{103}$

It used to be the case that courts routinely awarded injunctions to all successful plaintiffs in patent infringement cases. ${ }^{104}$ But in 2006, the Supreme Court ruled in eBay Inc. v. MercExchange, L.L.C. that injunctions should not issue as a matter of course in patent infringement cases. ${ }^{105}$ The Court held that courts should use the same equitable criteria when deciding whether to issue an injunction in a patent infringement case as those used in other cases. ${ }^{106}$ Those criteria require courts to consider whether the party seeking the injunction would suffer irreparable injury absent an injunction, whether money damages would be an adequate remedy, the balance of hardships between the parties, and the public interest. ${ }^{107}$

The $e$ Bay decision raised the bar for the issuance of injunctions in infringement suits brought by both trolls and practicing entities, but the bar for practicing entities is much lower than that for trolls. ${ }^{108}$ Practicing

103. Id. at 2008.

104. Dan L. Burk \& Mark A. Lemley, The Patent Crisis and How the Courts Can Solve It 137-38 (2009) [hereinafter Burk \& Lemley, Patent Crisis] (“[T]he assumption that a finding of patent infringement would be accompanied by an injunction was almost universal from the mid-1980s until 2006.").

105. 547 U.S. 388, 394 (2006). Using damages remedies (liability rules) instead of injunctions (property rules) would seem to be appropriate as a general matter where, as is commonly the case in the IT industry, infringement is ubiquitous and inadvertent, and ex ante negotiations between patent holders and technology users are impractical. See infra notes 135-138 and accompanying text (highlighting how fast-moving pace of IT industry leads to simultaneous invention and inadvertent infringement). See generally Guido Calabresi \& A. Douglas Melamed, Property Rules, Liability Rules, and Inalienability: One View of the Cathedral, 85 Harv. L. Rev. 1089, 1106-10 (1972) (considering when to use property and liability rules).

106. eBay, 547 U.S. at 391 (noting principles of equity "apply with equal force to disputes arising under the Patent Act"). Critics argue that the eBay decision misstated and misapplied these traditional equitable factors. See Mark P. Gergen et al., The Supreme Court's Accidental Revolution? The Test for Permanent Injunctions, 112 Colum. L. Rev. 203, 207-14, 232-33 (2012) (criticizing eBay as "incomplete and mischaracterized along a number of dimensions").

107. eBay, 547 U.S. at 391.

108. See Chien \& Lemley, supra note 27, at 10 fig.1 (finding $79 \%$ of practicing entities, but only $26 \%$ of trolls, won injunctions after eBay). Practicing entities, however, 
entities are usually able to get injunctions ${ }^{109}$ and are often able to use the threat of injunctions to extract favorable settlements from alleged infringers. ${ }^{110}$ After $e$ Bay, trolls are rarely able to do so because they almost never satisfy the eBay criteria. ${ }^{111}$ Monetary damages are almost always adequate for firms whose business is asserting patents in order to generate cash, and trolls usually cannot point to irreparable harm to

are rarely able to get injunctions for infringement of patents that are essential to industry standards and that they have committed to license on fair, reasonable, and nondiscriminatory (FRAND, or sometimes RAND) terms, because their commitment to license the patents is understood to mean that monetary compensation is an adequate remedy for the infringement. See, e.g., Apple, Inc. v. Motorola, Inc., 869 F. Supp. 2d 901, 914-15 (N.D. Ill. 2012) ("By committing to license its patents on FRAND terms, Motorola committed to license the [patent] to anyone willing to pay a FRAND royalty and thus implicitly acknowledged that a royalty is adequate compensation for a license to use that patent."); see also Mark A. Lemley \& Carl Shapiro, A Simple Approach to Setting Reasonable Royalties for Standard-Essential Patents, 28 Berkeley Tech. L.J. (forthcoming 2013) (manuscript at 7) [hereinafter Lemley \& Shapiro, A Simple Approach] (on file with the Columbia Law Review) (noting patent holder "who has made a FRAND commitment has already declared that royalties are sufficient to compensate it for infringement by compliant products" and suggesting patent holder making FRAND commitment explicitly state it has given up right to seek injunction).

109. See Chien \& Lemley, supra note 27, at 10 fig.1 (noting approximately four-fifths of practicing entities are granted injunctions). A recent decision by the Federal Circuit, Apple Inc. v. Samsung Electronics Co., may change that, making injunctions unavailable as long as the defendant can readily design around the patent. 695 F.3d 1370, 1377 (Fed. Cir. 2012). But it is far from clear that that decision, which concerned a preliminary injunction, id. at 1373, will be applied to permanent injunctions, even though the standards are nominally the same.

110. Lemley \& Shapiro, Patent Holdup, supra note 101, at 2008-11 (discussing how threat of injunction enables patent holder to negotiate settlements worth more than expected damages).

111. Chien \& Lemley, supra note 27 , at 10-12 (documenting low grant rate of injunctions for trolls after eBay). The eBay decision does not apply to cases brought in the International Trade Commission seeking an exclusion order barring the importation of infringing goods, and the effects of an exclusion order are very similar to those of an injunction. The statute that governs such ITC proceedings requires that complainants represent a domestic industry that is harmed by the infringing imports. 19 U.S.C. $\S 1337$ (a) (1) (A) (2012) (declaring unlawful "unfair acts in the importation of articles ... into the United States, or in the sale of such articles by the owner, importer, or consignee, the threat or effect of which is ... to destroy or substantially injure an industry in the United States"). While some have argued that trolls cannot meet the domestic industry requirement, in past cases the ITC has found that a troll's domestic patent licensing program can be sufficient to meet the requirement. See, e.g., InterDigital Commc'ns, LLC v. Int'l Trade Comm'n, 707 F.3d 1295, 1303-04 (Fed. Cir. 2013) (holding party that has substantially invested in intellectual property may meet domestic industry requirement even if it does not manufacture product domestically). Thus, although the ITC and its administrative law judges have recently shown an interest in applying a more rigorous public interest analysis before issuing exclusion orders, which could be used to limit exclusion orders given to trolls, see Chien \& Lemley, supra note 27, at 27-28 (highlighting recent ITC decision to delay start of exclusion order involving smartphones), the threat of an exclusion order remains real in ITC proceedings whether the complainant is a troll or practicing entity. 
their product businesses or loss of jobs or other public harms from the continued sale of infringing products. ${ }^{112}$

Fourth, practicing entities often have strategic interests that lead them to seek not only injunctions, but also higher royalties or settlement payments than a troll would seek. The starting point to understanding this is the recognition that for both legal and practical reasons damages in patent infringement suits by both practicing entities and trolls are not only somewhat unpredictable but, as a general matter, excessive.

Patent damages are unpredictable because the criteria most commonly used are imprecise and difficult to apply. ${ }^{113}$ Patent damages tend to be overstated for two basic reasons. First, the economic value of a patent, and thus the economically appropriate royalty for use of the patented technology, is widely understood to be the difference between the value of the patented technology and the next best alternative, determined before technologies are chosen and users are more or less locked into them. ${ }^{114}$ Patent damages law does not rigorously reflect this approach to valuation. While some cases have moved in this direction, ${ }^{115}$ most cases assess damages by an unsystematic application of the so-called Georgia-Pacific factors. ${ }^{116}$ The cases as a whole are still a long way from

112. For arguments that remedies should not distinguish between practicing entities and trolls, see John M. Golden, Commentary, "Patent Trolls" and Patent Remedies, 85 Tex. L. Rev. 2111, 2148-61 (2007) ("[A] doption of a discriminatory system of remedies . . threatens not only to mock true 'equity' but also to discourage efficient markets in innovation and patent-rights ownership."); Ted Sichelman, Purging Patent Law of 'Private Law' Remedies, 92 Tex. L. Rev. (forthcoming 2014) (manuscript at 39), available at http://papers.ssrn.com/abstract=1932834 (on file with the Columbia Law Review) ("Neither non-practicing nor manufacturing entities should routinely be entitled to an injunction as a matter of equity ....").

113. The standard generally used for determining reasonable royalties is a nonexclusive, fifteen-factor test derived from Georgia-Pacific Corp. v. United States Plywood Corp., 318 F. Supp. 1116, 1120 (S.D.N.Y. 1970), modified on other grounds sub nom. Georgia-Pacific Corp. v. U.S. Plywood-Champion Papers, Inc., 446 F.2d 295 (2d Cir. 1971). Critics argue that this test is imprecise. See, e.g., Daralyn J. Durie \& Mark A. Lemley, A Structured Approach to Calculating Reasonable Royalties, 14 Lewis \& Clark L. Rev. 627, 629-33 (2010) (arguing test gives juries little practical guidance); Love, Misuse, supra note 101, at 913-14 (criticizing test as relying on "counterfactual assumptions designed to favor the patentee").

114. See, e.g., Durie \& Lemley, supra note 113, at 637-39 (discussing determination of incremental contribution of patented technology); Richard J. Gilbert, Deal or No Deal? Licensing Negotiations in Standard-Setting Organizations, 77 Antitrust L.J. 855, 862 (2011) (acknowledging alternative, unpatented technology in calculation of economic value of patent).

115. E.g., Uniloc USA, Inc. v. Microsoft Corp., 632 F.3d 1292, 1311-18 (Fed. Cir. 2011); Grain Processing Corp. v. Am. Maize-Products Co., 185 F.3d 1341 (Fed. Cir. 1999).

116. While Georgia-Pacific is only a district court decision, it has been cited forty-nine times by the Federal Circuit, based on an October 22, 2013, WestlawNext search. Search Results, WestlawNext, http://www.westlawnext.com (search "318 F. Supp. 1116"; go to "Citing References" tab; filter by "Federal Circuit") (on file with the Columbia Law Review) (last visited Oct. 22, 2013). 
aligning with economic theory; even recent cases have awarded damages on the basis of factors, such as the entire value of the defendant's product, which imply awards in excess of the economically appropriate measure. ${ }^{117}$

Second, especially in the IT industry, products commonly use technologies claimed by thousands of patents. In principle, patent damages could take account of the multiplicity of technologies in a product and allocate value among them accordingly, but that rarely happens. Practical or court-ordered limits on the length of trials usually prevent a full exploration of all the technologies and value contributors in a product. Moreover, even where litigants attempt to explain the full range of technologies to the factfinder, which is usually a jury, the intense focus in the trial on the patents-in-suit almost guarantees that their importance will be exaggerated relative to that of the other technologies and, thus, that the damages award will be based on an inflated sense of the value of the patents-in-suit. ${ }^{18}$ And of course, settlements and other transactions in the shadow of actual or threatened litigation will be influenced by the prospect of such inflated damages awards. ${ }^{19}$

At least metaphorically, we might think of a single patent asserter in the IT industry (practicing entity or troll) as a party with market power, i.e., the ability to command an excessive price for its assets. ${ }^{120}$ A party with market power does not, however, seek to charge the highest possible

117. See, e.g., Verdict Form at 6, Carnegie Mellon Univ. v. Marvell Tech. Grp., Ltd., No. 09-290 (W.D. Pa. Dec. 26, 2012), 2012 WL 6686094 (documenting jury award of \$1.2 billion on component patent).

118. Research by economists and psychologists has shown that judgments are heavily biased toward the factor or "anchor" on which the decisionmaker initially focused. See, e.g., Gretchen B. Chapman \& Eric J. Johnson, Incorporating the Irrelevant: Anchors in Judgments of Belief and Value, in Heuristics and Biases: The Psychology of Intuitive Judgment 120, 120-21 (Thomas Gilovich, Dale Griffin \& Daniel Kahneman eds., 2002). This effect applies in legal proceedings as well. See, e.g., Gretchen B. Chapman \& Brian H. Bornstein, The More You Ask for, the More You Get: Anchoring in Personal Injury Verdicts, 10 Applied Cognitive Psychol. 519, 533-38 (1996) (noting anchoring effects on causality judgments, compensation awards, and litigant perceptions in juror simulations); Birte Englich, Thomas Mussweiler \& Fritz Strack, The Last Word in Court-A Hidden Disadvantage for the Defense, 29 Law \& Hum. Behav. 705, 706-08 (2005) (discussing anchoring).

119. See Lemley \& Shapiro, Patent Holdup, supra note 101, at 2017-25 (exploring economics of this feedback mechanism).

120. There is extensive discussion regarding the circumstances under which IP rights confer market power. See, e.g., Ill. Tool Works Inc. v. Indep. Ink, Inc., 547 U.S. 28, 38-43 (2006) (rejecting presumption IP rights confer market power). See generally, e.g., Ariel Katz, Making Sense of Nonsense: Intellectual Property, Antitrust, and Market Power, 49 Ariz. L. Rev. 837, 852-71 (2007) (discussing various theories of IP rights and market power); Mark A. Lemley \& Mark P. McKenna, Is Pepsi Really a Substitute for Coke? Market Definition in Antitrust and IP, 100 Geo. L.J. 2055 (2012) (arguing market power for IP is spectrum rather than simply present or not present). We intend not to revisit that broad issue here, but rather to suggest that as a practical matter, patent remedy law gives some patents at least some power over price. 
price or, in this case, royalty. Instead, it charges the profit-maximizing price or royalty. Because the marginal cost of patent licensing is or can be deemed to be essentially zero, the profit-maximizing royalty is the revenue-maximizing royalty. ${ }^{121}$ If the patent holder intends to collect a running or per-unit royalty on future sales, the revenue-maximizing royalty is that which will lead to the highest product of per-unit royalty times the number of units during the term of the patent. The higher the per-unit royalty, the fewer units the licensee will sell; beyond a point, the per-unit royalty is so high that total revenues decline. A revenuemaximizing patent holder, whether a practicing entity or a troll, will not seek royalties above the level that will maximize its revenues. ${ }^{122}$

Some practicing entities, however, are willing to seek running royalties above that level. These practicing entities are acting not to maximize revenues from their patents, but to maximize profits from their product business. Their objective is to impose royalty costs on competitors that will reduce demand for the competitors' products and thereby increase demand for their own products. ${ }^{123}$ They will seek to do so as long as the additional profits from product sales they can generate exceed the competitors' royalty revenues that they sacrifice to pursue the scheme. ${ }^{124}$ In effect, these practicing entities are willing, for strategic reasons, to charge supramonopoly prices: prices that are higher than those a troll would charge. The imprecise and often excessive damages awards that patent law provides enable practicing entities to pursue such strategies. ${ }^{125}$

121. In the rare instance in which this is not the case, the difference will not affect the analysis in this Article of the difference between practicing entities and trolls.

122. If a patentee is interested only in collecting past royalties for infringement or a one-time payment for a future license, it will demand as much money as possible, subject only to the constraint that the defendant not go bankrupt and be unable to pay.

123. This is an example of "raising rivals' costs," a standard anticompetitive tactic. See, e.g., Thomas G. Krattenmaker \& Steven C. Salop, Anticompetitive Exclusion: Raising Rivals' Costs to Achieve Power over Price, 96 Yale L.J. 209, 230-42 (1986) (describing four methods used to raise rivals' costs). For a discussion of specific examples of so-called "patent bullying," see Sichelman, Vonage Trilogy, supra note 59 (manuscript at 7-18), which examines three patent infringement suits filed by Sprint, Verizon, and AT\&T against Vonage.

124. This is true only of practicing entities suing competitors or their customers or suppliers. As explained elsewhere, some practicing entities seek to monetize their patents irrespective of strategic considerations. See supra text accompanying notes 88-95 (explaining privateering, or spinning off of patents); infra text accompanying notes 129-130 (discussing various reasons for asserting patents). Those entities do not have the same incentive to raise rivals' costs, although they might not be regarded as "practicing entities" with respect to the patents in question.

125. A practicing entity might be inhibited in making particular, aggressive remedy arguments in a case in which it is asserting patents if it expects that those arguments could be used by others asserting patents against it in other litigation. A troll would not have a similar concern. Such inhibition is not likely to be significant or common, however, for several reasons. Any such inhibition would be likely to affect only one or a few of the arguments that a patent holder might make in any one case. An aggressive argument in one case will usually not harm the party in another case because the cases are likely to 
The substantial costs of patent litigation also enable these practices, especially when an established company sues a small startup, because a large company might use the cost of patent litigation itself as a tool to drive its smaller competitors out of business. ${ }^{126}$ Trolls have no similar incentive; they get paid more if the defendant stays in business and uses their patented technologies.

If patent assertions by practicing entities can generate more royalties than assertions by trolls and further strategic purposes as well, one might ask why trolls are able to buy patents in the secondary market in competition with practicing entities. There are two reasons. First, it does not follow that, because asserted patents are more valuable to practicing entities, portfolios are more valuable to them. ${ }^{127}$ Unless practicing entities decide to go into a new troll business, they are generally interested in buying only patents that are related to their product businesses or serve as strategic defensive assets that might further those businesses. The appetites of trolls are not so limited. To the extent that patent portfolios offered for sale include a wider range of patents than those in which a practicing entity is interested, the portfolio might be worth more to a troll, even if individual patents would be worth more to practicing entities. Second, in our experience, practicing entities are often parties to cross-licenses that cover later-acquired patents, so the value of new patents to practicing entities might be diminished to the extent that a practicing entity, unlike a troll, is unable to assert the new patents against existing licensees. ${ }^{128}$

\section{B. Trolls Behaving Badly}

There are other complaints about trolls that focus not on the fact that they are interested in only monetary compensation for their patents, but on how they seem to behave. In this section, we focus on the most commonly criticized troll behaviors. We consider whether trolls really behave differently from practicing entities and, if so, whether the ways in which they are different impose greater costs on technology users.

1. Royalty Stacking. - A practicing entity obtains or acquires patents to aid its product businesses: to prevent copying of its most valuable

differ in multiple respects. Further, an argument by a party in one case is unlikely to change the legal rules applicable to different parties suing it in other cases.

126. See, e.g., Faith Merino, When Big Brands Use Patents to Crush the Competition, VatorNews (Apr. 29, 2013), http://vator.tv/n/2f22 (on file with the Columbia Law Review) (describing 1-800-Contacts's use of patent litigation to harm smaller competitors).

127. On the value of portfolios as opposed to individual patents, see generally Parchomovsky \& Wagner, supra note 49, at 31-41 (describing benefits of scale and diversity of portfolios).

128. It might be imagined that a prohibition on patent acquisitions by trolls would steer patents toward practicing entities subject to cross-licenses and would thus diminish the costs imposed on technology users by those patents. But the licenses to the lateracquired patents are a bargained-for benefit and thus not costless to the licensees. 
product features, to use in barter with other practicing entities that hold patents on technologies it is using, or to impose costs on practicing entities selling competing products. ${ }^{129}$ Notably, the latter two purposes depend on whether the patents cover technologies used by other entities, not on whether the patent holder is practicing the patents. The first and third of these purposes entail asserting patents against actual or potential product business competitors; by contrast, the second is defensive and thus does not pose a risk to technology users, except to the extent they are contemplating asserting their patents against the patent holder. An individual technology user might have to worry about a few competing practicing entities with patents, or maybe even a few dozen, but the user usually knows who those competitors are and can assess the threat each might pose and how to respond. ${ }^{130}$

The universe of trolls that might assert patents against a technology user is not so limited. A troll might obtain or acquire any patent that it anticipates profitably monetizing, and it might assert patents against any technology user. At least in the IT industry, the universe of technology users against which a troll might assert patents is thus potentially much larger than the group of competitors against which a practicing entity is likely to assert its patents. As a result, IT companies face a seemingly endless stream of license demands and suits from patent trolls. ${ }^{131}$ There are at least several hundred trolls that actively sue companies, often asserting patents against an entire industry. ${ }^{132}$ And there are tens of thousands of potentially relevant patents that could be asserted at any time against a practicing entity in the IT industry. For example, Google's chief legal

129. Graham et al., supra note 76, at 1296-309 (describing varying motives startups have for obtaining patents). A practicing entity might also acquire a patent covering technologies that it is using in order to prevent another entity from asserting that patent against it, see id. at 1300-01, but that is best understood as a form of payment for infringing someone else's patent.

130. A practicing entity might also assert patents in order to monetize them for reasons unrelated to furthering their product businesses and thus might assert patents against technology users that are not competitors. Practicing entities whose product businesses have declined seem increasingly to do so, as the Texas Instruments, MOSAID, Tessera, and Nokia examples cited above illustrate. See supra notes 81-85 and accompanying text. But when they do, especially if they do not practice the asserted patents, they are acting as trolls.

131. Cf., e.g., Amrita Khalid, Tech Exec to Lawmakers: Patent Trolls 'a Massive Problem,' Hill: Hillicon Valley (Aug. 1, 2013, 3:13 PM), http://thehill.com/blogs/hilliconvalley/technology/315071-tech-exec-to-lawmakers-patent-trolls-keep-me-up-at-night (on file with the Columbia Law Review) (describing complaints about trolls to Congress by IT industry).

132. See, e.g., John A. Amster, The Patent Troll Toll, Intell. Prop. Mag., June 2013, at 33, 33, available at www.rpxcorp.com/siteFiles/News/9C3677C23C25889A23D3FC9BA 845B092.pdf (on file with the Columbia Law Review) (asserting there are more than 800 active trolls); cf. Allison et al., Trolls on Top, supra note 22, at 24-26 (finding trolls are responsible for more than $80 \%$ of assertions involving most-litigated patents); Chien, Patent Assertion Entities, supra note 46 (finding trolls filed $61 \%$ of the more than 5,000 patent suits in 2012). 
officer estimated more than two years ago that a smartphone uses technologies claimed by 250,000 different patents, ${ }^{133}$ the number today is probably larger. Cross-licensing with a competitor might have opportunity costs, but at least there is a defined universe of competitor patents, particularly in industries that have relatively few competitors. Add in trolls, and the universe can seem infinite.

This concern reflects a well-known problem in the IT industry that is often referred to as "royalty stacking"-the cumulative burden of the royalty obligations resulting from the large number of patents on technologies used in IT products. ${ }^{134}$ The substantive reason there are too many actual and potential trolls is that there are too many patents in the IT space. IT products are complex, multicomponent devices; making one might require integrating thousands of different ideas and parts. The Patent and Trademark Office (PTO), which issues patents, has been notoriously lax in granting patents on even small advances in the industry. ${ }^{135}$ And the IT industry is fast-moving; companies develop technology and bring it to market quickly, while utility patents take an average of more than three years from application to issuance and many take much longer. ${ }^{136}$ As a result, firms commonly invent technologies that are claimed by previously filed patent applications that have not yet resulted in issued patents and often have not yet even been published. Simultaneous invention and inadvertent infringement are thus ubiquitous. ${ }^{137}$ One study found that, in software and computer technology,

133. David Drummond, When Patents Attack Android, Google Official Blog (Aug. 3, 2011), http://googleblog.blogspot.com/2011/08/when-patents-attack-android.html (on file with the Columbia Law Review).

134. Lemley \& Shapiro, Patent Holdup, supra note 101, at 1993 (defining royalty stacking); cf. James Bessen \& Michael J. Meurer, Patent Failure: How Judges, Bureaucrats, and Lawyers Put Innovators at Risk 187-214 (2008) [hereinafter Bessen \& Meurer, Patent Failure] (arguing software patents are fundamentally different and more susceptible to abstract, broad claiming than other types of patents).

135. See, e.g., Adam B. Jaffe \& Josh Lerner, Innovation and Its Discontents 34-35 (2004) (" $[\mathrm{T}]$ he PTO has become so overtaxed, and its incentives have become so skewed towards granting patents, that the tests ... that are supposed to ensure that the patent monopoly is granted only to true inventors have become largely non-operative."); Lemley, Rational Ignorance, supra note 60, at 1495-96 \& nn.1-2 (collecting criticism of PTO and its approval of bad patents); see also Bessen \& Meurer, Patent Failure, supra note 134, at 238-39, 248 (suggesting PTO reject vague and abstract claims aggressively, and enforce stronger nonobviousness standard).

136. Average Patent Application Pendency, Patently-O Blog (Dec. 12, 2011, 6:26 AM), http://www.patentlyo.com/patent/2011/12/average-patent-application-pendency.html (on file with the Columbia Law Review); cf. Mark A. Lemley, Fixing the Patent Office, 13 Innovation Pol'y \& Econ. 83, 83-84 (2013) (presenting problems resulting from rapid issuance of bad patents); id. at 87-88 (noting delays in patent application process).

137. See, e.g., Mark A. Lemley, The Myth of the Sole Inventor, 110 Mich. L. Rev. 709, 712-33 (2012) [hereinafter Lemley, Myth] (describing overwhelming prevalence of simultaneous invention throughout history). 
roughly $97 \%$ of patent suits are filed against independent inventors, not copiers. ${ }^{138}$

In a world in which everyone can patent every little thing, royalty stacking is a fact of life. Troll suits bring into sharp focus the fact that much patent litigation does not represent a working market for ideas as much as a market for government-granted permissions to control or tax independently developed technologies. ${ }^{139}$ And the endless parade of trolls reflects the endless parade of patents granted on every new idea (and many not-so-new ideas) and the profit opportunities they provide. ${ }^{140}$

The underlying problem, then, is the number of patents that might read on a product and the number of different hands holding them. The question for present purposes is whether trolls exacerbate the problem in any significant way. ${ }^{141}$

Trolls do not directly affect the number of patents, except to the limited extent that they do research and generate their own patents. Most patents today are never enforced or licensed, ${ }^{142}$ and to some extent practicing entities rely on this fact and carry on their businesses without searching out all possibly relevant patents. ${ }^{143}$ It is likely, however, that trolls have increased the number of patents that are asserted because they have acquired patents from parties that were themselves unwilling or unable to assert them, perhaps because they lacked the resources or sophistication to do so. And, to the extent that trolls have stimulated the growth of a secondary market for patents, they might have increased

138. Cotropia \& Lemley, supra note 20 , at 1445-46.

139. Cf. Herbert Hovenkamp, Antitrust and the Movement of Technology, 19 Geo. Mason L. Rev. 1119, 1144-45 (2012) ("Intellectual property law today is in a position similar to that occupied by antitrust several decades ago. The law is far too captured by interest groups that represent producers rather than consumers, and that profit from excessive regulation in the name of IP protection." (footnote omitted)).

140. In theory, ignoring transaction costs, the number of patents would not be a problem if the cost of infringing each patent did not exceed the economic value of the patented technology. As explained above, however, those costs commonly do exceed the value of the patented technologies. See supra Part II.A (discussing costs of patent assertion). Moreover, transaction costs incurred in the efforts to enforce and license the multitude of patents are themselves enormous. See Lemley, Rational Ignorance, supra note 60 , at 1507 (estimating actual cost of negotiating license to be $\$ 50,000$ to $\$ 100,000$ ).

141. We address in Part II.B.2, infra, the issue of aggregation or dispersion of patents, and address here the issue of the number of patents.

142. Lemley, Rational Ignorance, supra note 60, at 1507 (estimating only $5 \%$ of patents are ever litigated or licensed for royalty).

143. Mark A. Lemley, Ignoring Patents, 2008 Mich. St. L. Rev. 19, 21-22 (noting many companies do not search for patents in advance of starting research or filing patent application). Given the multitude of possibly relevant patents, searching even for just those already published and attempting to obtain licenses or design around them would be prohibitively costly and, as a practical matter, would be impossible without bringing the innovation process to a near standstill. See id. at 25-26 (noting time and cost of finding patents and negotiating licenses, as well as difficulties arising from lack of knowledge regarding legal rights at time of investment decisions). And, of course, there is no way to search for patent applications that have not yet been published. 
incentives for would-be inventors to seek patents and therefore might indirectly have caused an increase in the total number of patents. ${ }^{144}$

In addition, the largest trolls, which have well-developed programs for buying large numbers of patents, might benefit from economies of scale in acquiring widely dispersed patents that have not already been assembled into large portfolios. Practicing entities, which are generally interested in a narrower range of patents that can be used in aid of their product businesses, might be less able to realize such scale economies. These economies of scale could result in the monetization of patents that would otherwise remain unenforced because of the cost of identifying and transferring those patents into the hands of entities able to monetize them. Therefore, by being able to take advantage of such economies of scale, the largest trolls could cause an increase in the number of asserted patents and could thereby exacerbate the royalty stacking problem. But it is not clear that such economies of scale have a significant effect on the number of patents that are enforced. Practicing entities generally hold larger patent portfolios than most trolls and might therefore also be able to take advantage of economies of scale. Further, even small trolls have been able to obtain financing for their litigation and patent acquisition. ${ }^{145}$ The prevalence of small trolls and individuals who enforce their own patents ${ }^{146}$ suggests that, if there are economies of scale to patent assertion, the minimum efficient scale is quite small.

In any event, it is not clear that monetizing otherwise-ignored patents is itself a bad thing. Some would applaud the unearthing of otherwise-overlooked patents as long as the inventors get paid, on the ground that it tends to increase incentives for innovation despite also increasing technology users' costs. ${ }^{147}$ One might reject that view on the grounds that there are more patents than needed to induce the under-

144. Some authors have encouraged owners of patents to dust them off and assert them. See, e.g., Kevin G. Rivette \& David Kline, Rembrandts in the Attic: Unlocking the Hidden Value of Patents 122-24 (2000) (arguing unenforced patents comprise \$1 trillion of untapped asset wealth for U.S. businesses). On the role of trolls as market makers, see, for example, James F. McDonough III, Comment, The Myth of the Patent Troll: An Alternative View of the Function of Patent Dealers in an Idea Economy, 56 Emory L.J. 189, 210, 213 (2006) ("When a patent dealer joins the market, the market dynamics change. The market moves toward a more centralized or 'dealer' market in which the patent dealer becomes a focal point for transactions.").

145. See, e.g., Bruce D. Sunstein, Funding Patent Assertion Litigation 2-6 (2005) (unpublished manuscript), available at http://www.sunsteinlaw.com/media/funding patent_assertation_BDS.pdf (on file with the Columbia Law Review) (discussing alternatives for funding patent lawsuits).

146. See, e.g., Allison et al., Trolls on Top, supra note 22, at 20-26 (finding mostlitigated patents were disproportionately owned by small companies that failed to commercialize their technology).

147. See, e.g., McDonough, supra note 144, at 223 (arguing "presence of patent dealers in the market allows individual inventors and small entities to gain easy access to the patent market"). 
lying inventions, ${ }^{148}$ that excessive damages awards ensure adequate incentives for invention even if only some patents are enforced, that many patents do not serve the knowledge transmission function intended by the patent laws, ${ }^{149}$ or perhaps that patents should not be enforced against innocent infringers. ${ }^{150}$ We have sympathy for some of these views. ${ }^{151}$ But those are really objections to the patent system, not to trolls.

148. A recent study estimates that no more than $25 \%$ of the sums collected from technology users by trolls comprise "payments to inventors" and thus concludes that trolls do not "increase innovation incentives." Bessen \& Meurer, Direct Costs, supra note 10 (manuscript at 26-27, 49 tbl.5). If these data are correct, they might seem to support an inference that trolls, including those that are themselves innovators, increase the costs of technology users without furthering the interests of patent law in promoting innovation. But the Bessen and Meurer study is not sufficient to justify that inference. In the first place, the study does not show comparable data for practicing entities to use as a benchmark. Apple, for instance, invests heavily in $\mathrm{R} \& \mathrm{D}$, but it is also sitting on over $\$ 100$ billion in cash. See Romain Dillet, Apple Now Has \$137.1 Billion in Cash, More than HP's Annual Revenue and Vietnam's GDP, TechCrunch (Jan. 23, 2013), http://techcrunch.com/ 2013/01/23/apple-now-has-many-billions-in-cash-more-than-hps-annual-revenue-and-vietn ams-gdp/ (on file with the Columbia Law Review). It is not clear that, if Samsung has to pay Apple an additional $\$ 1$ billion, the result will be increased $R \& D$ by Apple. If trolls return $25 \%$ of revenues to innovators, but practicing entities return even less-something this study does not illuminate-the Bessen and Meurer observation might serve as an indictment of the efficacy of the patent system as a whole, but not of trolls in particular. Moreover, the relevant question is not whether a large percentage of what trolls collect funds innovative activity (which goes to the efficiency of trolls as enhancers of innovation incentives), but whether trolls increase or decrease the amounts that fund and thus might induce such activity. Others have set forth methodological concerns with the Bessen and Meurer study, on which we express no opinion. See, e.g., Schwartz \& Kesan, supra note 10 (manuscript at 5-19).

In any event, the success of trolls appears to have stimulated aggressive buying and asserting of patents by both new trolls and practicing entities. The resulting increased competition in the secondary market for patents is likely to reduce or eliminate the arbitrage opportunity of which early trolls took advantage, see Hagiu \& Yoffie, supra note 7 , at 52 ("The arbitrage opportunities available to nonpracticing entities are sizable."), and bid up the prices of patents in the secondary market relative to their value in the hands of parties better able to assert them. This will, in turn, result in innovators realizing an increasing portion of the sums collected from technology users.

149. For criticism of the disclosure theory of patents, see Lemley, Myth, supra note 137 , at 745-49, which notes that scientists no longer get information from patents because of vague disclosures and delayed issuance of patents.

150. For arguments that innocent infringement should not be unlawful, see, for example, Stephen M. Maurer \& Suzanne Scotchmer, The Independent Invention Defence in Intellectual Property, 69 Economica 535, 540-42 (2002) (asserting independent invention reduces waste); Carl Shapiro, Prior User Rights, 96 Am. Econ. Rev. 92, 95 (2006) (promoting recognition of prior use rights); Vermont, supra note 18, at 493-500 (arguing recognition of independent invention defense is economically efficient). But see Mark A. Lemley, Should Patent Infringement Require Proof of Copying?, 105 Mich. L. Rev. 1525, 1527-32 (2007) (critiquing proposals for independent invention defense).

151. One interesting recent experiment simulating patent systems with varying remedies suggests that innovation and welfare increase as patent protection decreases. See Andrew W. Torrance \& Bill Tomlinson, Property Rules, Liability Rules, and Patents: One Experimental View of the Cathedral, 14 Yale J.L. \& Tech. 138, 143 (2011) (finding highest 
It might be objected that, even if trolls are not the cause of the problem, eliminating or restraining trolls might reduce the number of patents asserted and therefore serve as a second-best solution to the problem of royalty stacking. That might be true if the patents that trolls assert would remain ignored in the absence of trolls, but that seems unlikely. Trolls might have been the pioneers, but they have not lacked for emulators. There is increasing and now widespread recognition that patents have value. ${ }^{152}$ Practicing entities are spending billions of dollars to acquire patents and are establishing entities to acquire other patents so that they do not fall into the hands of rivals, trolls, or other firms likely to assert them. ${ }^{153}$ And when practicing entities wind up owning patents that they cannot put to good use, they are increasingly eager to sell them to others that can. ${ }^{154}$ It is probably too late to put the genie back in the bottle and return to the days when practicing entities could count on most patents being ignored.

There is little reason to believe that, as long as there is an abundance of patents that can be used to generate revenues, buy patent peace, or tax competitors, only trolls will try to profit from them. Restricting trolls might diminish secondary market transactions and, in that way, ameliorate to some extent the problem of royalty stacking; but it would do so by inhibiting the enforcement of patents without regard to their quality. Restricting patent assertion by practicing entities would have the same effect. Much more direct and effective solutions to the royalty stacking problem would be to raise the bar to patentability, thereby reducing the number of weak patents rather than simply reducing the number of patents across the board; to reduce excessive patent remedies, thereby reducing both incentives to find and assert otherwise-ignored patents

amounts of "innovation, productivity, and social utility" occurred when no patent remedy was available).

152. See, e.g., Rivette \& Kline, supra note 144, at 3 ("[S]ome of the world's most successful companies ... regard patent strategy as a new core competency of the modern enterprise and an important factor in their success."); see also Decker, supra note 81 (discussing shift of many companies in view toward value of patents).

153. This is, in part, the business model of RPX Corp. See Reducing Patent Risk, RPX Corp., http://www.rpxcorp.com/index.cfm?pageid=9 (on file with the Columbia Law Review) (last visited Sept. 3, 2013) ("[E] ach patent in the RPX portfolio [is] one less patent that could be used in an infringement assertion...."). Some claim it was part of the original purpose of Intellectual Ventures as well. See, e.g., Henry Delcamp \& Aija Leiponen, Patent Acquisition Services: A Market Solution to a Legal Problem, or Nuclear Warfare? 10-12 (2013) (unpublished manuscript), available at http://eship.dyson. cornell.edu/wp-eship/wp-content/uploads/Delcamp_Leiponen_CMR.pdf (on file with the Columbia Law Review) (arguing Intellectual Ventures evolved from defensive aggregator into troll).

154. See Jackie Hutter, The Coming Explosion of the Patent Monetization Market: Brought to You by Open Innovation and What Needs to Happen in Order to Speed Up the Process, IP Asset Maximizer Blog (Oct. 21, 2009), http://ipassetmaximizerblog.com/ ?p=844 (on file with the Columbia Law Review) ("[T] here are many more potential sellers of unused patent rights than there are buyers today."). 
and the costs to technology users of assertions of those patents; and to try to concentrate those patents in fewer hands, thereby directly reducing the royalty stacking problem. ${ }^{155}$ That last solution leads to the next complaint about trolls - that they aggregate too many patents.

2. Patent Aggregation. - A common complaint about trolls, especially about aggressive pioneers like Intellectual Ventures, is that they aggregate large numbers of patents and that the aggregation of large numbers of patents in the hands of a single entity overwhelms alleged infringers by giving them little choice but to pay for a license for the bundle of patents even if they think the individual patents at issue are invalid or not infringed. ${ }^{156}$

To be sure, acquisition and aggregation of patents can injure competition and harm technology users in the same way that acquisitions of other types of assets can be harmful. ${ }^{157}$ Aggregators can combine substitute or competing technologies and thus make it more difficult for technology users to bargain for low royalties by threatening to use other technologies, and aggregators can transfer ownership of a patent covering a technology needed by one firm or its customers to a competitor of that firm. ${ }^{158}$ Problems of the first type seem to have been uncommon, at least in the IT industry, where independent invention is ubiquitous, ${ }^{159}$ and in any event there is no reason to think that aggregations by trolls are more likely to give rise to these problems than aggregations by practicing entities. Problems of the second type depend on the strategic incentives of the patent holder in the markets in which patented tech-

155. See infra Part III (discussing proposals in greater detail).

156. See, e.g., Letter from Ken Wasch, President, Software \& Info. Indus. Ass'n (SIIA), to Legal Policy Sec., Antitrust Div., U.S. Dep't of Justice 3-4 (Apr. 5, 2013) [hereinafter Letter from SIIA], available at http://www.ftc.gov/os/comments/pae/pae0042.pdf (on file with the Columbia Law Review) ("As a [troll] adds more and more patents to its portfolio, the incentive for their [sic] victims to defend themselves in litigation diminishes to a point where the only rational response is to capitulate to the [troll's] demands."). For an argument that the PTO should change its fee structure to discourage aggregation because of these complaints, see David S. Olson, Removing the Troll from the Thicket: The Case for Enhancing Patent Maintenance Fees in Relation to the Size of a Patent Owner's Non-Practiced Patent Portfolio 22-35 (Bos. Coll. Law Sch., Legal Studies Research Paper No. 303, 2013), available at http://ssrn.com/abstract=2318521 (on file with the Columbia Law Review).

157. On the antitrust treatment of patent acquisitions, see generally, for example, 1 Herbert Hovenkamp et al., IP and Antitrust $§ \S 14-1$ to -4 (2d ed. 2010 \& Supps. 2010, 2011 $\&$ 2012).

158. Intellectual Ventures, for instance, offers an IP for Defense program that will loan out patents to companies that want to counterclaim against a plaintiff suing them. See IV Signs New IP for Defense Customer, Intellectual Ventures: IV Insights Blog (June 28, 2011), http://www.intellectualventures.com/insights/archives/iv-signs-new-ip-fordefense-customer (on file with the Columbia Law Review) (noting "customers can purchase patents from our portfolio of more than 35,000 IP assets to support counter-assertion and encourage efficient negotiations that reduce liabilities").

159. Cotropia \& Lemley, supra note 20, at 1458-59 (discussing low rates of copying in most industries, with exception of pharmaceuticals). 
nologies are used and are thus unlikely to arise with trolls, which generally profit most by licensing all competitors in a market.

The complaint about trolls seems to have little to do with such ordinary antitrust concerns, perhaps because antitrust lawyers counsel against aggregating substitutes or because there are few opportunities in the IT industry to obtain market power in a technology market by combining competing patents. Instead, the complaint about trolls is that they aggregate large numbers of complementary patents. This complaint raises two questions: Do trolls aggregate complementary patents more than practicing entities, and is that bad?

a. Do Trolls Aggregate Patents More than Practicing Entities? - While some trolls, like Intellectual Ventures, MOSAID, and Acacia, aggregate large numbers of patents, ${ }^{160}$ many-probably most-do not. Many trolls are very small entities operated by a handful of individuals, although they might be funded by others. ${ }^{161}$ Indeed, the complaint that there are too many trolls itself implies that there is a great dispersion of patents; that complaint is, at the very least, in tension with the complaint that trolls aggregate too many patents, because the more patents that are aggregated, the fewer separate licenses are required.

The extent to which large patent portfolios are assembled by practicing entities also varies substantially, and the differences between practicing entities and trolls here are often more illusory than real. While small practicing entities often have small portfolios that reflect the scope of their product businesses, large practicing entities in many industries (notably IT) hold huge numbers of patents. ${ }^{162}$ These practicing entities license their patents by the hundreds or thousands, and they typically license either their entire portfolio or all patents needed to clear rights in a particular field, often without even specifying exactly which patents are covered. Like trolls, they often seem indifferent to the scope and validity of any single patent in the portfolio, and their licenses often include patents that do not yet exist but that might be added to the portfolio later. ${ }^{163}$

160. See supra notes 47-50 and accompanying text (describing troll aggregation business model and providing estimates of portfolio size for some aggregators).

161. See supra notes 145-146 and accompanying text (noting small trolls enforce patents and have variety of funding mechanisms).

162. IBM, for example, has the world's largest patent portfolio and aggressively licenses its patents. Press Release, IBM, IBM Tops U.S. Patent List for 20th Consecutive Year: IBM Inventors Deliver Innovation in Emerging Areas of Tech (Jan. 10, 2013), www03.ibm.com/press/us/en/pressrelease/40070.wss (on file with the Columbia Law Review) (highlighting IBM's record-setting 6,478 patents in 2012).

163. License agreements are almost always confidential, but the statements in this paragraph are consistent with our experience. For a discussion of portfolio licenses, see generally Parchomovsky \& Wagner, supra note 49. For a discussion of efforts to cover some types of future inventions and future patents under licensing agreements, and the disagreements over the scope of such clauses, see Hal Milton, "Improvements" in Patent Licenses: Presumptions and Clauses Derived from Case Law, 34 AIPLA Q.J. 333 (2006), 
Further, while practicing entities generally assemble patent portfolios that are related to their product businesses, trolls are not so restricted and often assemble portfolios of patents covering a wider range of technologies. ${ }^{164}$ Thus, even if trolls have more patents than practicing entities, they might not have more complementary patents reading on the products of individual technology users, and their aggregation of patents thus might not affect the costs they impose on individual technology users.

Nor can trolls be distinguished from practicing entities on the ground that they aggregate patents by purchasing them from third parties. ${ }^{165}$ Equating trolls with all entities that purchase the patents they assert is both over- and underinclusive. While some patent trolls are in the business of buying patents in order to license or assert them, most definitions of trolls include a variety of other NPEs, including universities, individuals, and failed companies asserting their own technology against those that succeeded in the marketplace. ${ }^{166}$ Moreover, trolls are hardly the only ones buying patents in order to assert them in litigation. Smartphone companies alone have spent perhaps $\$ 15$ billion in the past three years buying patents (and in some cases whole companies) in order to better position themselves to sue each other, ${ }^{167}$ likely far more than trolls have spent. Indeed, trolls sometimes sell patents to practicing entities. ${ }^{168}$ More generally, looking forward, as long as aggregating complementary patents is a profitable strategy, there is no reason to think that firms that use technology will remain less interested than trolls in pursuing that strategy. It is not clear that trolls aggregate complementary patents more than practicing entities.

b. Is Patent Aggregation Bad? - Aggregation of complementary patents in the hands of a single entity could have three effects on technology users' costs. ${ }^{169}$ Only one is likely to be important.

which explores the meaning of contract clauses that grant licensees the right to a patented invention and improvements thereof.

164. See Ewing \& Feldman, supra note 12, at 5 (noting Intellectual Ventures and its subsidiaries hold over 8,000 U.S. patents); see also id. at 3-15 (studying Intellectual Ventures in detail).

165. For one argument criticizing purchasing of patents by trolls, see Adi Kamdar, Another Bill to Fix the Patent Troll Problem ... Well, Part of It, Elec. Frontier Found.: Deeplinks Blog (May 13, 2013), https://www.eff.org/deeplinks/2013/05/another-bill-fixpatent-troll-problem-well-part-it (on file with the Columbia Law Review) (calling practice of trolls buying up patents "deplorable").

166. See, e.g., Allison et al., Trolls on Top, supra note 22, at 10 tbl.1 (breaking patent plaintiffs into twelve different categories, only one of which is practicing entity).

167. See supra note 61 and accompanying text (describing recent patent purchases by practicing entities).

168. See Ewing \& Feldman, supra note 12, at 10 (documenting sales from Intellectual Ventures shell companies to Verizon and Vlingo).

169. For discussion of a fourth, indirect effect, see supra Part II.B.1. That is the possibility that aggregation enables the realization of economies of scale that lead to an 
First, aggregation could increase technology users' costs by sheltering weak patents from challenge. The logic here is straightforward and can be illustrated by an oversimplified example. If a patent holder asserts one patent, and the chance that, if challenged in litigation, the patent will be found invalid or not infringed is, say, $70 \%$, the alleged infringer is likely to litigate the claim or at least to use the threat of doing so to negotiate a settlement that reflects the $70 \%$ chance that it will prevail in litigation. The alleged infringer will likely do the same if five different patent holders each assert a different patent against the same product with the same chance of being found invalid or not infringed. But if one patent holder asserts all five patents against that product, and if the probabilities of a finding of invalidity or noninfringement of the various patents are independent of one another, the alleged infringer will have less than a $17 \%$ chance of avoiding a finding that it infringed a valid patent. Once the patent holder's portfolio includes dozens of complementary patents, the alleged infringer has little practical ability to avoid having to pay for a license. ${ }^{170}$

The real world is more complicated. For both substantive and forensic reasons, it is unlikely that the probabilities that multiple patents asserted by a single entity will be found to be invalid and not infringed will be completely independent, especially if the patents are asserted in a single lawsuit. Among other things, closely related patents might face overlapping arguments about invalidity in light of prior art; patents that read on similar technologies might face overlapping arguments as to whether the products at issue actually infringe the patents; and judges and juries are likely to be influenced by general factors, such as which of the litigants they trust, that could have a common impact on the litigation of most or all of the patents-in-suit. ${ }^{171}$ Still, as the example in the preceding paragraph illustrates, the sheltering effect of patent aggregation is exhausted, as a practical matter, at relatively modest levels of patent aggregation. In an IT world in which patent holders typically have portfolios of hundreds of patents and assert them against complex

increase in the aggregate number of asserted patents. The discussion in this section concerns the effects of the aggregation or dispersion of a fixed number of patents.

170. See Parchomovsky \& Wagner, supra note 49, at 32-37 (discussing scale advantages of large portfolios); cf. Michael Risch, Patent Portfolios as Securities, 63 Duke L.J. 89, 99-101 (2013) [hereinafter Risch, Patent Portfolios] (discussing examples of patent aggregation as litigation strategy). If the alleged infringer cannot afford the millions of dollars normally required to see patent litigation to conclusion, it might not litigate the assertion of even a single patent. For that infringer, even in the example in this Article, the aggregation of patents is likely to have little if any incremental effect of sheltering weak patents.

171. Allison and Lemley found that patents asserted together generally stand or fall together, although they did not differentiate independent patents from those in the same family. See John R. Allison \& Mark A. Lemley, Empirical Evidence on the Validity of Litigated Patents, 26 AIPLA Q.J. 185, 245 (1998) (finding asserted patents were often related to each other and usually were held valid or invalid together). 
products that use thousands of different technologies, incremental changes in the degree of patent aggregation are unlikely to have a material effect on the extent to which patents are sheltered from effective challenge.

Second, aggregations of patents can reduce transaction costs by combining multiple patents into a single license or lawsuit and could in that way benefit technology users. But, like the patent sheltering effect, this effect is likely for all practical purposes to be exhausted at low levels of aggregation. The costs of litigating or negotiating a license for small numbers of patents can be large relative to the value of the patents, but those transaction costs become relatively insignificant when portfolios of dozens or hundreds of patents are involved. The transaction cost benefits of aggregation beyond that point are likely to be immaterial.

It is only the third effect of patent aggregation-reducing the number of entities with which a practicing entity must deal- that is likely to be important. Concentration of patents in the hands of fewer owners (whether trolls or practicing entities) can reduce the extent of royalty stacking by reducing an economic externality that tends to increase royalty costs for technology users and by reducing the effects of strategic uses of patents to increase the costs for competitors of the patent holders.

The costs imposed on technology users by royalty stacking depend on two factors: the number of required licenses or alternatives thereto, and the cost of the licenses. All other things equal, patent aggregation reduces the number of entities holding and asserting patents. Patent aggregation can thus reduce the number of licenses a technology user needs by enabling broad portfolio licenses instead of multiple licenses with multiple patent holders. Broad licenses can reduce transaction costs. They can also reduce per-patent costs because, by avoiding multiple separate assertions, they reduce the number of times the patents in the portfolio command excessive damages or royalties properly attributable to other components. ${ }^{172}$

More important, by reducing the number of entities holding and asserting complementary patents, patent aggregation can ameliorate what economists call the double marginalization or "Cournot complements" problem. ${ }^{173}$ As explained above, patent holders are often

172. See supra notes 113-119 and accompanying text (discussing problems with patent damages law).

173. See generally Augustin Cournot, Researches into the Mathematical Principles of the Theory of Wealth 99-116 (Nathaniel T. Bacon trans., Augustus M. Kelley Publishers 1971) (1838) (explaining Cournot complements problem). For discussions of the Cournot problem in the context of patents, see Lemley \& Shapiro, Patent Holdup, supra note 101, at 2013-16; Carl Shapiro, Navigating the Patent Thicket: Cross Licenses, Patent Pools, and Standard Setting, in 1 Nat'l Bureau of Econ. Research, Innovation Policy and the Economy 119, 122-24 (Adam B. Jaffe et al. eds., 2001) [hereinafter Shapiro, Navigating the Patent Thicket]. 
in a position like that of firms that have market power in that they can command damages or royalties for their patents in excess of their value. ${ }^{174}$ If they use that power to extract running or per-unit royalties, they will do so only up to the point that, by raising price, they cause a reduction in the number of units of the infringing products sold sufficient to offset the price increase and reduce their profits. If one firm sells all of the inputs (in this case, patents) needed for the product, it will take into account the full reduction in patent royalties attributable to a reduction in the number of units sold in determining the profit-maximizing price. If, on the other hand, multiple firms sell the various inputs (patents), each will bear only a part of the reduction in royalties attributable to a reduction in the number of units. As a result, economic theory teaches, the aggregate royalty that will be charged by the multiple firms will exceed the royalty that would be charged by a single firm selling all the inputs. This leads to what is sometimes called the "anticommons" problem, in which dividing property into too many pieces inefficiently reduces use of that property. ${ }^{175}$

The double marginalization problem can be substantial. ${ }^{176}$ It does not depend on the various patent holders having different incentives, such as the possibility that practicing entities will have strategic incentives to seek to impose supramonopoly prices on their competitors. Instead, it reflects a simple proposition: Complementary inputs cost less when they are acquired from a single supplier with market power than when the same inputs are acquired from multiple suppliers, each of which has market power. Aggregation of patents that are likely to confer some degree of market power in the hands of a single patent holder is therefore likely, all other things equal, to reduce technology users' costs.

The converse is also true. If aggregating patents tends to reduce the royalty stacking/double marginalization problem, disaggregating complementary patents worsens that problem. ${ }^{177}$ Aggregation trolls often

174. See supra Part II.A.2 (discussing how practicing entities are likely to get excessive damages awards); supra Part II.B.1 (explaining royalty stacking).

175. See generally Michael A. Heller \& Rebecca S. Eisenberg, Can Patents Deter Innovation? The Anticommons in Biomedical Research, 280 Science 698 (1998) (explaining anticommons problem and how it arises through patent issues in biomedical research); Michael A. Heller, The Tragedy of the Anticommons: Property in the Transition from Marx to Markets, 111 Harv. L. Rev. 621, 660-77 (1998) (discussing anticommons property generally).

176. See, e.g., Timothy F. Bresnahan \& Peter C. Reiss, Dealer and Manufacturer Margins, 16 RAND J. Econ. 253, 262-67 (1985) (evaluating effects of "successive monopoly model" in automobile market); Timothy F. Bresnahan, The Right Remedy 41-43 (Stanford Law Sch., John M. Olin Program in Law \& Econ. Working Paper No. 233, 2002), available at http://ssrn.com/abstract=304702 (on file with the Columbia Law Review) (explaining double marginalization problem in context of Microsoft Office and Windows).

177. But cf. Alberto Galasso \& Mark Schankerman, Patent Thickets, Courts, and the Market for Innovation, 41 RAND J. Econ. 472, 499-501 (2010) (arguing fragmentation of patent rights drives quicker settlements of patent disputes). Even granting Galasso and 
divide up their patents into different holding companies for licensing and litigation. ${ }^{178}$ They even put complementary patents in different entities. Practicing entities also spin off patents to multiple entities and sometimes, as explained above, create new trolls for the purpose of asserting their patents. ${ }^{179}$ Even acquisitions by coalitions, like that which formed Rockstar Bidco, ${ }^{180}$ allocate rights to the patents to different entities for strategic reasons.

On the surface, deliberate disaggregation might seem puzzling because the theory of double marginalization teaches not only that the input buyers' cost will be lower with aggregation, but also that input suppliers' aggregate profits from asserting or licensing the patents will generally be higher if complements are aggregated and supplied by a single entity. ${ }^{181}$ There are, however, aspects of the patent system that can make disaggregation profitable to patent holders and especially burdensome to technology users. The most important is probably that owners believe that damages awards are likely to be greater in aggregate if multiple patent assertions are made by different entities than if they are made by a single entity. Because patent damages are likely to include more than the incremental value of the patented technology itself, i.e., to include some product value not properly attributed to the asserted patent, the patent holder is more likely to be able to "double dip" into that excess value by multiple assertions than if it asserts all its patents in a single case. ${ }^{182}$ Indeed, the patent holder may have to file different cases;

Schankerman's conclusion that parties settle patent disputes more quickly when faced with a Cournot complements problem, their data do not demonstrate either that the total cost associated with litigation has declined or that the settlements avoid the Cournot complements problem. It may well be that technology users faced with a flood of patent suits that could derail their product pay a supracompetitive price in an early settlement to avoid that risk. See Lemley \& Shapiro, Patent Holdup, supra note 101, at 2008-10 (discussing difficulty of negotiating favorable settlements in face of holdup). It may also be the case that Galasso and Schankerman's data reflect the growing presence of bottom-feeder trolls (which have a strong interest in early settlement) in fragmented industries. Cf. supra notes 44-46 and accompanying text (defining bottom-feeder trolls).

178. Ewing and Feldman find over 1,200 Intellectual Ventures shell companies, and suspect there are many more. Ewing \& Feldman, supra note 12, at 5. By 2009, an undisclosed number of Acacia subsidiaries had control over 100 patent portfolios. Press Release, Acacia Research Corp., Acacia Research Reports First Quarter 2009 Financial Results (Apr. 23, 2009) (on file with the Columbia Law Review); see also Chien, Arms Race, supra note 41, at $319 \&$ n.142 (describing Acacia and its numerous shell companies).

179. See supra notes 88-95 and accompanying text (describing patent privateering).

180. See McMillan, supra note 94 (discussing creation of Rockstar Bidco).

181. See Shapiro, Navigating the Patent Thicket, supra note 173, at 122-23 (offering aggregation as solution to inefficiencies of double marginalization); Bresnahan, supra note 176 , at 42 (explaining assumptions in double marginalization theory).

182. This assumes that damages law works to prevent the holder of a single essential patent from getting the entire value of the product even though it might be said in some sense to hold a bottleneck monopoly. To the extent the court awards the entire value of a multicomponent product to a single patentee, using the entire market value rule or an overbroad injunction, "double dipping" becomes irrelevant unless subsequent courts 
no court is likely to allow hundreds of patents to be litigated in a single case. ${ }^{183}$ But if the patents are owned by the same entity, that entity might have only limited success asserting different patents against a single product in multiple cases, both because judges and juries will be unsympathetic to such "double dipping" and because it might be difficult to resolve the first case except with some kind of portfolio license that will preclude or restrict subsequent assertions of other patents. Seen in this light, selling some of the relevant patents to others that will be less constrained in their ability to assert those patents in a subsequent proceeding makes sense. And if the patents are transferred to a subsidiary or other entity under common control, the transferor can both increase the damages award by "double (or more) dipping" and ensure that the total of the damages and royalties recovered from the technology user will not exceed the amount that maximizes the patent holders' profits. ${ }^{184}$

Disaggregation of patents can increase technology users' costs in another way as well. The highest bidders for at least portions of a dispersed portfolio, and therefore the likely buyers, might be practicing entities that want to use the patents to raise the costs of their rivals and are willing to pay more for the patents for their strategic value than other potential buyers that are interested solely in generating royalties. And multiple practicing entities that share a strategic objective to increase a competitor's costs might divide a portfolio precisely in order to facilitate double marginalization and thereby increase the competitor's costs. Disaggregation can therefore both exacerbate the double marginalization problem and facilitate the use of patents for anticompetitive strategic purposes.

Given the potential of patent disaggregation to further anticompetitive strategic purposes, it might seem odd that practicing entities often sell patents to trolls rather than to other practicing entities and, indeed, set up trolls for this purpose. It is possible that the patent seller-the patent privateer-really controls the troll and the deal is a sham. That is unlikely to be common, however, because such a sham transaction would be too likely to be detected and punished, either by the target or by anti-

ignore that award and independently award extra damages. See Lemley, Distinguishing Lost Profits, supra note 100, at 662-64 (criticizing entire market value rule); Love, Patentee Overcompensation, supra note 101, at 273-78 (arguing entire market value rule overcompensates patent holders).

183. See Risch, Patent Portfolios, supra note 170, at 140 ("Portfolio owners cannot realistically sue on more than a few patents at a time ....").

184. Such "double dipping" will succeed only if resolution of early patent assertions does not require licensing of both the patents held by the entity making the early assertions and the patents held by other, commonly controlled entities. As a practical matter, avoiding such licensing might require that the identity of the other commonly controlled entities and their patents be concealed, and the desire to avoid such licensing might therefore explain in part why trolls like Intellectual Ventures and Acacia have large numbers of undisclosed subsidiaries that own different patents. 
trust law. ${ }^{185}$ A more plausible explanation is that the privateer is able as a practical matter to control or constrain the incentives of the troll. It might do so by contract or by selling patents that are already licensed to all but a few users of the patented technologies and thus directing the troll's attention to the seller's targets. For instance, if Microsoft were to sell to a troll a smartphone patent that was already licensed to Apple and to users of the Microsoft and Blackberry operating systems, the only significant remaining target for such a patent would be phones using the competing Android operating system.

Further, the patent-releasing practicing entity does not want its patents to be in the hands of another practicing entity whose strategic incentives are not perfectly aligned with its own. While a patent troll might want to maximize its own revenue rather than the cost imposed on a competitor, it might still be more likely to use the patents to impose a tax on that competitor than would a practicing entity with different or unpredictable strategic incentives. For example, Company $A$ might not want to strengthen company $B$, even if $B$ shares $A$ 's concern about company $C$, if $B$ has other strategic interests that are adverse to $A$ 's. And $A$ might fear that the interests of $B$ and $C$ will be aligned in the future, even if they are not at present.

The fact that privateering almost always transfers patents from practicing entities to trolls complicates our analysis because it seems at first blush to suggest that trolls are the problem. In fact, however, it is notable that both trolls and practicing entities engage in privateering; ${ }^{186}$ disaggregation thus seems to be the problem regardless of the type of entity that engages in it. This is true, fundamentally, because when multiple complementary patents are held by a single entity, the cost to technology users is generally less than when they are held by multiple entities.

3. Litigation Costs. - Despite the factors discussed above, the idea that dealing with troll patents is more costly than dealing with practicing entities seems to resonate with those facing troll suits. Practicing entities know that the only thing the troll wants is money and that there is generally no cross-license or other business deal that can prevent litigation or effect a quick settlement of an otherwise costly lawsuit. By contrast, practicing entities often enter into cross-licenses instead of litigating and

185. Indeed, privateering is sometimes punished by targets, which sue the seller when they believe that the seller has explicitly aimed privateering at them. Google, for instance, reportedly sued BT for patent infringement after BT released patents to trolls that then sued Google. Charles Arthur, Google Countersues BT over Patents, Guardian (Feb. 14, 2013, 6:56 AM), http://www.guardian.co.uk/technology/2013/feb/14/googlecountersues-bt-over-patents (on file with the Columbia Law Review).

186. Intellectual Ventures, for instance, regularly spins patents out of its portfolio to other trolls that then assert those patents in court. Ewing \& Feldman, supra note 12, at 1314 (giving examples of Intellectual Ventures's transfers of patents for this purpose). 
thus avoid the rather substantial costs of litigation. ${ }^{187}$ In addition, litigation is generally much less costly to trolls than to practicing entities because trolls have less complex business operations-and thus fewer witnesses and far fewer documents-to produce in discovery; ${ }^{188}$ because of these asymmetrical costs, critics suspect that trolls are more willing to prolong and broaden patent litigation. ${ }^{189}$

In fact, however, there is little reason to think that troll suits are, suit for suit, more costly to litigate than are suits by practicing entities. While trolls can impose substantial litigation costs, the most important-and expensive-litigation in the IT industry has come not from trolls but from practicing entities. One of us has estimated, for example, that the parties to the more than sixty smartphone patent lawsuits previously filed around the world have already spent perhaps $\$ 1$ billion in legal fees alone. ${ }^{190}$ Some lawsuits, such as Oracle's action against Google, likely ran up huge legal bills despite leading to no significant damages award. ${ }^{191}$

A patent assertion imposes litigation costs regardless of who the plaintiff is, but there is reason to think that the costs are likely to be larger, at least on a per-suit basis, if the plaintiff is a practicing entity. The larger average size of practicing entities and the fact that they have sales and product information create a likelihood of broader and more costly

187. See supra Part II.A.1 (discussing cross-licensing behavior and its opportunity costs). The median cost of a patent suit worth more than $\$ 25$ million is $\$ 5.5$ million in legal fees. See AIPLA, Report, supra note 45, at 34 .

188. See U.S. Gov't Accountability Office, GAO-13-465, Intellectual Property: Assessing Factors That Affect Patent Infringement Litigation Could Improve Patent Quality 3 \& n.8, 10 (2013), available at http://www.gao.gov/assets/660/657103.pdf (on file with the Columbia Law Review) (noting lower discovery costs for trolls, and how this provides leverage against practicing entities); Colleen V. Chien \& Michael J. Guo, Does the U.S. Patent System Need a Patent Small Claims Proceeding? (Santa Clara Univ. Sch. of Law, Legal Studies Research Paper No. 10-13, 2013), available at http://papers.ssrn.com/ abstract=2249896 (on file with the Columbia Law Review); Chien, Patent Assertion Entities, supra note 46 (noting trolls face lower costs of assertion because they do not have indirect costs and pay lawyers on contingency).

189. See, e.g., Letter from SIIA, supra note 156, at 4-5 ("The [troll] business model is to make the litigation as expensive and disruptive as possible ...."). Some academics dispute that trolls prolong litigation. See Chien, Of Trolls, supra note 23, at 1605 (noting troll suits finished in average of 9.1 months while "sport of kings" suits finished in average of 14 months); supra notes 44-46 and accompanying text (noting bottom-feeder troll model seeks quick settlement).

190. See Jennifer Smith, Check, Please: Experts Say Apple, Samsung Face Sky-High Legal Fees, Wall St. J.: Law Blog (Aug. 24, 2012, 7:53 PM), http://blogs.wsj.com/law/ 2012/08/24/check-please-experts-say-apple-samsung-face-sky-high-legal-fees/ (on file with the Columbia Law Review) (quoting Mark A. Lemley).

191. See, e.g., Oracle Am., Inc. v. Google Inc., No. C 10-03561 WHA, 2012 WL 1945496, at *2, *7 (N.D. Cal. May 30, 2012) (upholding jury verdict finding Google did not infringe Oracle's patents); see also Joe Mullin, Oracle v. Google: No Patent Infringement Found, Ars Technica (May 23, 2012, 2:08 PM), http://arstechnica.com/techpolicy/2012/05/google-v-oracle-no-patent-infringement-found/ (on file with the Columbia Law Review) (noting six-week trial ending with minimal damages payments to Oracle). 
discovery for all parties. Further, suits involving practicing entities often include additional issues involving injunctions and lost profits damages and are more likely to include counterclaims. ${ }^{192}$

To be sure, trolls are likely to bring suits that practicing entities would not pursue because their asymmetric exposure to discovery burdens and their reliance on contingent fee lawyers mean they bear lower litigation costs than the practicing entities they sue. ${ }^{193}$ This is especially true of bottom-feeder trolls. The sheer number of troll suits might outweigh the fact that individual practicing entity cases are more expensive, but cases that a practicing entity would not find economic to bring are more likely to settle early and thereby to avoid large litigation costs, since the point of the bottom-feeder business model is to collect avoided litigation costs.

In general, there is little reason to think that trolls are less likely to settle patent disputes than are practicing entities. ${ }^{194}$ To the contrary, trolls are royalty seekers. Because their patents are their primary assets, trolls will often be less willing to risk a determination of invalidity, and thus more willing to settle, than royalty-seeking practicing entities. In addition, when practicing entities use patents not to raise revenues, but to protect their products from copying or to strategically impose costs on competitors, they might be less likely to settle except on terms that are onerous to the defendant. ${ }^{195}$ That does not mean troll suits are not costly, but on the whole they are likely to settle earlier and cost less than practicing entity suits.

4. Improper or Aggressive Patent Assertion Tactics. - A final possibility is that trolls are willing or able to assert patents in circumstances in which, for economic or reputational reasons, practicing entities would not. Some bottom-feeder trolls seem more willing than practicing entities to

192. See supra notes 100-108 and accompanying text (discussing differences in injunctive relief and lost profits between practicing entity and troll suits). Because trolls make no products, they cannot be sued for patent infringement, so the patent infringement counterclaim-common in disputes between practicing entities-is absent from troll suits.

193. Cf. supra note 189 and accompanying text (highlighting asymmetric litigation costs for trolls and practicing entities). On the rise of contingent fee patent litigation, see generally David L. Schwartz, The Rise of Contingent Fee Representation in Patent Litigation, 64 Ala. L. Rev. 335 (2012); Ronen Avraham \& John M. Golden, From PI to IP: Yet Another Unexpected Effect of Tort Reform 4-5, 20 (Univ. of Tex. Sch. of Law, Law \& Econ. Research Paper No. 211, 2013), available at http://papers.ssrn.com/abstract= 1878966 (on file with the Columbia Law Review) (highlighting how personal injury lawyers, who work on contingency fee, switched to IP litigation after tort reform).

194. In fact, a recent study found little difference in the willingness of trolls and practicing entities to settle their cases, with an only slightly higher percentage of trolls settling their suits. Allison et al., Patent Quality, supra note 16, at 694 (finding trolls settled $89.6 \%$ of suits while practicing entities settled $86.6 \%$, and difference was not statistically significant).

195. See supra notes 123-126 and accompanying text (discussing possibility of practicing entity seeking supracompetitive running royalties on competitors' products). 
engage in aggressive assertion practices to extract money with little regard for whether the patents are valid or even infringed. ${ }^{196}$ Both practicing entities and trolls often prefer to assert their patents downstream against companies that make expensive multicomponent products, rather than against companies that make less costly components, even if the patented technology is used only in the components. ${ }^{197}$ But trolls are more likely to threaten large numbers of end users with small-damages suits that the end users often cannot afford to litigate. ${ }^{198}$ Trolls might do so to avoid having a court examine the validity of the asserted patents and whether the technology user is infringing them, and thus to be able to collect royalties even for patents that are invalid, not infringed, or both. ${ }^{199}$ And while practicing entities often like to draw attention to their large patent holdings in order to deter assertions against them by other practicing entities, trolls seem more likely to

196. Cisco recently filed a lawsuit against a troll that, Cisco alleged, "engaged in a nationwide pattern and scheme to ... extort money" from "thousands of businesses" by claiming infringement of patents to which the troll knew the businesses were already licensed in the expectation that those businesses would settle rather than incur the legal costs needed to defend the baseless claims. Cisco alleged that the troll's conduct violated the federal Racketeer Influenced and Corrupt Organizations Act. Plaintiffs' Amended Complaint at 9, In re Innovatio IP Ventures, LLC Patent Litig., 921 F. Supp. 2d 903 (N.D. Ill. 2013) (No. 11 C 9308), 2012 WL 8500139; cf. Consumer Protection Complaint at 1, State v. MPHJ Tech. Invs., LLC, No. 282-5-13Wncv (Vt. Super. Ct. May 8, 2013) (alleging troll engaged in unfair and deceptive acts by sending threatening and misleading letters to small technology users that did not have resources to defend against patent assertion).

197. Asserting patents against component suppliers generally reduces transaction costs because there are usually far fewer of them using any particular patented technologies. But patent holders often prefer the more costly downstream assertions because they anticipate that flaws in patent damages law will enable them to obtain larger damages awards and royalties when they assert against more expensive products and can claim to be entitled to a percentage of a larger revenue base. Once a patent holder licenses a component supplier, exhaustion principles preclude it from recovering additional royalties for the same alleged infringement by downstream entities. See supra note 62 (discussing patent exhaustion principles).

198. See, e.g., Tim Steller, Local Firm Faces Heat of Patent Enforcer, Ariz. Daily Star (Feb. 17, 2013, 12:00 AM), http://azstarnet.com/news/local/tim-steller-local-firm-facesheat-of-patent-enforcer/article_456aaa3f-893e-5465-8e93-73c849415fad.html (on file with the Columbia Law Review) (highlighting troll suit over use of photocopier). See generally Allison et al., Patent Quality, supra note 16 (finding trolls file more lawsuits on mostlitigated patents than practicing entities).

199. See, e.g., Exec. Office of the President, Patent Assertion and U.S. Innovation 6 (2013) [hereinafter White House Report], available at http://www.whitehouse.gov/sites/ default/files/docs/patent_report.pdf (on file with the Columbia Law Review) (noting trolls threaten to sue, even without evidence of infringement, to get settlement); Chien, Startups, supra note 33 (manuscript at 4) ("Innovatio LLC has sued small coffee shops and hotels that use wifi, and Project Paperless LLC has sued small businesses due to their use of digital scanners." (footnote omitted)). Indeed, Chien found that $40 \%$ of small businesses had been targeted for using technology provided by another. Id. For proposals to deal with end-user suits, see, for example, James C. Yoon, PowerPoint: Expanding the Customer Suit Exception in Patent Law (2012), http://www.jdsupra.com/legalnews/ expanding-the-customer-suit-exception-in-28989/ (on file with the Columbia Law Review). 
conceal their patent holdings. ${ }^{200}$ Concealing patents has two effects. First, trolls might thereby be more able to defer licensing discussions until technology users have developed and invested in products that include the patented technologies and are thus less able to switch to alternatives. ${ }^{201}$ Second, concealing patent holdings may enable trolls to resist demands that patent assertions be resolved by effective portfolio licenses, and thereby to increase the likelihood of multiple, "double dipping" assertions. In short, trolls appear more likely than practicing entities to engage in abusive conduct that exploits flaws in the patent system, in particular the abundance of bad patents and the excessive damages awards.

One reason that practicing entities might be less likely to engage in such tactics is that they might be concerned about disrupting valuable business relationships. As explained above, however, the explicit or implicit use of business relationships to deter or resolve patent assertions is not costless to the technology users. ${ }^{202}$

In addition, a practicing entity might be reluctant to engage in transparently rapacious patent monetization, not because it fears disruption of specific, identifiable commercial relationships or opportunities, but because it fears the general consequences of being regarded as an opportunist that exploits other firms' vulnerabilities for short-term gain. Practicing entities might fear that being regarded that way could harm their businesses in unforeseen ways in the future. In this situation, a technology user might be able to take a "free ride" on the practicing entity's general reputational concerns because it would not have to jeopardize any particular business relationship in order to benefit from the practicing entity's inhibitions.

It seems likely that practicing entities have in the past been more concerned than trolls about such reputational matters. It remains to be seen whether these reputational inhibitions will dissipate in the future as practicing entities become more accustomed to aggressive patent monetization and more aware of the revenue opportunities available to them. Practicing entities have certainly become more aggressive in general in asserting and monetizing their patents in recent years, not only by engaging in privateering but also by seeking to enforce patents

200. See Justin R. Orr, Note, Patent Aggregation: Models, Harms, and the Limited Role of Antitrust, 28 Berkeley Tech. L.J. 525, 543-44 (2013) (discussing troll attitude toward secrecy).

201. See Lemley \& Shapiro, Patent Holdup, supra note 101, at 1995 (“[T] he patent holder can engage in strategic delay or concealment, knowing it will be in a stronger bargaining position once the downstream firm has already designed its product incorporating the patented feature."); Orr, supra note 200, at 543-44 (noting trolls "may also benefit from concealing their patent interests until after a technology has been accepted and locked in within an industry").

202. See supra Part II.A.1.a (discussing impact of business relationship on assertion behavior). 
against industry standards despite commitments to license those patents on reasonable terms. ${ }^{203}$ It is possible that, as "everyone does it," the stigma associated with privateering and other forms of aggressive patent assertion will disappear. Or, on the contrary, the growth of patent assertions may cause plaintiffs perceived as trolls to be even more reviled, so that practicing entities remain reluctant to bring weak cases or litigate too aggressively.

\section{Balancing Costs and Benefits}

Overall, it seems difficult to make the case that trolls impose greater costs on technology users than do practicing entities as a general matter. When opportunity costs are taken into account, barter with other practicing entities is as costly as paying cash to resolve patent assertions by trolls, except in situations in which (1) business dealings are used in barter, (2) the patent holder has more to lose from a cessation of those dealings than does the technology user, and (3) the technology user is otherwise unable to extract full value from the dealings. Payments to trolls could impose greater economic costs than barter arrangements if the payments take the form of running royalties, but that appears to be uncommon. Some aspects of the patent system tend to make patent assertions by practicing entities more costly to technology users, all other things equal, than patent assertions by trolls.

203. E.g., Microsoft Corp. v. Motorola, Inc., 696 F.3d 872, 889 (9th Cir. 2012); Broadcom Corp. v. Qualcomm Inc., 501 F.3d 297, 314-15 (3d Cir. 2007); Apple, Inc. v. Motorola Mobility, Inc., No. 11-cv-178-bbc, 2012 WL 5416941, at *1 (W.D. Wis. Oct. 29, 2012); Apple, Inc. v. Samsung Elecs. Co., No. 11-CV-01846-LHK, 2012 WL 2571719, at *26-*28 (N.D. Cal. June 30, 2012); Microsoft Corp. v. Motorola, Inc., 864 F. Supp. 2d 1023, 1032 (W.D. Wash. 2012); Apple, Inc. v. Motorola, Inc., No. 1:11-cv-08540, 2012 WL 1959560, at*12 (N.D. Ill. May 22, 2012). For a table listing all FRAND litigation, see Jorge L. Contreras, Fixing FRAND: A Pseudo-Pool Approach to Standards-Based Patent Licensing, 79 Antitrust L.J. (forthcoming 2013) (manuscript app. 1 at 41-43), available at http://papers.ssrn.com/abstract=2232515 (on file with the Columbia Law Review). For criticism of these enforcement efforts and discussion of FRAND-specific problems, see, for example, Joseph Farrell et al., Standard Setting, Patents, and Hold-Up, 74 Antitrust L.J. 603, 616-18 (2007) (outlining how industry standard context exacerbates holdup problems); Lemley \& Shapiro, A Simple Approach, supra note 108 (manuscript at 4-14) (suggesting rules for standard-setting organizations that would reduce patent litigation); Doug Lichtman, Understanding the RAND Commitment, 47 Hous. L. Rev. 1023, 1033-34 (2010) (explaining heightened cost of ex post negotiations in standard-setting regime); Joseph Scott Miller, Standard Setting, Patents, and Access Lock-In: RAND Licensing and the Theory of the Firm, 40 Ind. L. Rev. 351, 358 (2007) (arguing FRAND precludes patent holdups and permits beneficial bargaining); Mark R. Patterson, Commentary, Antitrust and the Costs of Standard-Setting: A Commentary on Teece \& Sherry, 87 Minn. L. Rev. 1995, 2000-01 (2003) (asserting standardization leads to interdependent demand from potential licensees, and potentially higher royalties); Mark R. Patterson, Inventions, Industry Standards, and Intellectual Property, 17 Berkeley Tech. L.J. 1043, 1056-78 (2002) (suggesting method for licensing patented inventions in standards); Mark R. Patterson, Leveraging Information About Patents: Settlements, Portfolios, and Holdups, 50 Hous. L. Rev. 483, 513-22 (2012) (discussing problem of deception in standard setting). 
Trolls are unlikely to impose greater litigation costs on technology users, and they do not have the same incentives as practicing entities to raise rivals' costs. To the extent that trolls aggregate large numbers of patents, they likely reduce the costs to technology users. ${ }^{204}$ The advent of trolls has probably led to the monetization of patents that would otherwise have been ignored, but it is not clear that that is a bad thing as a matter of public policy or that the broadening of the secondary market for patents that trolls have stimulated will remain unique to trolls in the future. ${ }^{205}$

Trolls do seem more likely to engage in "bottom feeding" and in abusive litigation practices, such as naming large numbers of defendants in individual lawsuits or suing downstream end users that are unable as a practical matter to litigate in their defense. ${ }^{206}$ Because trolls are less likely to be inhibited by reputational concerns, these differences will probably endure, at least to some extent. But these types of conduct do not seem either unique to trolls or engaged in by all trolls. In some circumstances, practicing entities engage in their own forms of abusive conduct, such as bullying smaller competitors by using the cost of litigation to disadvantage them.

Perhaps the greater hostility to patent assertions by trolls than to assertions by practicing entities reflects a judgment, not just about the relative costs imposed on technology users by trolls and practicing entities, but also about the social value contributed by each. Trolls may do less good for society, so even when their patents and practices are not worse than those of practicing entities, we are less willing to put up with those practices when they are undertaken by trolls. ${ }^{207}$

There is something to the objection that trolls add little value. The world benefits from inventions that are actually deployed in the real world. Trolls rarely invent, and by definition they do not practice the patented technologies. And even when they do invent, the evidence suggests that they rarely engage in real technology transfer. Mostly, they sue others that independently invented the same thing. ${ }^{208}$ As a general matter, only practicing entities both invent something and turn it into a product that makes society better off.

But we are not persuaded that this difference suffices to make the case against trolls. It is not the companies themselves that the law should

204. See supra Part II.B.2.b (discussing benefits of aggregation).

205. See supra notes 147-155 and accompanying text (discussing value of monetizing otherwise-ignored patents and noting troll behavior is now emulated by practicing entities).

206. See supra Part II.B.4 (discussing litigation practices of trolls).

207. See White House Report, supra note 199, at 3-7 (arguing trolls overassert patents)

208. See Cotropia \& Lemley, supra note 20, at 1451 (finding copying to have been established in 1.76\% of cases studied); Lemley, Myth, supra note 137, at 712-33 (providing examples of simultaneous independent invention throughout history). 
care about, but rather their patents and, more specifically, their patent licensing and litigation practices. The question is not whether we are better off overall having a practicing entity like Apple than a troll like Acacia; surely we are. The right question is whether society is better off when patents are held and enforced by trolls than when they are held and enforced by practicing entities. That is far from clear. Practicing entity lawsuits and licensing programs can be at least as costly as those of trolls.

It might be thought that the costs resulting from patent assertions by practicing entities are less objectionable because they are more likely to drive innovation. But patents that end up in the hands of trolls arguably provide at least as much incentive for innovation ex ante as do patents in the hands of practicing entities. Troll patents were usually once startup or university patents. ${ }^{209}$ Startups and universities generally have relatively small patent portfolios, and the prospect of a patent is thus more likely to have a significant effect on their incentives for innovation than on the incentives of large companies with thousands of issued patents and a multitude of business incentives to invest in R\&D. ${ }^{210}$ Moreover, it is not clear that we need so many patents in the hands of either practicing entities or trolls in order to create optimal incentives for innovation, at least in the IT industry. Many patentees (not just trolls but practicing entities, too) do not develop the technology behind their patents; they patent ideas that never make it to market, ${ }^{211}$ or they claim their patents so broadly that they encompass features that are never brought to market. ${ }^{212}$

Perhaps the argument for preferring practicing entities to trolls is that practicing entities will invest their returns from litigation in more $\mathrm{R} \& \mathrm{D}$, while trolls will just use them to get rich. That is certainly the stereotype, and it is true that practicing entities do more $\mathrm{R} \& \mathrm{D}$ than most trolls. But that is not the whole story. In the first place, some trolls do invest in R\&D, at least to some extent; Intellectual Ventures, for example,

209. See Risch, Myths, supra note 95, at 484-89 (describing origination of troll patents).

210. See Rajesh K. Chandy \& Gerard J. Tellis, The Incumbent's Curse? Incumbency, Size, and Radical Product Innovation, J. Marketing, July 2000, at 1, 12 (finding "small firms and nonincumbents are slightly more likely to introduce radical product innovations than large firms and incumbents," but noting this trend has been in decline since World War II).

211. See, e.g., Cotropia, supra note 19, at 107-13 (discussing role of early filing in underdevelopment of patented technologies); Ted Sichelman, Commercializing Patents, 62 Stan. L. Rev. 341, 343 (2010) [hereinafter Sichelman, Commercializing Patents] ("About half, probably more, of all patented inventions in the United States are never commercially exploited.”).

212. See Lemley, Return of Functional Claiming, supra note 28 (manuscript at 19) (noting software "claims are effectively unlimited as a matter of structure" (emphasis omitted)). 
employs a cadre of inventors funded by its patent licensing activities. ${ }^{213}$ Moreover, not even the most innovative practicing entities spend all new revenue on $\mathrm{R} \& \mathrm{D}$. Apple, for instance, has well over $\$ 100$ billion in the bank; ${ }^{214}$ it is presumably already making all the R\&D investments that it regards as worthwhile and would be unlikely to increase its R\&D investments in response to increased patent licensing revenue. Also, to the extent that troll patents are acquired from others rather than generated by the trolls' own R\&D, trolls do cause money to flow to inventors; the fact that the inventors chose to sell their patents suggests they believed that was their profit-maximizing course. In this way, trolls provide both increased incentives and increased funding for R\&D by others.

There is one theory of patents that would justify favoring practicing entities over trolls: commercialization theory. If one believes that the patent system is intended, not to encourage invention, but to encourage companies to take existing inventions to market, ${ }^{215}$ one might be more willing to put up with harm caused by the patent assertion practices of companies that actually commercialize inventions than with the same harm from a troll. But we are skeptical that the point of the patent system is or should be to provide benefits and incentives to the first commercializer rather than to inventors. One of us has criticized commercialization theory in detail elsewhere, calling it fundamentally antimarket. ${ }^{216}$ In any event, the regulatory system needed to implement a commercialization theory would look rather different from the current patent system. ${ }^{217}$

Trolls and practicing entities, then, both impose costs. Practicing entities may offer more benefits to society, but not through patent

213. Jim Kerstetter \& Josh Lowensohn, Inside Intellectual Ventures, the Most Hated Company in Tech, CNET (Aug. 21, 2012, 6:57 AM), http://news.cnet.com/8301-13578_357496641-38/inside-intellectual-ventures-the-most-hated-company-in-tech/ (on file with the Columbia Law Review).

214. Chuck Jones, How Much Extra Cash Does Apple Really Have?, Forbes (Dec. 12, 2012, 10:15 AM), http://www.forbes.com/sites/chuckjones/2012/12/12/how-much-extracash-does-apple-really-have/ (on file with the Columbia Law Review).

215. See Michael Abramowicz, The Danger of Underdeveloped Patent Prospects, 92 Cornell L. Rev. 1065, 1106 (2007) (identifying concern over sufficiently incentivizing commercialization); Michael Abramowicz \& John F. Duffy, Intellectual Property for Market Experimentation, 83 N.Y.U. L. Rev. 337, 339-40 (2008) (discussing interplay of intellectual property rights and market experimentation); F. Scott Kieff, Property Rights and Property Rules for Commercializing Inventions, 85 Minn. L. Rev. 697, 710 (2001) ("[A]lthough a simple reward for inventive effort might provide adequate incentives for invention itself, the nascent invention may never reach a single consumer without... incentives to commercialize."); Edmund W. Kitch, The Nature and Function of the Patent System, 20 J.L. \& Econ. 265, 275-80 (1977) (exploring role played by patent system in securing returns on investment); Sichelman, Commercializing Patents, supra note 211, at 396 (proposing creation of "commercialization patents").

216. Mark A. Lemley, Ex Ante Versus Ex Post Justifications for Intellectual Property, 71 U. Chi. L. Rev. 129, 130-32 (2004).

217. Id. at 131; Lemley, Myth, supra note 137, at 738-45 (explaining why patents would not solve failure of invention commercialization). 
enforcement. When it comes to patent enforcement, it is hard to conclude that trolls cost society more than practicing entities.

\section{WHAT TROLLS CAN TEACH}

None of this is to deny that patent trolls appear to present a serious and growing problem. But we believe trolls are a symptom of the real problems, not their cause. Trolls are opportunists that exploit flaws in the patent system. The growth of patent trolls, coupled with the costs of practicing entity licensing and litigation, suggests systemic problems that are not limited to trolls. ${ }^{218}$ Trying to identify and target particular bad actors might be better than doing nothing at all, but in a larger sense it is missing the forest for the trolls.

For one thing, the analysis above suggests that many of the complaints about trolls as the source of problems with the patent system have little substance. While trolls do appear more likely to engage in abusive conduct like nuisance-value litigation, not all trolls engage in such conduct, and practicing entities also engage in their own forms of abusive conduct. ${ }^{219}$

In addition, it is not clear how one could write a rule that would both be sensible and distinguish in a meaningful way between trolls and practicing entities. To be sure, the extreme case of an entity that does nothing but buy and assert patents is easy to classify as a troll. But what if that entity engaged in a modest but not trivial amount of R\&D, especially R\&D that entailed use of technologies claimed by patents in its portfolio ${ }^{220}$ Or what if that entity operated a modest product business, or hoped to do so in the future? It would not be easy to distinguish that entity from a practicing entity that owned and asserted patents it did not practice. A rule that defined a troll as an entity that does nothing but buy and assert patents or that earns more than $X$ percent of its revenues from, or incurs more than $Y$ percent of its costs in, patent assertion activities might be coherent. But the larger the percentage limit-and thus, the smaller the universe of entities defined as trolls- the less commensurate the rule would be with the scope of the perceived problems. Conversely, the smaller the percentage, the more likely the rule would be-and be perceived as-arbitrary (because the line between troll and nontroll would likely have little correlation with the entities' proclivity to

218. See Anne Layne-Farrar, The Brothers Grimm Book of Business Models: A Survey of Literature and Developments in Patent Acquisition and Litigation 1, 22-24 (Mar. 21, 2012) (unpublished manuscript), available at http://ssrn.com/abstract $=2030323$ (on file with the Columbia Law Review) (discussing similarities between trolls and "giants" and "dwarves"-practicing entities that also assert their patents for revenue).

219. See supra Part II.B.4 (critiquing claim trolls engage in abusive practices more often than practicing entities).

220. Cf. Lemley, Universities, supra note 42, at 615-19 (noting universities are nonmanufacturing entities and describing concerns about university patent holding). 
engage in objectionable conduct) and susceptible to transacting around (by, for example, investing in product businesses).

One can imagine a different kind of legal rule that would address trolls indirectly. It would not distinguish between patent holders based on the nature of the entity but rather would permit firms to assert only patents that they actually practice. Such a rule would put an end to trolls, but it would have a multitude of problems. Among other things, it would increase litigation costs by requiring evidence regarding whether the patent holder is actually practicing the asserted patent; impair the secondary market for patents even when they are coupled with real technology transfer; make it more difficult for practicing entities to obtain cross-licenses by effectively removing the threat that they might assert patents they do not practice; penalize firms that are engaged in genuine innovation but find it most efficient to license others to commercialize their inventions; make it impossible for patent holders to sue to prevent infringement for the benefit of their licensees who, if nonexclusive, could not themselves assert the licensed patents; ${ }^{221}$ distort the innovation process by creating artificial incentives for parties to include patented technologies in their products or otherwise to practice their patents; and reduce incentives for and thus the incidence of patent aggregation. ${ }^{222}$

A somewhat different rule would prohibit the assertion of patents other than in aid of the product businesses of the patent holder or its licensees by deterring or offsetting patent claims by others or, perhaps, by raising rivals' costs. This rule, too, would both increase litigation costs by introducing additional and perhaps more difficult issues and impair the secondary market for patents. It would also enable firms to use patented technologies invented by others without paying appropriate compensation for them as long as those firms did not compete with or assert patents against the patent holder, and it would reduce the number of entities able to assert patents against any one technology user and thus encourage the aggregation of patents in fewer hands. ${ }^{223}$

221. Under the Federal Circuit's standing rules, only patent owners and a subset of exclusive licensees can sue for patent infringement. See Xuan-Thao Nguyen, Patent Prudential Standing, 21 Geo. Mason L. Rev. (forthcoming 2013) (manuscript at 2-3), available at http://papers.ssrn.com/abstract $=2321808$ (on file with the Columbia Law Review) (finding "patent prudential standing" requires plaintiff to possess "all the substantial rights to the patent").

222. As previously discussed, contrary to common belief, patent aggregation can be beneficial. See supra Part II.B.2.b.

223. Judge Posner recently suggested that "the troll problem" could be solved by barring enforcement of a patent that "was not reduced to practice within a specified time after the patent was granted.” Richard Posner, Patent Trolls, Becker-Posner Blog (July 21, 2013, 5:12 PM), http://www.becker-posner-blog.com/2013/07/patent-trollsposner.html (on file with the Columbia Law Review). For suggestions along similar lines, see, for example, Sichelman, Commercializing Patents, supra note 211, at 400-11 (proposing new "commercialization" patent available for making and selling novel products). The rule proposed by Judge Posner would very likely reduce patent royalty and litigation costs 
Rather than targeting trolls themselves as the problem, it is better to think of trolls as opportunists that exploit and thereby illuminate flaws in the patent system, and to think of the hostility to trolls as a reflection of larger problems with the patent system. Patent reform can then be focused more appropriately on the systemic issues that give rise to patent trolls-on granting patents only to those who develop nonobvious inventions and providing remedies for infringement that are commensurate with the scope of the invention.

In this Part, we suggest some lessons from patent trolls for reform of the patent system as a whole. As a preface, trolls point up the industryspecific nature of the patent system. Dan Burk and Mark Lemley have written about this extensively elsewhere. ${ }^{224}$ The fact that trolls are ubiquitous in the IT industry and quite rare everywhere else suggests that the problems that create troll opportunities are, at the very least, much greater in that industry. ${ }^{225}$ It provides support for our suggestion that Cournot complements, and, more broadly, the large number of complementary patents arguably infringed by individual IT devices, are part of the problem. If strategic behavior were the only explanation, we would expect to see more troll suits in the pharmaceutical and biotechnology industries.

Because many of the problems we have identified are predominantly IT problems, we should exercise care in making sweeping changes to patent policy that might have different effects in different industries. Other industries might or might not need reform too, but the lessons trolls can teach resonate primarily in the IT industry. Nonetheless,

incurred by technology users, and it would reduce incentives for accumulating patents for the purposes of either asserting them against third parties or using them in barter with other patent holders. The rule would apply to practicing entities as well as trolls because it depends directly on the patent, not the patent holder. But the rule would have some of the problems of commercialization theory, see supra notes 215-217 and accompanying text, and it would raise difficult litigation issues about whether, when, and by whom a patent was commercialized. It would also distort the innovation process by reducing the incentive to invent things that the inventor could not easily commercialize, whether because the cost of manufacturing was high or because the inventor was in an unrelated field.

224. See generally Burk \& Lemley, Patent Crisis, supra note 104, at 38-48 ("Different industries vary greatly in how they approach innovation, the cost of innovation, and the importance of innovation to continued growth. For innovation, one size definitely does not fit all.”); Dan L. Burk \& Mark A. Lemley, Is Patent Law Technology-Specific?, 17 Berkeley Tech. L.J. 1155 (2002) (describing how general legal standards of patent law are adapted to different industries); Dan L. Burk \& Mark A. Lemley, Policy Levers in Patent Law, 89 Va. L. Rev. 1575 (2003) (highlighting patent theories as applied to different industries).

225. For a historical perspective on trolls in other industries, see generally Steven W. Usselman, Regulating Railroad Innovation: Business, Technology, and Politics in America, 1840-1920 (2002) (discussing patent trolls in multicomponent railroad industry); Gerard N. Magliocca, Blackberries and Barnyards: Patent Trolls and the Perils of Innovation, 82 Notre Dame L. Rev. 1809 (2007) (discussing litigation over patented farm tools in nineteenth century). 
because the IT industry accounts for more than half of all patent applications filed today, ${ }^{226}$ we cannot dismiss its problems as isolated or insignificant.

The first lesson trolls can teach is that, at least in the IT industry, there are too many patents claiming too broadly. The bottom-feeder and troll aggregation models work because trolls can be confident that there are always another hundred patents out there that can be made to read on any defendant's product. And practicing entities can buy patent portfolios to assert against competitors (or spin patents out to others) for the same reason.

Some of this is a function of the nature of products in the IT industry, which is more likely than other industries to involve combining many different components into a single product. But some of the problem can be laid at the feet of the patent system. Software patent claims, for example, are often ridiculously overbroad because they are based on claims to the goal being achieved, not the program or approach that achieved that goal-what one of us has called "functional claiming."227 Patent claims should be commensurate with the actual invention. When they are broader than that, the predictable result is many people suing and claiming that they own the new technology because they invented an instantiation of the technology, no matter how different the alleged infringer's instantiation actually looks.

Theoretically, such broad functional claiming should mean that almost all of the patents in each space are invalid. It is perfectly plausible, for example, that ten people each independently invented and patented ten different software mechanisms for creating dynamic linked lists, but it is not possible that ten different people are each entitled to patent the concept of the dynamic linked list itself. If we are to allow first inventors extremely wide scope in their patent claims, the corollary is that all follow-on patents claiming broad scope are invalid. More generally, we might need either to enforce the existing obviousness standard more rigorously or to raise the standard so that we are protecting true inventions rather than straightforward improvements. Doing so would help stanch the endless flow of patents-to trolls and practicing entities-that threaten those who make products in the IT industry.

226. Mark A. Lemley \& Bhaven Sampat, Is the Patent Office a Rubber Stamp?, 58 Emory L.J. 181, 195 (2008).

227. Lemley, Return of Functional Claiming, supra note 28 (manuscript at 2) (noting patents are often written in broad, goal-based terms). Chien and Karkhanis find that patent trolls are more likely than practicing entities to assert software patents with functional claims. In their study, $100 \%$ of software patent trolls used functional claiming, but only $50 \%$ of practicing entities did so. Colleen V. Chien \& Aashish R. Karkhanis, Functional Claiming and Software Patents 40 (Santa Clara Univ. Sch. of Law, Legal Studies Research Paper No. 06-13, 2013), available at http://papers.ssrn.com/abstract=2215867 (on file with the Columbia Law Review). 
Functional claiming is not the only cause of the excessive number of patents in the IT industry. Patents are intended to induce invention, not patenting itself, and to facilitate technology transfer through publication. But when simultaneous invention and inadvertent infringement are ubiquitous, the system serves neither purpose. Invention is driven mainly by commercial need-thus ubiquitous simultaneous invention-and it proceeds at a pace that is not influenced by the teachings of published patents, which are too numerous to be studied except by litigators and patent buyers and which are often published far too late to affect subsequent invention in the fast-moving IT world. The standards of obviousness and novelty need to be applied more rigorously by the PTO and the courts to reduce the number of patents whose issuances do not serve the purposes of the patent laws.

Second, patent remedies do not reflect the realities of patent practice. Royalty stacking is a very real problem in the IT industry. ${ }^{228}$ As long as hundreds or thousands of patents claim to read on each new product, patent remedies must take account of the fact that there are always more patents waiting in the wings to lay claim to revenues from that product.

Injunctions and exclusion orders should generally be used only to exclude those who infringe major inventions. They should not be used to exclude products based on infringement of a minor component or to give patent holders (whether trolls or practicing entities) leverage to extract excess royalties from implementers. eBay was a major step forward in this respect. ${ }^{229}$ Once courts began inquiring into the adequacy of legal remedies and the hardship imposed by an injunction, they started to deny injunctions to trolls in almost all cases. ${ }^{230}$ More recently, courts have also begun denying injunctions to practicing entities where the patent covers only a minor part of the defendant's product, ${ }^{231}$ though it is not

228. See supra notes 131-139 and accompanying text (defining royalty stacking and explaining why it is particularly prevalent in IT industry).

229. eBay Inc. v. MercExchange, L.L.C., 547 U.S. 388, 393-94 (2006) (finding no automatic injunctive relief for patent infringement); see also id. at 396-97 (Kennedy, J., concurring) ("When the patented invention is but a small component of the product the companies seek to produce and the threat of an injunction is employed simply for undue leverage . . ., legal damages may well be sufficient to compensate for the infringement and an injunction may not serve the public interest.").

230. See Chien \& Lemley, supra note 27, at 2 ("[D] istrict courts rarely grant injunctions in patent infringement cases to [trolls].”).

231. E.g., Apple Inc. v. Samsung Elecs. Co., 695 F.3d 1370, 1374-76 (Fed. Cir. 2012) (finding where only few features of many-featured product infringe, patent holder must prove causal nexus between particular feature and irreparable harm); Apple Inc. v. Samsung Elecs. Co., 909 F. Supp. 2d 1147, 1153 (N.D. Cal. 2012) (finding none of Apple's patents cover particular features driving consumer demand, and thus no irreparable harm to Apple). 
clear that approach will prevail. ${ }^{232}$ But the ITC still grants exclusion orders even for minor components, so the problem of holdup from injunctions has not been solved. ${ }^{233}$

Restricting injunctions may avoid the worst parts of the holdup problem discussed above, ${ }^{234}$ but it will not solve it entirely. Our traditional measure of patent damages is not well suited to dealing with the royalty stacking problem because it does not adequately account for the fact that royalties are generally calculated long after technology users have invested in-and thus increased-the apparent value of the patented technologies, and because our damages rules do not give sufficient weight to the contributions made to the defendant's sales by technologies and product features not covered by the patent in suit. ${ }^{235}$ Recent changes have improved the law in this respect, ${ }^{236}$ but more remains to be done. ${ }^{237}$ Meanwhile, the postjudgment ongoing royalty law is getting worse, as the Federal Circuit increasingly seems to regard it as a means to punish infringement that is not enjoined, rather than as a

232. A less restrictive alternative would be to grant injunctive relief but delay its implementation, allowing an infringer to design around a minor patent if possible. See Chien \& Lemley, supra note 27, at 34-36 (arguing for delay in implementation of ITC exclusion orders); Lemley \& Shapiro, Patent Holdup, supra note 101, at 2038 (suggesting guidelines for injunction delay). Whether this will work depends on the ease of finding an alternative (which is properly related to the value of the patent) and the ease of switching to that alternative after the fact (which is not). Where implementing an alternative is difficult or very costly, even temporarily staying the injunction will not avoid the leverage the injunction or threat thereof gives to the patent holder to negotiate a royalty in excess of the ex ante value of the patent.

233. For discussion of ITC exclusion orders and the holdup problem, see Chien \& Lemley, supra note 27, at 19-28. For arguments that this policy should change, see U.S. Dep't of Justice \& U.S. PTO, Policy Statement on Remedies for Standards-Essential Patents Subject to Voluntary F/RAND Commitments 9-10 (2013), available at http://www.justice.gov/atr/public/guidelines/290994.pdf (on file with the Columbia Law Review); Chien \& Lemley, supra note 27, at 28-44. The 2013 decision by the White House to veto an ITC exclusion order based on a standard-essential patent may suggest some limits to the power of the ITC to grant injunctions. Letter from Michael B. G. Froman, U.S. Trade Representative, Exec. Office of the President, to Irving A. Williamson, Chairman, U.S. Int'l Trade Comm'n (Aug. 3, 2013), available at http:/ /www.scribd.com/ doc/157894184/13-08-03-USTR-Letter-Vetoing-ITC-794-Exclusion-Order (on file with the Columbia Law Review).

234. See Lemley \& Shapiro, Patent Holdup, supra note 101, at 2035-39 (suggesting restricting injunctions in cases where lost profits are unavailable would reduce holdup problem).

235. Lemley, Distinguishing Lost Profits, supra note 100, at 663 (noting other patents besides one at issue contribute to defendant's product).

236. See, e.g., Uniloc USA, Inc. v. Microsoft Corp., 632 F.3d 1292, 1318 (Fed. Cir. 2011) (holding entire market value of accused product is basis for damages only when patented feature is reason for consumer demand); Lucent Techs., Inc. v. Gateway, Inc., 580 F.3d 1301, 1332-33 (Fed. Cir. 2009) (accounting for nonpatent factors while assessing value of product).

237. See, e.g., Durie \& Lemley, supra note 113, at 636-44 (suggesting simplified factors to consider in structuring royalties). 
means of compensating a patentee for continued use of the patented technology. ${ }^{238}$ The ability of patent holders to extract excessive damages awards is also a principal source of the costs that can result from dispersion or disaggregation of complementary patents, and adds to the incentives for bottom feeding and litigation abuse. ${ }^{239}$

Put differently, under current law, patent holders can claim as reasonable royalties an excessive share of the value of the product that includes, and the value of which is attributable to, both the patented technology and other components. Patent asserters-practicing entities and trolls alike-recognize this attribute of current damages law and thus commonly bypass the component suppliers and, instead, target downstream entities selling more costly finished products, even when the patented technology is contained entirely within the component. One step that might ameliorate the damages problem somewhat would be to insist that damages be calculated with reference to the smallest saleable component that incorporates the patented technology. ${ }^{240}$ The value of that unit is less than that of the larger products of which it is only a part and is thus closer to the actual value contributed by the patented technology. Such a requirement would not, however, be a complete solution because even component products typically incorporate many different inventions. No one buys circuit layouts, for instance; companies buy semiconductor chips that package those layouts together with many different inventions. ${ }^{241}$

Third, the high cost and uncertainty of litigation encourages bottom-feeder suits aimed at settlement rather than at winning. These bottom feeders are mostly trolls, ${ }^{242}$ though there are some nuisance suits filed by practicing entities as well. It is hard to see any social benefit

238. E.g., ActiveVideo Networks, Inc. v. Verizon Commc'ns, Inc., 694 F.3d 1312, 1339-40 (Fed. Cir. 2012) (finding ongoing royalty should exceed past damages necessary to compensate plaintiff); Amado v. Microsoft Corp., 517 F.3d 1353, 1361-62 (Fed. Cir. 2008) (same); Paice LLC v. Toyota Motor Corp., 609 F. Supp. 2d 620, 625, 630-31 (E.D. Tex. 2009) (awarding royalty of $\$ 98$ per unit after Federal Circuit reversed earlier award of \$25 per unit). For criticism, see Mark A. Lemley, The Ongoing Confusion over Ongoing Royalties, 76 Mo. L. Rev. 695, 700-08 (2011), which explains the error of these cases and suggests that reasonable royalties should be the same before and after trial.

239. See supra notes 182-184 (discussing harms of patent disaggregation).

240. See Eric Phillips \& David Boag, Recent Rulings on the Entire Market Value Rule and Impacts on Patent Litigation and Valuation, 48 les Nouvelles 1, 4-6 (2013) (discussing smallest saleable component standard for royalties).

241. In theory, there is another potential problem: The price at which the smallest saleable unit is sold is likely to have been determined without regard to the cost of a license for patents not previously asserted; that price might have been higher had the patent been taken into account. As a practical matter, however, that is unlikely to make much difference in an industry in which many different patents read on any given technology; except in rare cases, no one patent should make much difference to the price of the product.

242. For discussion of bottom-feeder trolls, see supra notes 44-46 and accompanying text. 
served by bottom-feeder nuisance suits or by the related practice of targeting end users with small-damages threats rather than litigating against the upstream manufacturer. The law should do more to discourage frivolous suits or those driven by the expectation that the cost of litigation will drive defendants to settle even when faced with unmeritorious claims. Efforts to reduce litigation discovery costs are a start; if litigation is less costly, bottom feeders have less room to make money.

Fee shifting is another possibility. Current Federal Circuit law makes it virtually impossible for defendants to recover their fees unless the patent holder committed inequitable conduct, ${ }^{243}$ which a defendant is rarely able to prove under current Federal Circuit law. ${ }^{244}$ By contrast, courts are permitted in their discretion to award fees to prevailing parties in some circumstances in copyright and trademark cases. ${ }^{245}$ Courts might interpret patent law more generously, to follow the copyright and trademark model. ${ }^{246}$ Alternatively, the SHIELD Act pending in Congress would provide for fee shifting in some circumstances, though as currently written it would apply only to litigation of patents acquired, by trolls or by practicing entities that do not practice the patents, in certain types of secondary market transactions. ${ }^{247}$ While passage of the SHIELD Act as presently drafted would be preferable to no reform, the legislation might be more valuable if it were focused on specific conduct or the

243. See, e.g., Wedgetail, Ltd. v. Huddleston Deluxe, Inc., 576 F.3d 1302, 1304 (Fed. Cir. 2009) (noting only "limited universe of circumstances," including inequitable conduct before PTO, warrants fee shifting).

244. See Therasense, Inc. v. Becton, Dickinson \& Co., 649 F.3d 1276, 1291-93 (Fed. Cir. 2011) (en banc) (raising standard for inequitable conduct to make proof of inequitable conduct more difficult); see also Robert D. Swanson, The Exergen and Therasense Effects 33-34 (May 30, 2013) (unpublished manuscript), available at http://papers.ssrn.com/ abstract=2271837 (on file with the Columbia Law Review) (demonstrating inequitable conduct is rarely pled or proven after Therasense).

245. See, e.g., Fogerty v. Fantasy, Inc., 510 U.S. 517, 534 (1994) (requiring prevailing plaintiffs and defendants be treated alike for awarding attorneys' fees under Copyright Act, which is at court's discretion); Door Sys., Inc. v. Pro-Line Door Sys., Inc., 126 F.3d 1028, 1031 (7th Cir. 1997) (setting standard for fee shifting under Lanham Act); Hartman v. Hallmark Cards, Inc., 833 F.2d 117, 123-24 (8th Cir. 1987) (same).

246. The Supreme Court recently granted certiorari in two cases that might give it the opportunity to bring the patent standard in line with the copyright and trademark model. See Icon Health \& Fitness, Inc. v. Octane Fitness, LLC, 496 F. App'x 57 (Fed. Cir. 2012), cert. granted, 81 U.S.L.W. 3567 (U.S. Oct. 1, 2013) (No. 12-1184); Highmark, Inc. v. Allcare Health Mgmt. Sys., Inc., 687 F.3d 1300 (Fed. Cir. 2012), cert. granted, 81 U.S.L.W. 3562 (U.S. Oct. 1, 2013) (No. 12-1163).

247. Saving High-Tech Innovators from Egregious Legal Disputes Act of 2013 (SHIELD Act), H.R. 845, 113th Cong. (2013). As currently drafted, the legislation would provide for fee shifting when a patent is found invalid or not infringed and the patent holder is (1) not the original inventor or the original assignee of the patent, (2) has not practiced the patent, and (3) is not a university or a technology transfer organization the primary purpose of which is to facilitate commercialization of university patents. Id. $\S 2$. 
assertion of weak patents, rather than on the provenance of the asserted patents and who is doing the asserting. ${ }^{248}$

Beyond fee shifting, it would be useful to consider other remedies for abusive conduct by patent holders. Such conduct includes abusive prelitigation patent assertions, ${ }^{249}$ and engaging in "submarine patent" tactics by concealing patent positions and deliberately refraining from asserting patents until the patent holder has become locked into the allegedly patented technology. ${ }^{250}$

Finally, agencies, courts, and scholars should rethink their approach to aggregation of patents. Disaggregation of complementary patents can result in higher costs to technology users, even apart from transaction costs, because of the double marginalization/Cournot complements problem. ${ }^{251}$ In an ideal world, this would not be true. But as we have seen, patent damages law is flawed, and patent holders are able to obtain damages awards, and thus royalties and settlements negotiated in the shadow of damages awards, in excess of the ex ante incremental value of the patented technology. Given the flaws in damages law, double marginalization is a straightforward market failure, one with competitive consequences.

Antitrust law has traditionally worried about concentration of power. Section 7 of the Clayton Act ${ }^{252}$ has accordingly been interpreted to prevent the acquisition of too many patent rights from others, just as it restricts the acquisition of companies and other assets. ${ }^{253}$ But our analysis suggests that, in the IT industry, antitrust law should worry less about the acquisition of patents and more about their disaggregation. In the pharmaceutical industry, it is easy to imagine one firm buying patents covering all the competing drugs for a particular disease. A comparable cornering of an otherwise competitive technology market seems much

248. As a general matter, the prospect of bilateral fee shifting should tend to increase the value of patents that are likely to be valid and infringed, by enabling the patent holder to recover fees as well as damages, and to decrease the value of weaker patents, by reducing the risks facing alleged infringers. On the complex effects of fee shifting statutes, see Colleen V. Chien, Reforming Software Patents, 50 Hous. L. Rev. 325, 369-85 (2012) (examining whether fee shifting deters frivolous lawsuits).

249. See supra Part II.B.4 (discussing aggressive patent assertion tactics).

250. On submarine patenting, see, for example, Mark A. Lemley \& Kimberly A. Moore, Ending Abuse of Patent Continuations, 84 B.U. L. Rev. 63, 79-80 (2004), which explains how some patentees delay issuance of patents in order to surprise the industry.

251. See supra notes 173-180 and accompanying text (describing Cournot complements problem and other issues resulting from patent disaggregation).

252. 15 U.S.C. $\$ 18$ (2012).

253. See Hovenkamp et al., supra note $157, \S 14-2 \mathrm{~B}$, at $14-7$ to $14-8$ (noting courts have held or assumed intellectual property is "asset" subject to Clayton Act). By contrast, the development of a patent portfolio through internal invention is considered outside the scope of the antitrust laws. Automatic Radio Mfg. Co. v. Hazeltine Research, Inc., 339 U.S. 827, 834-36 (1950) ("The mere accumulation of patents, no matter how many, is not in and of itself illegal."). 
less likely in the IT industry. But disaggregation of patents, including privateering to entities like Rockstar Bidco, MOSAID, and Acacia, and transfers to practicing entities that do not already own large blocks of patents that are complements to the acquired patents, can exacerbate the royalty stacking problem and can be used to raise rivals' costs. ${ }^{254}$

Disaggregation does not fit easily into an antitrust framework centered on market concentration, and no antitrust cases have condemned it. Nevertheless, we see three possible forms of antitrust limits. First, agreements to sell or disperse patents that seem likely to create or exacerbate a double marginalization problem could be challenged under both sections 1 and 2 of the Sherman Act $^{255}$ and section 7 of the Clayton Act, ${ }^{256}$ especially if one or more of the entities involved is likely to have strategic incentives to impose costs on rivals. ${ }^{257}$ The price effect of such a scheme might be especially clear when patents are sold to evade a FRAND licensing obligation. ${ }^{258}$ Second, in appropriate circumstances antitrust agencies can condition approval of mergers or other consent decree settlements on an agreement not to engage in privateering. Finally, the law might be revised to require disclosure of privateering

254. For a fuller discussion of the antitrust issues presented by privateering, see generally Mark S. Popofsky \& Michael D. Laufert, Patent Assertion Entities and Antitrust: Operating Company Patent Transfers, Antitrust Source, April 2013, at 1, available at http://www.americanbar.org/content/dam/aba/publishing/antitrust_source/apr13_full _source.authcheckdam.pdf\#page=25 (on file with the Columbia Law Review) (pointing out concerns in privateering regarding, among others, evading FRAND commitments and raising rivals' costs).

255. Sherman Act $§ \S 1-2,15$ U.S.C. $§ \S 1-2$.

256. See Popofsky \& Laufert, supra note 254, at 10-12 (discussing how Clayton Act and Sherman Act could constrain practicing entities' transfer of their patents to trolls). For a more skeptical view, see Orr, supra note 200, at 554-67 (suggesting antitrust can help restrain anticompetitve behavior but that reach is constrained by patent law).

257. Proof that the transaction is likely to result in increased patent royalties might not be sufficient for an antitrust claim unless that effect can be linked to harm to competition in a properly defined antitrust market. See Rambus, Inc. v FTC, 522 F.3d 456, 465-67 (D.C. Cir. 2008) (finding patentee's avoidance of contractual constraint on pricing insufficient to establish injury to competition). An antitrust violation might be established, however, if the disaggregation is likely to increase costs to rivals of one or both of the parties to the transaction or their customers and thereby to injure competition in a downstream market in which the technologies claimed by the affected patents are used, or if the disaggregation is likely to increase the ability of the parties to the transaction to "double dip" into likely excessive royalties available to patent holders and thus to increase their market power in one or more technology markets in which the patents are licensed. See supra notes 182-184 and accompanying text (explaining "double dipping" concept).

258. The avoidance of FRAND obligations was arguably behind the transfer of patents from Nokia to MOSAID, for instance. See David Balto, Using the Antitrust Laws to Police Patent Privateering, Patently-O Blog (June 3, 2013, 11:30 AM), http://www.patent lyo.com/patent/2013/06/guest-post-on-using-the-antitrust-laws-to-police-patentprivateering.html (on file with the Columbia Law Review) (arguing Nokia transfer to MOSAID raised numerous antitrust concerns); see also Lemley \& Shapiro, A Simple Approach, supra note 108 (manuscript at 18-20, 23-24) (arguing FRAND commitments should bind transferees and discussing antitrust limits on transfers to evade FRAND). 
agreements so that sham transactions or other arrangements in which the seller retains effective control over who can be sued can be detected and hopefully deterred.

None of these solutions is perfect, and anticompetitive patent dispersion might be here to stay. Like trolls, it is a symptom of broader problems with the patent system. But it is also evidence that the problem cannot be solved simply by focusing on some bad actors, the trolls.

\section{CONCLUSION}

Patent trolls are taking the rap for problems with the patent system. That is not to say trolls are not a problem; they are a large and growing one. But they are not the problem. Rather, they are a symptom of systemic issues the patent system faces in the IT industry-too many patents interpreted too broadly, a remedy system that routinely awards excessive damages and enables patent holders to bargain for excessively costly settlements, and an enormous royalty stacking problem. Practicing entities, as well as trolls, can and do take advantage of these issues. Rather than focusing on the trolls-the symptoms-the law should turn its attention to the disease itself. 


\section{SELECTED BIBLIOGRAPHY}

Abramowicz, Michael, The Danger of Underdeveloped Patent Prospects, 92 Cornell L. Rev. 1065 (2007).

Abramowicz, Michael \& John F. Duffy, Intellectual Property for Market Experimentation, 83 N.Y.U. L. Rev. 337 (2008).

Allison, John R. \& Mark A. Lemley, Empirical Evidence on the Validity of Litigated Patents, 26 AIPLA Q.J. 185 (1998).

Allison, John R., et al., Extreme Value or Trolls on Top? The Characteristics of the Most-Litigated Patents, 158 U. Pa. L. Rev. 1 (2009).

Allison, John R., et al., Patent Litigation and the Internet, Stan. Tech. L. Rev., Feb. 14, 2012, at 1, http://stlr.stanford.edu/pdf/allisonpatent-litigation.pdf.

Allison, John R., et al., Patent Quality and Settlement Among Repeat Patent Litigants, 99 Geo. L.J. 677 (2011).

Bessen, James \& Michael J. Meurer, The Direct Costs from NPE Disputes, 99 Cornell L. Rev. (forthcoming 2014), available at http://www.bu.edu/law/faculty/scholarship/workingpapers/do cuments/BessenJ-MeurerM062512revised7-2013.pdf.

Bessen, James \& Michael J. Meurer, Patent Failure: How Judges, Bureaucrats, and Lawyers Put Innovators at Risk (2008).

Bessen, James, et al., The Private and Social Costs of Patent Trolls (Bos. Univ. Sch. of Law Working Paper No. 11-45, 2011), available at http://ssrn.com/abstract=1930272.

Bresnahan, Timothy F. \& Peter C. Reiss, Dealer and Manufacturer Margins, 16 RAND J. Econ. 253 (1985).

Burk, Dan L. \& Mark A. Lemley, Is Patent Law Technology-Specific?, 17 Berkeley Tech. L.J. 1155 (2002).

Burk, Dan L. \& Mark A. Lemley, The Patent Crisis and How the Courts Can Solve It (2009).

Burk, Dan L. \& Mark A. Lemley, Policy Levers in Patent Law, 89 Va. L. Rev. 1575 (2003).

Calabresi, Guido \& A. Douglas Melamed, Property Rules, Liability Rules, and Inalienability: One View of the Cathedral, 85 Harv. L. Rev. 1089 (1972). 
Chandy, Rajesh K. \& Gerard J. Tellis, The Incumbent's Curse? Incumbency, Size, and Radical Product Innovation, J. Marketing, July 2000 , at 1 .

Chapman, Gretchen B. \& Brian H. Bornstein, The More You Ask for, the More You Get: Anchoring in Personal Injury Verdicts, 10 Applied Cognitive Psychol. 519 (1996).

Chapman, Gretchen B. \& Eric J. Johnson, Incorporating the Irrelevant: Anchors in Judgments of Belief and Value, in Heuristics and Biases: The Psychology of Intuitive Judgment 120 (Thomas Gilovich, Dale Griffin \& Daniel Kahneman eds., 2002).

Chien, Colleen, Patent Trolls by the Numbers (Santa Clara Univ. Sch. of Law, Legal Studies Research Paper No. 08-13, 2013), available at http:/ / papers.ssrn.com/abstract=2233041.

Chien, Colleen, PowerPoint: NPEs in the Northern District of California (2012).

Chien, Colleen V., From Arms Race to Marketplace: The Complex Patent Ecosystem and Its Implications for the Patent System, 62 Hastings L.J. 297 (2010).

Chien, Colleen V., Of Trolls, Davids, Goliaths, and Kings: Narratives and Evidence in the Litigation of High-Tech Patents, 87 N.C. L. Rev. 1571 (2009).

Chien, Colleen V., Startups and Patent Trolls, 17 Stan. Tech. L. Rev. (forthcoming 2014), available at http://papers.ssrn.com/ abstract $=2146251$.

Chien, Colleen V. \& Michael J. Guo, Does the U.S. Patent System Need a Patent Small Claims Proceeding? (Santa Clara Univ. Sch. of Law, Legal Studies Research Paper No. 10-13, 2013), available at http:/ / papers.ssrn.com/abstract=2249896.

Chien, Colleen V. \& Aashish R. Karkhanis, Functional Claiming and Software Patents (Santa Clara Univ. Sch. of Law, Legal Studies Research Paper No. 06-13, 2013), available at http://papers. ssrn.com/abstract=2215867.

Chien, Colleen V. \& Mark A. Lemley, Patent Holdup, the ITC, and the Public Interest, 98 Cornell L. Rev. 1 (2012).

Cotropia, Christopher A., The Folly of Early Filing in Patent Law, 61 Hastings L.J. 65 (2009). 
Cotropia, Christopher A. \& Mark A. Lemley, Copying in Patent Law, 87 N.C. L. Rev. 1421 (2009).

Cournot, Augustin, Researches into the Mathematical Principles of the Theory of Wealth (Nathaniel T. Bacon trans., Augustus M. Kelley Publishers 1971) (1838).

Durie, Daralyn J. \& Mark A. Lemley, A Structured Approach to Calculating Reasonable Royalties, 14 Lewis \& Clark L. Rev. 627 (2010).

Easterbrook, Frank H. \& Daniel R. Fischel, Close Corporations and Agency Costs, 38 Stan. L. Rev. 271 (1986).

Englich, Birte, Thomas Mussweiler \& Fritz Strack, The Last Word in Court-A Hidden Disadvantage for the Defense, 29 Law \& Hum. Behav. 705 (2005).

Ewing, Tom, Indirect Exploitation of Intellectual Property Rights by Corporations and Investors, Hastings Sci. \& Tech. L.J., Winter 2012, at 1.

Ewing, Tom \& Robin Feldman, The Giants Among Us, Stan. Tech. L. Rev., Jan. 9, 2012, at 1, http://stlr.stanford.edu/pdf/feldmangiants-among-us.pdf.

Exec. Office of the President, Patent Assertion and U.S. Innovation (2013), available at http://www.whitehouse.gov/sites/default/ files/docs/patent_report.pdf.

Farrell, Joseph, et al., Standard Setting, Patents, and Hold-Up, 74 Antitrust L.J. 603 (2007).

Feldman, Robin, Tom Ewing \& Sara Jeruss, The AIA 500 Expanded: The Effects of Patent Monetization Entities, 18 UCLA J.L. \& Tech. (forthcoming 2013), available at http://ssrn.com/abstract= 2247195.

FTC, The Evolving IP Marketplace: Aligning Patent Notice and Remedies with Competition (2011), available at http://www.ftc.gov/os/ 2011/03/110307patentreport.pdf.

Galasso, Alberto \& Mark Schankerman, Patent Thickets, Courts, and the Market for Innovation, 41 RAND J. Econ. 472 (2010).

Gergen, Mark P., et al., The Supreme Court's Accidental Revolution? The Test for Permanent Injunctions, 112 Colum. L. Rev. 203 (2012). 
Gilbert, Richard J., Deal or No Deal? Licensing Negotiations in StandardSetting Organizations, 77 Antitrust L.J. 855 (2011).

Golden, John M., Commentary, "Patent Trolls" and Patent Remedies, 85 Tex. L. Rev. 2111 (2007).

Graham, Stuart J.H., et al., High Technology Entrepreneurs and the Patent System: Results of the 2008 Berkeley Patent Survey, 24 Berkeley Tech. L.J. 1255 (2009).

Hagiu, Andrei \& David B. Yoffie, The New Patent Intermediaries: Platforms, Defensive Aggregators, and Super-Aggregators, J. Econ. Persp., Winter 2013, at 45.

Heller, Michael A. \& Rebecca S. Eisenberg, Can Patents Deter Innovation? The Anticommons in Biomedical Research, 280 Science 698 (1998).

Heller, Michael A., The Tragedy of the Anticommons: Property in the Transition from Marx to Markets, 111 Harv. L. Rev. 621 (1998).

Hovenkamp, Erik, Predatory Patent Litigation (Aug. 5, 2013) (unpublished manuscript), available at http://papers.ssrn.com/ abstract=2308115.

Hovenkamp, Herbert, Antitrust and the Movement of Technology, 19 Geo. Mason L. Rev. 1119 (2012).

Jaffe, Adam B. and Josh Lerner, Innovation and Its Discontents (2004).

Katz, Ariel, Making Sense of Nonsense: Intellectual Property, Antitrust, and Market Power, 49 Ariz. L. Rev. 837 (2007).

Kieff, F. Scott, Property Rights and Property Rules for Commercializing Inventions, 85 Minn. L. Rev. 697 (2001).

Kitch, Edmund W., The Nature and Function of the Patent System, 20 J.L. \& Econ. 265 (1977).

Krattenmaker, Thomas G. \& Steven C. Salop, Anticompetitive Exclusion: Raising Rivals' Costs to Achieve Power over Price, 96 Yale L.J. 209 (1986).

Layne-Farrar, Anne, The Brothers Grimm Book of Business Models: A Survey of Literature and Developments in Patent Acquisition and Litigation (Mar. 21, 2012) (unpublished manuscript), available at http://ssrn.com/abstract=2030323. 
Lemley, Mark A., Are Universities Patent Trolls?, 18 Fordham Intell. Prop. Media \& Ent. L.J. 611 (2008).

Lemley, Mark A., Distinguishing Lost Profits from Reasonable Royalties, 51 Wm. \& Mary L. Rev. 655 (2009).

Lemley, Mark A., The Economics of Improvement in Intellectual Property Law, 75 Tex. L. Rev. 989 (1997).

Lemley, Mark A., Ex Ante Versus Ex Post Justifications for Intellectual Property, 71 U. Chi. L. Rev. 129 (2004).

Lemley, Mark A., Fixing the Patent Office, 13 Innovation Pol'y \& Econ. 83 (2013).

Lemley, Mark A., Ignoring Patents, 2008 Mich. St. L. Rev. 19.

Lemley, Mark A., The Myth of the Sole Inventor, 110 Mich. L. Rev. 709 (2012).

Lemley, Mark A., The Ongoing Confusion over Ongoing Royalties, 76 Mo. L. Rev. 695 (2011).

Lemley, Mark A., Rational Ignorance at the Patent Office, 95 Nw. U. L. Rev. 1495 (2001).

Lemley, Mark A., Should Patent Infringement Require Proof of Copying?, 105 Mich. L. Rev. 1525 (2007).

Lemley, Mark A., Software Patents and the Return of Functional Claiming, 2013 Wis. L. Rev. (forthcoming), available at http://papers.ssrn.com/abstract=2117302.

Lemley, Mark A. \& Mark P. McKenna, Is Pepsi Really a Substitute for Coke? Market Definition in Antitrust and IP, 100 Geo. L.J. 2055 (2012).

Lemley, Mark A. \& Kimberly A. Moore, Ending Abuse of Patent Continuations, 84 B.U. L. Rev. 63 (2004).

Lemley, Mark A. \& Bhaven Sampat, Is the Patent Office a Rubber Stamp?, 58 Emory L.J. 181 (2008).

Lemley, Mark A. \& Carl Shapiro, Patent Holdup and Royalty Stacking, 85 Tex. L. Rev. 1991 (2007).

Lemley, Mark A. \& Carl Shapiro, A Simple Approach to Setting Reasonable Royalties for Standard-Essential Patents, 28 Berkeley Tech. L.J. (forthcoming 2013). 
Lemley, Mark A., et al., Rush to Judgment? Trial Length and Outcomes in Patent Cases, 41 AIPLA Q.J. 169 (2013).

Leslie, Christopher R., Patents of Damocles, 83 Ind. L.J. 133 (2008).

Lichtman, Doug, Understanding the RAND Commitment, 47 Hous. L. Rev. 1023 (2010).

Love, Brian J., The Misuse of Reasonable Royalty Damages as a Patent Infringement Deterrent, 74 Mo. L. Rev. 909 (2009).

Love, Brian J., Note, Patentee Overcompensation and the Entire Market Value Rule, 60 Stan. L. Rev. 263 (2007).

Magliocca, Gerard N., Blackberries and Barnyards: Patent Trolls and the Perils of Innovation, 82 Notre Dame L. Rev. 1809 (2007).

Maurer, Stephen M. \& Suzanne Scotchmer, The Independent Invention Defence in Intellectual Property, 69 Economica 535 (2002).

McDonough, James F., III, Comment, The Myth of the Patent Troll: An Alternative View of the Function of Patent Dealers in an Idea Economy, 56 Emory L.J. 189 (2006).

Merges, Robert P., The Trouble with Trolls: Innovation, Rent-Seeking, and Patent Law Reform, 24 Berkeley Tech. L.J. 1583 (2009).

Miller, Joseph Scott, Standard Setting, Patents, and Access Lock-In: RAND Licensing and the Theory of the Firm, 40 Ind. L. Rev. 351 (2007).

Miller, Shawn P., Patent "Trolls": Rent-Seeking Parasites or InnovationFacilitating Middlemen? (Apr. 26, 2010) (unpublished manuscript), available at http://papers.ssrn.com/abstract= 1885538.

Miller, Shawn P., What's the Connection Between Repeat Litigation and Patent Quality? A (Partial) Defense of the Most Litigated Patents, 16 Stan. Tech. L. Rev. 313 (2013), http://stlr.stanford.edu/ pdf/mostlitigatedpatents.pdf.

Milton, Hal, "Improvements" in Patent Licenses: Presumptions and Clauses Derived from Case Law, 34 AIPLA Q.J. 333 (2006).

Moore, Kimberly A., Populism and Patents, 82 N.Y.U. L. Rev. 69 (2007).

Nguyen, Xuan-Thao, Patent Prudential Standing, 21 Geo. Mason L. Rev. (forthcoming 2013), available at http://papers.ssrn.com/sol3/ papers.cfm?abstract_id=2321808. 
Olson, David S., Removing the Troll from the Thicket: The Case for Enhancing Patent Maintenance Fees in Relation to the Size of a Patent Owner's Non-Practiced Patent Portfolio (Bos. Coll. Law Sch., Legal Studies Research Paper No. 303, 2013), available at http:/ /ssrn.com/abstract=2318521.

Parchomovsky, Gideon \& R. Polk Wagner, Patent Portfolios, 154 U. Pa. L. Rev. 1 (2005).

Patterson, Mark R., Commentary, Antitrust and the Costs of StandardSetting: A Commentary on Teece \& Sherry, 87 Minn. L. Rev. 1995 (2003).

Patterson, Mark R., Inventions, Industry Standards, and Intellectual Property, 17 Berkeley Tech. L.J. 1043 (2002).

Patterson, Mark R., Leveraging Information About Patents: Settlements, Portfolios, and Holdups, 50 Hous. L. Rev. 483 (2012).

Phillips, Eric \& David Boag, Recent Rulings on the Entire Market Value Rule and Impacts on Patent Litigation and Valuation, 48 les Nouvelles 1 (2013).

Popofsky, Mark S. \& Michael D. Laufert, Patent Assertion Entities and Antitrust: Operating Company Patent Transfers, Antitrust Source, April 2013, at 1, available at http://www.american bar.org/content/dam/aba/publishing/antitrust_source/apr13_ full_source.authcheckdam.pdf\#page=25.

Risch, Michael, Patent Portfolios as Securities, 63 Duke L.J. 89 (2013).

Risch, Michael, Patent Troll Myths, 42 Seton Hall L. Rev. 457 (2012).

Rivette, Kevin G. \& David Kline, Rembrandts in the Attic: Unlocking the Hidden Value of Patents (2000).

Schwartz, David L. \& Jay P. Kesan, Analyzing the Role of Non-Practicing Entities in the Patent System, 99 Cornell L. Rev. (forthcoming 2014), available at http:// papers.ssrn.com/abstract $=2117421$.

Schwartz, David L., The Rise of Contingent Fee Representation in Patent Litigation, 64 Ala. L. Rev. 335 (2012).

Shapiro, Carl, Navigating the Patent Thicket: Cross Licenses, Patent Pools, and Standard Setting, in 1 Nat'l Bureau of Econ. Research, Innovation Policy and the Economy 119 (Adam B. Jaffe et al. eds., 2001). 
Shapiro, Carl, Prior User Rights, 96 Am. Econ. Rev. 92 (2006).

Sichelman, Ted, Commercializing Patents, 62 Stan. L. Rev. 341 (2010).

Sichelman, Ted, Purging Patent Law of 'Private Law' Remedies, 92 Tex. L. Rev. (forthcoming 2014), available at http://papers.ssrn.com/ abstract $=1932834$.

Sichelman, Ted, The Vonage Trilogy: A Case Study in "Patent Bullying," in Perspectives on Patentable Subject Matter (Michael Abramowicz et al. eds., forthcoming 2013), available at http:// papers.ssrn.com/abstract $=1856703$.

Swanson, Robert D., The Exergen and Therasense Effects (May 30, 2013) (unpublished manuscript), available at http://papers.ssrn.com/ abstract $=2271837$.

Torrance, Andrew W. \& Bill Tomlinson, Property Rules, Liability Rules, and Patents: One Experimental View of the Cathedral, 14 Yale J.L. \& Tech. 138 (2011)

Tucker, Catherine, Patent Trolls and Technology Diffusion (Mar. 26, 2013) (unpublished manuscript), available at http://ssrn.com/ abstract $=1976593$.

Tversky, Amos \& Daniel Kahneman, Loss Aversion in Riskless Choice: A Reference-Dependent Model, 106 Q.J. Econ. 1039 (1991).

U.S. Dep't of Justice \& U.S. Patent \& Trademark Office, Policy Statement on Remedies for Standards-Essential Patents Subject to Voluntary F/RAND Commitments (2013), available at http://www.justice .gov/atr/public/guidelines/290994.pdf.

U.S. Gov't Accountability Office, GAO-13-465, Intellectual Property: Assessing Factors That Affect Patent Infringement Litigation Could Improve Patent Quality (2013), available at http://www. gao.gov/assets/660/657103.pdf.

Usselman, Steven W., Regulating Railroad Innovation: Business, Technology, and Politics in America, 1840-1920 (2002).

Vermont, Samson, Independent Invention as a Defense to Patent Infringement, 105 Mich. L. Rev. 475 (2006).

Wilson, Kelce S. \& Claudia Tapia Garcia, The Three Classes of Patent Usage, 46 les Nouvelles 283 (2011). 
Wilson, Kelce, The Four Phases of Patent Usage, 40 Cap. U. L. Rev. 679 (2012). 
